\title{
Microwave-Promoted Morita-Baylis-Hillman Reactions: Efficient Synthesis of New Monoacylglycerols (MAGs) as Potential Anti-Parasitic Compounds
}

\author{
Suervy C. O. Sousa, Claudio G. L. Junior, Fábio P. L. Silva, Natália G. Andrade, \\ Ticiano P. Barbosa and Mário L. A. A. Vasconcellos* \\ Departamento de Química, Universidade Federal da Paraíba, Campus I, \\ 58059-900 João Pessoa-PB, Brazil
}

\begin{abstract}
Descrevemos neste artigo, a irradiação por microondas promovendo a síntese de monoacilglicerol hidrofílico, MAG, a partir da hidrólise de um acrilato (15 min, 100\%). Depois, o MAG foi transformado em adutos de Morita-Baylis-Hillman (AMBH) hidrofílicos, (54-82\%, caminho 1). No caminho 2, outros AMBHs foram preparados em altos rendimentos (90-100\%) e transformados em AMBH hidrofílicos em 70-90\%. Durante e síntese em alta temperatura do $\mathrm{AMBH}$, foi detectado por CG-EM a formação de uma indolizina inédita. Todos estes resultados estão de acordo com o novo mecanismo unificado para a reação de Morita-Baylis-Hillman. Estes novos monoacilgliceróis, bem como seus precursores sintéticos, são novos compostos antiparasitários em potencial.
\end{abstract}

In this article we describe microwave irradiation promoting the synthesis of a hydrophilic monoacylglycerol, MAG, by hydrolysis of acrylate (15 min, 100\%). After, MAG was transformed in hydrophilic Morita-Baylis-Hillman adducts (MBHA), (54-82\%, pathway 1). In pathway 2, the different lipophilic MBHAs were prepared in high yields (90-100\%) and transformed on hydrophilic MBHA, in 70-90\%. Through the high temperature synthesis of one MBHA, a unprecedented indolizine formation was detected by GC-MS,. All results are in agreement with the new unified mechanism to the Morita-Baylis-Hillman reaction. These new monoacylglycerols, as well the its synthetic precursors, are new potential antiparasitic compounds.

Keywords: Morita-Baylis-Hillman reaction, microwaves, monoacylglycerols, acrylates, potential antiparasitic

\section{Introduction}

The Morita-Baylis-Hillman reaction (MBHR) is an important way for $\mathrm{C}-\mathrm{C}$ bond formation. ${ }^{1,2}$ It involves the alkenes coupling containing electron-withdrawing groups (EWG) with aldehyde, ketones or imines, among others. Tertiary amines are used as nucleophilic catalysts on which 1,4-diazabicyclo [2.2.2] octane (DABCO) is the most widely used (Scheme 1). The Morita-Baylis-Hillman adducts (MBHA) have been extensively used as starting materials in organic synthesis for a variety of applications, many of which have biological activity. ${ }^{2}$ An inconvenience associated with this reaction is, in several examples, the long reaction times. There are reports of reactions that, last up to 65 days. ${ }^{2}$ However, due to the synthetic utility of these MBHA adducts, several protocols have been described to
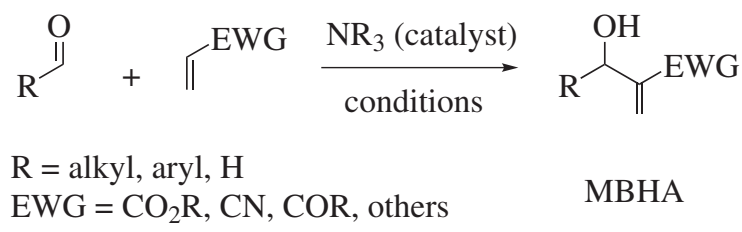

MBHA

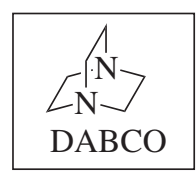

Scheme 1. The general Morita-Baylis-Hillman reactions representation. 


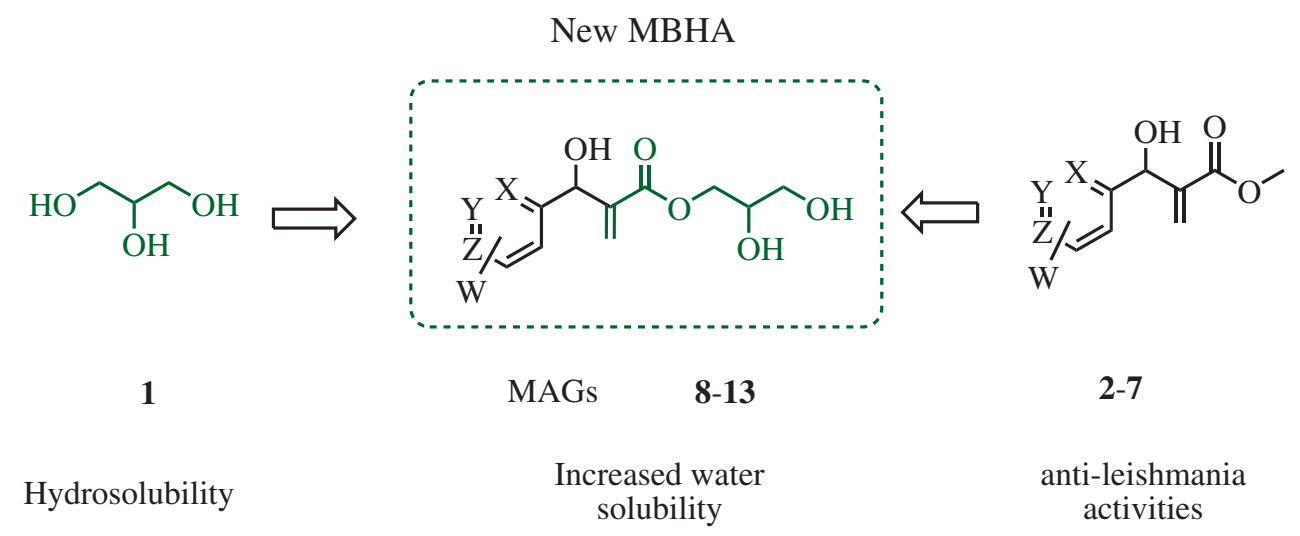

Scheme 2. 1: Glycerol; 2, 8: $\mathrm{X}=\mathrm{Y}=\mathrm{Z}=\mathrm{H}, \mathrm{W}=o$-nitro; 3, 9: $\mathrm{X}=\mathrm{Y}=\mathrm{Z}=\mathrm{H}, \mathrm{W}=m$-nitro; 4, 10: $\mathrm{X}=\mathrm{Y}=\mathrm{Z}=\mathrm{H}, \mathrm{W}=p$-nitro; $5,11: \mathrm{X}=\mathrm{N}, \mathrm{Y}=\mathrm{Z}=\mathrm{W}=\mathrm{H}$; 6, 12: $Y=N, X=Z=W=H ; 7,13: Z=N, Y=X=W=H$.

improve the reaction time and yields, such as the use of ultrasound, high pressures, use of ionic liquids, change of catalyst, change of solvents, microwaves irradiation, and several other experimental protocols. ${ }^{2}$

Despite the fact that this reaction has already more than 40 years of existence, ${ }^{1}$ the debate on the exact mechanism of reaction is still highlighted in the scientific community. The first catalytic cycle suggested by Hill and Isaacs ${ }^{3}$ is still accepted, but being the rate-determining step (RDS) it remains at the center of the scientific debate. For example, the nonprotic ${ }^{4}$ and protic ${ }^{5}$ currently accepted mechanisms suggested by McQuade and Aggarwal respectively and corroborated by Coelho ${ }^{6}$ have been very recently revisited by Cantillo and Kappe. ${ }^{7}$

In our continuing search for bioactive substances ${ }^{8}$ and in connection with our efforts towards reactivity of MBH reaction study, ${ }^{9}$ our research group described in 2006 the molluscicidal activities of simple aromatic MBHA against Biomphalaria glabrata (Say) snails, intermediate schistosomiasis host. ${ }^{10}$ In sequence, some aromatic MBHA were presented as very active compounds against the Leishmania amazonensis (cutaneous and mucocutaneous infections). ${ }^{11}$ Following that work, we published the biological evaluation of aromatic MBHA against Leishmania chagasi (visceral infections) parasites, ${ }^{12}$ and in 2010, we have shown that the MBHA 3-hydroxy-2-methylene-3-(4-nitrophenyl)propanenitrile, a high anti-leishmania compound, is also a highly active compound against epimastigote and trypomastigote form of Trypanosoma cruzi, the parasite that causes Chagas disease. ${ }^{13}$ In the same year, we presented an improved synthesis for sixteen MBHA and their biological evaluation against $L$. amazonensis and L. chagasi and we proposed, at the first time, a structure-activity relationship (SAR) analysis for this class of anti-parasitic compounds. ${ }^{14}$
In this context we present in this article the design and two efficient synthesis of new hydrophilic 8-13 monoacylglycerols (MAGs) ${ }^{15}$ (Scheme 2 and Figure 1) idealized as potential anti-parasitic compounds.

It has been reported in the literature that there is an important relationship between the hydrophilicitylipophilicity and anti-parasitic activity of drugs, e.g., it were described that increasing the solubility in water or using cationic amphiphilic drugs (CADs) tends to increase anti-leishmaniasis and anti-malarial activities. ${ }^{16}$ The strategy presented here was based on the introduction of hydrophilic portion derived from the glycerol (1), as an important factor in water solubility increase of MBHA, previously described by us as anti-leishmania proprieties ${ }^{14}$ (Figure 1). The key step in these syntheses is the MBH reaction between the commercial aldehydes 14-19 (Figure 2) and the corresponding acrylates $\mathbf{2 0}$ or $\mathbf{2 1}$ presented in Scheme 3. All MAGs steps preparations were promoted by microwave irradiations, a very efficient and green methodology ${ }^{17}$ used to obtain improvement in yields and rates of organic reactions. ${ }^{18}$

\section{Results and Discussion}

We began our experimental work on the acrylate 20 synthesis (Scheme 3). This compound was prepared by reaction between acryloyl chloride and solketal on $\mathrm{CH}_{2} \mathrm{Cl}_{2}$ at room temperature for $2 \mathrm{~h}(94 \%) .{ }^{19}$ The solketal is commercial, but it could easily be prepared here in $90 \%$ yield, by heating to $60{ }^{\circ} \mathrm{C}$ of glycerol under azeotropic distillation condition, on a mixture of acetone-pentane (1:1) under $p$-toluenesulfonic acid catalysis. ${ }^{19}$ After that, two synthetic pathways were investigated to MAGs 8-13 prepare (step iii and iv to pathway 1 and step $\mathrm{v}$ and vi to pathway 2, Scheme 3).

There are up to now, more than 280 applications to MAG 21 mainly for the polymers synthesis and other 


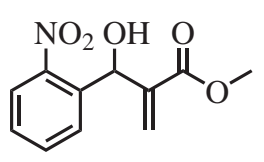

2

$\log \mathrm{P}=2.10 \pm 0.39$<smiles>C=C(C(=O)OC)C(O)c1cccc([N+](=O)[O-])c1</smiles>

3

$\log \mathrm{P}=2.10 \pm 0.39$<smiles>C=C(C(=O)OC)C(O)c1ccc([N+](=O)[O-])cc1</smiles>

4

$\log \mathrm{P}=2.10 \pm 0.39$<smiles>C=C(C(=O)OC)C(O)c1ccccn1</smiles>

5

$\log \mathrm{P}=0.87 \pm 0.38$<smiles>C=C(C(=O)OC)C(O)c1cccnc1</smiles>

6

$\log \mathrm{P}=0.87 \pm 0.38$<smiles>C=C(C(=O)OC)C(O)c1ccncc1</smiles>

7

$\log \mathrm{P}=0.87 \pm 0.38$<smiles>C=C(C(=O)OCC(O)CO)C(O)c1ccccc1[N+](=O)[O-]</smiles>

8

$\log \mathrm{P}=0.63 \pm 0.42$<smiles>C=C(C(=O)OCC(O)CO)C(O)c1cccc([N+](=O)[O-])c1</smiles>

9

$\log \mathrm{P}=0.63 \pm 0.42$<smiles>C=C(C(=O)OCC(O)CO)C(O)c1ccc([N+](=O)[O-])cc1</smiles>

10

$\log \mathrm{P}=0.63 \pm 0.42$<smiles>C=C(C(=O)OCC(O)CO)C(O)c1ccccn1</smiles>

11

$\log \mathrm{P}=-0.60 \pm 0.42$<smiles>C=C(C(=O)OCC(O)CO)C(O)c1cccnc1</smiles>

12

$\log \mathrm{P}=-0.60 \pm 0.42$<smiles>C=C(C(=O)OCC(O)CO)C(O)c1ccncc1</smiles>

13

$\log \mathrm{P}=-0.60 \pm 0.42$

Figure 1. $\log \mathrm{P}$ values were calculated in silico using the Pharma-algorithms®; help available from http://pharma-algorithms.com.<smiles>O=Cc1ccccc1[N+](=O)[O-]</smiles>

14<smiles>O=Cc1cccc([N+](=O)[O-])c1</smiles>

15<smiles>O=Cc1ccc([N+](=O)[O-])cc1</smiles>

16<smiles>O=Cc1ccccn1</smiles>

17<smiles>O=Cc1cccnc1</smiles>

18<smiles>O=Cc1ccncc1</smiles>

19

Figure 2. Commercial aldehydes 14-19 used in this article, that were also used in our previous comunications. ${ }^{11,12,14}$ 
pathway 2

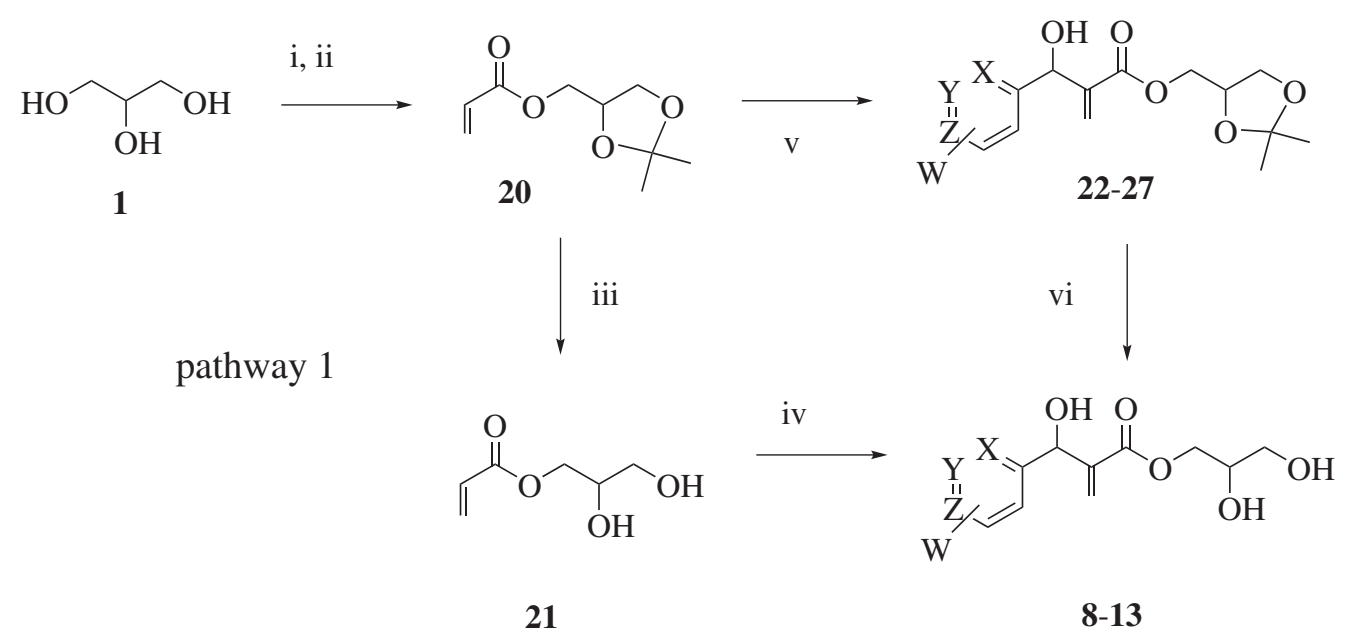

Scheme 3. i) Glycerol/acetone-pentane (1:1), $60{ }^{\circ} \mathrm{C}$, azeotropic distillation, $24 \mathrm{~h}, 95 \%$; ii) solketal, 1.2 equiv. acryloyl chloride, $\mathrm{CH}_{2} \mathrm{Cl}_{2}, \mathrm{TEA}, 94 \%$; iii) acrylate 20, amberlyst $15, \mathrm{CH}_{3} \mathrm{OH}, \mathrm{MW}, 60{ }^{\circ} \mathrm{C}, 15 \mathrm{~min}, 100 \%$; iv) aldehydes 14-19, acrylate 21, 1 equiv. DABCO, conditions in Table 2, 54-82\%; v) aldehydes 14-19, acrylate 20, 1 equiv. DABCO, conditions in Table 3, 90-100\%; vi) MBHA 22-27, condition in Table 4, 70-90\%. 22, 8: $X=Y=Z=H$, $\mathrm{W}=o$-nitro; 23, 9: $\mathrm{X}=\mathrm{Y}=\mathrm{Z}=\mathrm{H}, \mathrm{W}=m$-nitro; 24, 10: $\mathrm{X}=\mathrm{Y}=\mathrm{Z}=\mathrm{H}, \mathrm{W}=p$-nitro; 25, 11: $\mathrm{X}=\mathrm{N}, \mathrm{Y}=\mathrm{Z}=\mathrm{W}=\mathrm{H} ; 2$ 26, 12: $\mathrm{Y}=\mathrm{N}, \mathrm{X}=\mathrm{Z}=\mathrm{W}=\mathrm{H} ; 2$, 13: $\mathrm{Z}=\mathrm{N}, \mathrm{Y}=\mathrm{X}=\mathrm{W}=\mathrm{H}$.

macromolecules as nanoparticles. ${ }^{20}$ However, even that acrylates $\mathbf{2 0}$ and $\mathbf{2 1}$ are described, surprisingly, in the best of our knowledge, only in 2008, Shi and co-workers ${ }^{21}$ described a first procedure to MAG $\mathbf{2 1}$ synthesis directly from the acrylate 20. Moreover, due to high water solubility of $\mathbf{2 1}$ it is important the development of an experimental protocol to $\mathbf{2 0} \rightarrow \mathbf{2 1}$ transformation using no large amount of water or other very high boiling point polar solvent, aiming to simplify this reaction isolation. Then, the development of a more efficient technology to minimize this problem is also an important point in this present article. First, to screen the suitable reaction conditions using only water quantity for the hydrolysis reaction of $\mathbf{2 0}$ in MAG acrylate $\mathbf{2 1}$ can occur (step iii, Scheme 3), we investigated many protocols as the use of PPTS/ $\mathrm{CHCl}_{3} /$ r.t. (24 h, no reaction), ${ }^{22} \mathrm{TsOH} /$ toluene/ $80{ }^{\circ} \mathrm{C}(24 \mathrm{~h}$, no reaction $),{ }^{23} \mathrm{TsOH} / \mathrm{CH}_{3} \mathrm{OH} /$ r.t. (3 h, 34\%), ${ }^{23} \mathrm{CHCl}_{3} / \mathrm{FeCl}_{3} \cdot \mathrm{SiO}_{2} /$ r.t $(6 \mathrm{~h}, 33 \%),{ }^{24} \mathrm{HCl}$ (catalytic)/ toluene/ r.t. $(24 \mathrm{~h}, 16 \%),{ }^{25}$ montmorillonite $\mathrm{KSF} / \mathrm{CHCl}_{3} / 60^{\circ} \mathrm{C}$ (3 days, no reaction), ${ }^{26}$ montimorillonite $\mathrm{K} 10 /$ acetone/ $60{ }^{\circ} \mathrm{C}(24 \mathrm{~h}, 51 \%)^{26}$ and amberlite IRA-120/ ethanol $/ 78^{\circ} \mathrm{C}(24 \mathrm{~h}, 12 \%) \cdot{ }^{26} \mathrm{In}$ Fact, these previous results to detach this transformation difficulty appears a simple chemical processing.

After, we evaluated the use of acetic acid $10 \%$, under $60{ }^{\circ} \mathrm{C}$ (entry 1 , Table $\left.1,10 \%\right) \cdot{ }^{21}$ However, when this reaction was carried out with addition of catalytic amount of BHT as anti polymerizing compound we observed a very large increase in the reaction yield (entry 2, Table 1, 92\%). However, the use of amberlyst 15 in methanol at room temperature produced $\mathbf{2 1}$ in high yields (entry 3, Table 1,
Table 1. Conditions and results to MAG 21 preparation (Scheme 3, pathway 1 , step iii)

\begin{tabular}{llcc}
\hline entry & Condition & time & Yields / (\%)* \\
\hline 1 & Acetic acid $10 \%, 60{ }^{\circ} \mathrm{C}$ & $48 \mathrm{~h}$ & 10 \\
2 & Acetic acid $10 \%, 0.01$ equiv. BHT, $60^{\circ} \mathrm{C}$ & $24 \mathrm{~h}$ & 92 \\
3 & Amberlyst $15, \mathrm{CH}_{3} \mathrm{OH}$, r.t. & $4 \mathrm{~h}$ & 97 \\
4 & Amberlyst $15, \mathrm{CH}_{3} \mathrm{OH}, \mathrm{MW}, 60^{\circ} \mathrm{C}$ & $15 \mathrm{~min}$ & 100 \\
\hline
\end{tabular}

*Isolated pure products. The compounds purities were evaluated from GC-MS analysis.

97\%). ${ }^{27}$ Very gratifying, we discover that the $\mathbf{2 1}$ yield increased when the reaction was conducted in methanol under microwave irradiation for $15 \mathrm{~min}$ without the addition of any anti polymerization reagent. After that irradiation, a simple filtration to remove the resin and evaporation of methanol was necessary to obtained pure $\mathbf{2 1}$ in $\mathbf{1 0 0 \%}$ yields (entry 4, Table 1).

Continuing on the pathway 1 , several conditions have been evaluated on MBH reaction between the MAG acrylate 21 and aldehyde 14-19, modifying solvents (protic and nonprotic), temperature, using the microwave irradiation, trying to convert $\mathbf{2 1}$ to MBHA 8-13 (step iv, Scheme 3). Again, the experimental protocol development to $\mathbf{2 1} \rightarrow \mathbf{8 - 1 3}$ transformation without the use of large amount of water or other very high boiling point polar solvent, aiming to simplify the isolation of these reactions, especially for the more hydrophilic adducts $\mathbf{1 1}, \mathbf{1 2}$ and $\mathbf{1 3}$ (see the calculated values of $\log P$ in Figure 1). In Table 2 we present our best results for these steps iv. 
Table 2. Results of the MBHA synthesis 8-13 from step iv in Scheme 3<smiles>C=CC(=O)OCC(O)CO</smiles>

21
1 mmol DABCO

Aldehyde (14-19)

$\mathrm{MW}, 100{ }^{\circ} \mathrm{C}$

$54-81 \%$<smiles>[Y][Y4]([Y])=CC(=C)C(O)C(=O)OCC(O)CO</smiles>

8-13

\begin{tabular}{lcclcc}
\hline entry & Aldehyde & MBHA & Solvent & time / min & Yields / (\%) \\
\hline 1 & 14 & 8 & $\mathrm{CH}_{3} \mathrm{CN}$ & 10 & 68 \\
2 & 15 & 9 & $\mathrm{CH}_{3} \mathrm{CN}$ & 10 & 65 \\
3 & 16 & 10 & $\mathrm{CH}_{3} \mathrm{CN}$ & 10 & 54 \\
4 & 17 & 11 & $\mathrm{CH}_{3} \mathrm{CN}$ & 10 & 82 \\
5 & 18 & 12 & $\mathrm{CH}_{3} \mathrm{CN}$ & 10 & 81 \\
6 & 19 & 13 & $\mathrm{CH}_{3} \mathrm{CN}$ & 10 & 80 \\
\hline
\end{tabular}

*8: $\mathrm{X}=\mathrm{Y}=\mathrm{Z}=\mathrm{H}, \mathrm{W}=o$-nitro; 9: $\mathrm{X}=\mathrm{Y}=\mathrm{Z}=\mathrm{H}, \mathrm{W}=m$-nitro; 10: $\mathrm{X}=\mathrm{Y}=\mathrm{Z}=\mathrm{H}, \mathrm{W}=p$-nitro; 11: $\mathrm{X}=\mathrm{N}, \mathrm{Y}=\mathrm{Z}=\mathrm{W}=\mathrm{H} ; \mathbf{1 2}: \mathrm{Y}=\mathrm{N}, \mathrm{X}=\mathrm{Z}=\mathrm{W}=\mathrm{H}$; 13: $\mathrm{Z}=\mathrm{N}, \mathrm{Y}=\mathrm{X}=\mathrm{W}=\mathrm{H}$.

In the pathway 2, the results of MBH reaction between the less hydrophilic acrylate $\mathbf{2 0}$ and the aldehyde 14-19 (step v, Scheme 3) were more efficient when they obtained from step iv from pathway 1 , considering both reactions under microwave irradiations, producing the lipophilic MBHA 22-27 in high yields (step v, 90\%-100\% yields, Table 3). Again a complete study of different conditions was evaluated and we present in Table 3 the best results obtained for each evaluated adduct in this step. In this case, use of water or high boiling point polar solvent media does not minimize the reaction yield, since they are more lipophilic compounds.

We can point out that depending on the aldehydes used in the MBH reaction can be obtained good yields in both protic ${ }^{4,6}$ or aprotic ${ }^{5,6}$ media, confirming that slight changes in reaction conditions can change the RDS of these reactions and then, there are not, up to now, a clear general relationship between substrates-solvents-yields-rate, which corroborates the unified mechanism proposed by Cantilo and Kappe for this exquisite reaction. ${ }^{7}$

Completing the pathway 2 (step vi, Scheme 3), the synthesis of adducts 8-13 from intermediates 22-27 was first performed using the same methodology used on MAG 21 preparation (step iii, Scheme 3). However, surprisingly these transformations were inefficient, showing low yield (Table 4, entry 1). Since we observed no byproducts from this condition we have increased temperature (entry 2, Table 4). However, we obtained low yield and, in this case, byproduct. We believed that the origin of the principal byproduct could be the result from Michael reaction between the Methanol (a nucleophilic solvent) on 4-position of acrylate moiety from

Table 3. Results of the intermediates 22-27 preparations from the step v, presented in Scheme 3

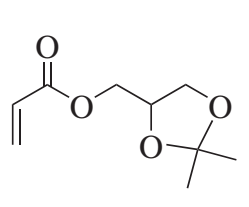

20

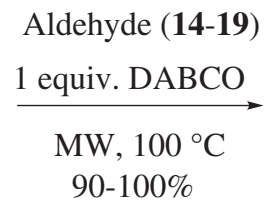

90- $100 \%$

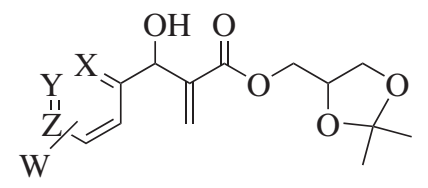

22-27

\begin{tabular}{lccccc}
\hline entry & MBHA & Aldehyde & Solvent & time / min & Yields / (\%) \\
\hline 1 & 22 & 14 & $\mathrm{DMF}$ & 10 & 100 \\
2 & 23 & 15 & $\mathrm{CH}_{3} \mathrm{CN}$ & 10 & 90 \\
3 & 24 & 16 & $\mathrm{DMF}_{\mathrm{H}} \mathrm{O}^{*}$ & 10 & 90 \\
4 & 25 & 17 & $\mathrm{CH}_{3} \mathrm{CN}$ & 10 & 98 \\
5 & 26 & 18 & $\mathrm{DMF} / \mathrm{H}_{2} \mathrm{O}^{*}$ & 10 & 95 \\
6 & 27 & 19 & $\mathrm{DMF} / \mathrm{H}_{2} \mathrm{O}^{*}$ & 10 & 90 \\
\hline
\end{tabular}

*9:1 mixture of DMF/water; 22: $\mathrm{X}=\mathrm{Y}=\mathrm{Z}=\mathrm{H}, \mathrm{W}=o$-nitro; 23: $\mathrm{X}=\mathrm{Y}=\mathrm{Z}=\mathrm{H}, \mathrm{W}=m$-nitro; 24: $\mathrm{X}=\mathrm{Y}=\mathrm{Z}=\mathrm{H}, \mathrm{W}=p$-nitro; 25: $\mathrm{X}=\mathrm{N}, \mathrm{Y}=\mathrm{Z}=\mathrm{W}=$ $\mathrm{H} ; 2$ 26: $\mathrm{Y}=\mathrm{N}, \mathrm{X}=\mathrm{Z}=\mathrm{W}=\mathrm{H} ; \mathbf{2 7}=\mathrm{Z}=\mathrm{N}, \mathrm{Y}=\mathrm{X}=\mathrm{W}=\mathrm{H}$. 


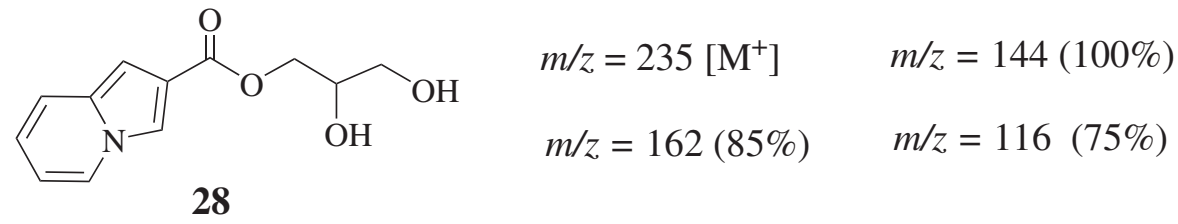

Figure 3. Indolizines 28, proposed as principal byproduct and characterized thought the expected fragmentations obtained by GC-MS.

adduct $\mathbf{2 7}$ before or along with adduct 13 production. Another hypothesis suggested by us was the possibility of MBH reaction reversibility using high temperature, according to the unified mechanism proposed by Cantillo and Kappe. ${ }^{7}$ Based on these hypothesis we first investigated the solvent change using $t$-butanol, which is less nucleophilic than methanol, not changing microwave irradiation temperature. In fact, this solvent change was efficient, producing the new hydrophilic adduct $\mathbf{1 3}$ in good yield and no byproducts was obtained (entry 3, Table 4). Continuing, this methodology was high efficient to MAGs $\mathbf{8}, \mathbf{9}$ and $\mathbf{1 0}$ preparations from MBHA 22, 23 and $\mathbf{2 4}$ (entries 4, 5 and 6, Table 4; step vi in Scheme 3). In fact, Cantillo and Kappe described that the MBH reaction between acrylates and nitroarylaldehyde are less susceptible to reversibility even when high temperatures are used (until $107^{\circ} \mathrm{C}$ the reaction is exergonic). ${ }^{7}$

Reaction at $100 \mathrm{C}$ of $t$-butanol on MBH adducts 25 (entry 7, Table 4), which presented a 2-piridinyl moiety, lead to formation of two products, observed by TLC. A more polar product was isolated on 58\% yield and characterized as the pure MAG 11 (entry 7, Table 4). The CGMS analysis of the less polar product indicated that this supposed product by TLC were in fact a more complex mixture of products that were not possible to be isolated. However, in the largest proportion byproduct ( $43 \%$ in this mixture) was proposed to be the unpublished indolizine $\mathbf{2 8}$ (Figure 3). Since this molecule could not be purified by flash chromatography, no NMR data could were obtained and $\mathbf{2 8}$ preparation was based on the CGMS data. This compound showed all the characteristic fragmentations $(\mathrm{m} / \mathrm{z})$ of the indolizine ${ }^{28}$ and also all the expected fragmentations showed in Figure 3, that no doubt characterizes the molecule 28. In fact, is already well established in the literature that indolizines are synthesized at high temperatures..$^{29} \mathrm{We}$ presented in Scheme 4 a short proposal of mechanism reaction for the $\mathbf{2 8}$ formation.

As expected, the MAG 11 could be prepared in good yield without byproducts formations by decreasing the temperature at $60^{\circ} \mathrm{C}$ (entry 8 , Table 4 ). Then, it is clear that in lower temperature the addition of less nucleophilic $t$-butanol solvent on $\mathbf{2 5}$ do not occurs and also the formation of indolizines was not observed.

It is important to detach that both reactions with adducts presenting 3-pyridinyl (26) and 4-pyridinyl (27) moieties give best yields than the reaction with the $\mathbf{2 5}$ adduct (in the same experimental condition, compare the entries 3, 7 and 10, Table 4). This experimental observation also confirms what has been discussed here about 2-N participation.

Finally, we believe that the best conversions to 8,9 and 10 MAGs preparations compared with the conversions in MAGs 11, 12 and $\mathbf{1 3}$ syntheses can be also explained by the possibility of reversibility to the MBH reaction in both protic and nonprotic media as proposed by Cantilo and Kappe. ${ }^{7}$
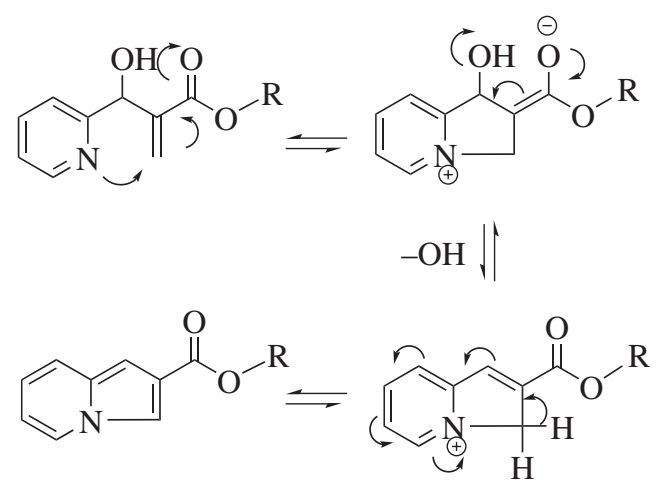

28

Scheme 4. A proposal mechanism of reaction to 28 formation. $\mathrm{R}=$ $\mathrm{CH}_{2} \mathrm{CH}(\mathrm{OH}) \mathrm{CH}_{2} \mathrm{OH}$.

Table 4. Results of the MBHA 8-13 synthesis from step vi, presented in Scheme 3

\begin{tabular}{lccccc}
\hline entry & MBHA & Solvent & $\mathrm{T} /{ }^{\circ} \mathrm{C}$ & time $/$ min & Yields / (\%) \\
\hline 1 & 13 & $\mathrm{CH}_{3} \mathrm{OH}$ & 60 & 60 & $<10$ \\
2 & 13 & $\mathrm{CH}_{3} \mathrm{OH}$ & 100 & 15 & $<10^{*}$ \\
3 & 13 & $t$-butanol & 100 & 15 & 70 \\
4 & 8 & $t$-butanol & 100 & 15 & 90 \\
5 & 9 & $t$-butanol & 100 & 15 & 90 \\
6 & 10 & $t$-butanol & 100 & 15 & 90 \\
7 & 11 & $t$-butanol & 100 & 15 & $58^{* *}$ \\
8 & 11 & $t$-butanol & 60 & 90 & 70 \\
9 & 12 & $t$-butanol & 60 & 60 & 40 \\
10 & 12 & $t$-butanol & 100 & 15 & 70 \\
\hline
\end{tabular}

*Byproducts were observed from chromatography, no identified. **Purified MAG 11 by chromatography.

\section{Conclusions}

In summary we report in this article two efficient, facile and quick synthesis of six new hydrophilic MBHA 
8-13 on high yield (pathway 2, 67-90\% two steps-yields and pathway 1, 54-82\% two steps-yields, Scheme 3 ) from solketal acrylate $\mathbf{2 0}$. We also report a new very efficient and quick synthesis of MAG $\mathbf{2 0}$ from $\mathbf{2 1}$ (100\% yield), using resin and microwave irradiation for $15 \mathrm{~min}$. All steps starting from acrylate $\mathbf{2 0}$ were performed under microwave irradiation methodology. An advantage of pathway 2 is that we can also produce a new more lipophilic MBHA 22-27 in high yields (90-100\% one step from acrylate 20, step v, Scheme 3). The bioactivities evaluations of these new 8-13 hydrophilic MAGs and also the new hydrophobic MBHA 22-27 will continue with this present article.

\section{Experimental}

\section{General}

All commercially available reagents and solvent were obtained from commercial providers and used without further purification. Reactions were monitored by TLC using silica gel 60 UV254 Macherey-Nagel pre-coated silica gel plates; detection was by means of a UV lamp. Flash column chromatography was performed on 300-400 mesh silica gel. Organic layers were dried over anhydrous $\mathrm{MgSO}_{4}$ or $\mathrm{Na}_{2} \mathrm{SO}_{4}$ prior to evaporation on a rotary evaporator. Reactions requiring microwave irradiation were performed in a microwave reactor $\mathrm{CEM}^{\circledR}$ model system Discover benchmate with temperature monitored by built-in infrared sensor. ${ }^{1} \mathrm{H}$ NMR and ${ }^{13} \mathrm{C}$ NMR spectra were recorded using Varian Mercury Spectra AC 20 spectrometer $\left(200 \mathrm{MHz}\right.$ for ${ }^{1} \mathrm{H}, 50 \mathrm{MHz}$ for ${ }^{13} \mathrm{C}$ ) for adducts 22-27 together with the acrylates $\mathbf{2 0}$ and $\mathbf{2 1}$ acrylates and Bruker DPX300 spectrometer (300 MHz for ${ }^{1} \mathrm{H}, 75 \mathrm{MHz}$ for ${ }^{13} \mathrm{C}$ ) for the adducts $\mathbf{8 - 1 3}$. Chemical shifts were reported relative to internal tetramethylsilane $(\delta 0.00$ ppm) for ${ }^{1} \mathrm{H}$, and $\mathrm{CDCl}_{3}(\delta 77.0 \mathrm{ppm})$ for ${ }^{13} \mathrm{C}$. FTIR spectra were recorded on a Shimadzu spectrophotometer model IRPrestige-21 in $\mathrm{KBr}$ pellets. MS data were measured with a Shimadzu GCMS-QP2010 mass spectrometer. High resolution mass spectra were determined using a MicroTOF Ic Bruker Daltonics spectrometer ${ }^{\circledR}$. Solketal were prepared in this work as described in Results and Discussion section and characterized in accordance with the commercial compounds physical data.

\section{(2,2-Dimethyl-1,3-dioxolan-4-yl)methyl acrylate (20 $)^{21}$}

The reaction was performed using solketal $6 \mathrm{~g}$ (0.045 mols) which was left under stirring at $0{ }^{\circ} \mathrm{C}$ with $80 \mathrm{~mL}$ of dichloromethane $\left(\mathrm{CH}_{2} \mathrm{Cl}_{2}\right)$ and $7 \mathrm{~mL}$ of TEA in a closed system. After $5 \mathrm{~min}$, a solution containing $20 \mathrm{~mL}$ of $\mathrm{CH}_{2} \mathrm{Cl}_{2}$ and $4.8 \mathrm{~mL}$ of acryloyl chloride was slowly added. The reaction mixture kept under magnetic stirring for $1 \mathrm{~h}$ at room temperature. Then the isolation was done by adding the reaction mixture a solution of sodium bicarbonate $\mathrm{NaHCO}_{3} 10 \%$ and the product was extracted by the organic phase $\left(\mathrm{CH}_{2} \mathrm{Cl}_{2}\right)$, which, in turn, was dried with sodium sulfate anhydrous $\mathrm{Na}_{2} \mathrm{SO}_{4}$ and concentrated under reduced pressure where it was obtained a $94 \%$ isolated yield. ${ }^{1} \mathrm{H}$ NMR $\left(\mathrm{CDCl}_{3}, 200 \mathrm{MHz}\right): \delta 1.38(\mathrm{~s}, 3 \mathrm{H}), 1.41$ (s, 3H), 3.71-4.41 (m, 5H), 5.84 (dd, $1 \mathrm{H}, J 10.2 / 1.6 \mathrm{~Hz})$, 6.13 (dd, $1 \mathrm{H}, J 17.2 / 10.2 \mathrm{~Hz}), 6.43$ (dd, $1 \mathrm{H}, J 17.2 / 1.6 \mathrm{~Hz}$ ); ${ }^{13} \mathrm{C} \mathrm{NMR}\left(\mathrm{CDCl}_{3}, 50 \mathrm{MHz}\right): \delta 29.3,30.6,68.7,70.2,77.5$, $113.8,131.9,135.4,169.8$.

\section{Synthesis of 2,3-dihydroxypropyl acrylate $(\mathbf{2 1})^{21}$}

It was produced using $186 \mathrm{mg}(1 \mathrm{mmol})$ of the corresponding acrylate $\mathbf{2 0}, 5 \mathrm{~mL}$ of methanol and $100 \mathrm{mg}$ of resin Amberlyst 15 that were placed in a $10 \mathrm{~mL}$ glass microwave tube with magnetic stirrer. The reaction tube was placed inside the cavity of a CEM Discover benchmate and irradiated at $60{ }^{\circ} \mathrm{C}$ for $15 \mathrm{~min}$. After the reaction completes, the reaction mixture brought to room temperature and was directly filtered using methanol and concentrated in a rotary evaporator. ${ }^{1} \mathrm{H}$ NMR $\left(\mathrm{CDCl}_{3}, 200 \mathrm{MHz}\right): \delta 3.39-4.71(\mathrm{~m}, 7 \mathrm{H}), 5.86(\mathrm{dd}, 1 \mathrm{H}$, $J$ 10.4/1.6 Hz), 6.13 (dd, 1H, $J$ 17.2/10.4 Hz), 6.43 (dd, $1 \mathrm{H}, J 17.2 / 1.6 \mathrm{~Hz}) ;{ }^{13} \mathrm{C} \mathrm{NMR}\left(\mathrm{CDCl}_{3}, 50 \mathrm{MHz}\right): \delta 67.2$, $69.2,74.0,131.8,135.8,170.6$.

\section{A typical procedure for synthesis of 22-27 (Scheme 3)}

The corresponding aldehydes $(1,5 \mathrm{mmol}), 186 \mathrm{mg}$ ( $1 \mathrm{mmol}$ ) of acrylate $\mathbf{2 0}$, DABCO (1 equiv.) and $5 \mathrm{~mL}$ of appropriate solvent were placed in a $10 \mathrm{~mL}$ glass microwave tube with magnetic stirrer. The reaction tube was placed inside the cavity of a CEM Discover ${ }^{\circledast}$ benchmate and irradiated at $100^{\circ} \mathrm{C}$ for $10 \mathrm{~min}$. After the reaction completes, the reaction mixture brought to room temperature where the solvent used were extracted from the reaction medium and the product was isolated from the crude reaction by column chromatography through silica gel, using AcOEt:hexane as solvent at a ratio of 3:7 to the adducts $\mathbf{2 2 , 2 3}$ and $\mathbf{2 4}$ and 7:3 to the adducts $\mathbf{2 5 , 2 6}$ and $\mathbf{2 7}$. The reaction products were concentrated under reduced pressure and characterized by NMR, IR and mass spectroscopy.

(2,2-Dimethyl-1,3-dioxolan-4-yl)methyl[2-(hydroxy(2nitrophenyl)methyl)] acrylate (22)

${ }^{1} \mathrm{H}$ NMR $\left(\mathrm{CDCl}_{3}, 200 \mathrm{MHz}\right): \delta 1.31(\mathrm{~s}, 3 \mathrm{H}), 1.38(\mathrm{~s}$, $3 \mathrm{H}), 3.60-4.34(\mathrm{~m}, 6 \mathrm{H}), 5.70(\mathrm{~d}, 1 \mathrm{H}, J 5.8 \mathrm{~Hz}), 6.20(\mathrm{~s}, 1 \mathrm{H})$, $6.38(\mathrm{~s}, 1 \mathrm{H}), 7.45(\mathrm{~m}, 1 \mathrm{H}), 7.63(\mathrm{t}, 1 \mathrm{H}, J 7.8 \mathrm{~Hz}), 7.75(\mathrm{~d}$, $1 \mathrm{H}, J 8.0 \mathrm{~Hz}), 7.94(\mathrm{~d}, 1 \mathrm{H}, J 8.0 \mathrm{~Hz}) ;{ }^{13} \mathrm{C} \mathrm{NMR}\left(\mathrm{CDCl}_{3}\right.$, 
$50 \mathrm{MHz}): \delta 29.1,30.5,69.5,70.0,71.1,77.2,113.8,128.5$, 130.9, 132.6, 132.8, 137.5, 140.3, 144.8, 152.1, 169.4; IR (KBr) $v_{\text {max }} / \mathrm{cm}^{-1}: 3433,2989,2939,2889,1724,1527$, 1350, 1157, 1053; ESI-HRMS (m/z) calc. for $\mathrm{C}_{16} \mathrm{H}_{19} \mathrm{NO}_{7}$ $\left[(\mathrm{M}+\mathrm{H})^{+}\right]$338.1195, found 338.1233.

(2,2-Dimethyl-1,3-dioxolan-4-yl)methyl[2-(hydroxyl(3nitrophenyl)]methyl) acrylate (23)

${ }^{1} \mathrm{H}$ NMR $\left(\mathrm{CDCl}_{3}, 200 \mathrm{MHz}\right): \delta 1.34(\mathrm{~s}, 3 \mathrm{H}), 1.40(\mathrm{~d}$, $3 \mathrm{H}, J 4.0 \mathrm{~Hz}), 3.65-4.37(\mathrm{~m}, 6 \mathrm{H}), 5.67(\mathrm{~d}, 1 \mathrm{H}, J 4.6 \mathrm{~Hz})$, $6.01(\mathrm{~d}, 1 \mathrm{H}, J 5.2 \mathrm{~Hz}), 6.47(\mathrm{~s}, 1 \mathrm{H}), 7.52(\mathrm{t}, 1 \mathrm{H}, J 7.8 \mathrm{~Hz})$, 7.75 (d, 1H, J 7.6 Hz), 8.15 (d, 1H, J $8.0 \mathrm{~Hz}), 8.27$ (s, 1H); ${ }^{13} \mathrm{C} \mathrm{NMR}\left(\mathrm{CDCl}_{3} 50 \mathrm{MHz}\right): \delta 29.1,30.6,69.1,69.9,75.9$, 77.2, 113.8, 125.7, 126.6, 131.4, 133.2, 136.8, 145.1, 147.9, 152.2, 169.4; IR (KBr) $v_{\max } / \mathrm{cm}^{-1}: 3437,2989,2935,2889$, 1716, 1531, 1350, 1157, 1053; ESI-HRMS $(\mathrm{m} / \mathrm{z})$ calc. for $\mathrm{C}_{16} \mathrm{H}_{19} \mathrm{NO}_{7}\left[(\mathrm{M}+\mathrm{H})^{+}\right]$338.1195, found 338.1239.

(2,2-Dimethyl-1,3-dioxolan-4-yl)methyl[2-(hydroxyl(4nitrophenyl)methyl)] acrylate (24)

${ }^{1} \mathrm{H}$ NMR $\left(\mathrm{CDCl}_{3}, 200 \mathrm{MHz}\right): \delta 1.31(\mathrm{~s}, 3 \mathrm{H}), 1.36(\mathrm{~d}$, $3 \mathrm{H}, J 4.0 \mathrm{~Hz}), 3.62-4.33(\mathrm{~m}, 5 \mathrm{H}), 4.44(\mathrm{sl}, 1 \mathrm{H}), 5.64(\mathrm{~d}$, $1 \mathrm{H}, J 4.2 \mathrm{~Hz}), 5.97$ (d, 1H, J 4.8 Hz), $6.41(\mathrm{~s}, 1 \mathrm{H}), 7.55$ $(\mathrm{d}, 2 \mathrm{H}, J 8.4 \mathrm{~Hz}), 8.15(\mathrm{~d}, 2 \mathrm{H}, J 8.6 \mathrm{~Hz}) ;{ }^{13} \mathrm{C} \mathrm{NMR}\left(\mathrm{CDCl}_{3}\right.$ $50 \mathrm{MHz}): \delta 29.1,30.6,70.0,69.9,75.5,77.2,113.8$, 127.4, 131.2, 131.5, 145.3, 151.2, 153.2, 169.4; IR (KBr) $v_{\text {max }} / \mathrm{cm}^{-1}: 3410,3213,2985,2935,2897,1716,1519$, 1350, 1157, 1056; ESI-HRMS ( $m / z)$ calc. for $\mathrm{C}_{16} \mathrm{H}_{19} \mathrm{NO}_{7}$ $\left[(\mathrm{M}+\mathrm{H})^{+}\right]$338.1195, found 338.1229.

(2,2-Dimethyl-1,3-dioxolan-4-yl)methyl[2-(hydroxy (pyridin-2-yl)methyl)] acrylate (25)

${ }^{1} \mathrm{H}$ NMR ( $\left.\mathrm{CDCl}_{3}, 200 \mathrm{MHz}\right): \delta 1.30(\mathrm{~s}, 3 \mathrm{H}), 1.36(\mathrm{~d}$, $3 \mathrm{H}, J 3.8 \mathrm{~Hz}), 3.59-4.28(\mathrm{~m}, 5 \mathrm{H}), 4.98(\mathrm{sl}, 1 \mathrm{H}), 5.59$ (s, $1 \mathrm{H}), 5.97(\mathrm{~s}, 1 \mathrm{H}), 6.38(\mathrm{~s}, 1 \mathrm{H}), 7.18(\mathrm{~m}, 1 \mathrm{H}), 7.40(\mathrm{~d}$, $1 \mathrm{H}, J 8.0 \mathrm{~Hz}), 7.65$ (td, $1 \mathrm{H}, J 7.6 / 1.6 \mathrm{~Hz}), 8.49(\mathrm{dd}, 1 \mathrm{H}$, $J$ 4.8/1.0 Hz); ${ }^{13} \mathrm{C} \mathrm{NMR}\left(\mathrm{CDCl}_{3} 50 \mathrm{MHz}\right): \delta 29.2,30.6$, 68.7, 70.2, 76.0, 77.2, 113.7, 125.2, 126.6, 131.5, 140.8, $145.4,152.1,163.4,169.8 ; \mathrm{IR}(\mathrm{KBr}) v_{\max } / \mathrm{cm}^{-1}: 3421,2985$, 2939, 2889, 1720, 1157, 1053; ESI-HRMS ( $\mathrm{m} / \mathrm{z})$ calc. for $\mathrm{C}_{15} \mathrm{H}_{19} \mathrm{NO}_{5}\left[(\mathrm{M}+\mathrm{H})^{+}\right]$294.1296, found 294.1335.

(2,2-Dimethyl-1,3-dioxolan-4-yl)methyl[2(hydroxyl (pyridin-3-yl)methyl)] acrylate (26)

${ }^{1} \mathrm{H}$ NMR $\left(\mathrm{CDCl}_{3}, 200 \mathrm{MHz}\right): \delta 1.32(\mathrm{~s}, 1 \mathrm{H}), 1.38(\mathrm{~d}$, $1 \mathrm{H}, J 3.2 \mathrm{~Hz}), 3.58-4.33(\mathrm{~m}, 6 \mathrm{H}), 5.59(\mathrm{~s}, 1 \mathrm{H}), 6.02(\mathrm{~d}$, $1 \mathrm{H}, J 3.4 \mathrm{~Hz}), 6.43(\mathrm{~s}, 1 \mathrm{H}), 7.25(\mathrm{dd}, 1 \mathrm{H}, J 8.0 / 5.0 \mathrm{~Hz})$, $7.72(\mathrm{~d}, 1 \mathrm{H}, J 8.0 \mathrm{~Hz}), 8.38(\mathrm{~d}, 1 \mathrm{H}, J 4.6 \mathrm{~Hz}), 8.47(\mathrm{~d}$, $1 \mathrm{H}, J 2.0 \mathrm{~Hz}) ;{ }^{13} \mathrm{C} \mathrm{NMR}\left(\mathrm{CDCl}_{3} 50 \mathrm{MHz}\right): \delta 29.1,30.6$, 69.9, 70.0, 74.3, 77.2, 113.8, 127.4, 130.7, 141.5, 145.4, 152.3, 152.5, 169.4; IR (KBr) $v_{\max } / \mathrm{cm}^{-1}: 3124,2989,2877$,
1716, 1145, 1060; ESI-HRMS (m/z) calc. for $\mathrm{C}_{15} \mathrm{H}_{19} \mathrm{NO}_{5}$ $\left[(\mathrm{M}+\mathrm{H})^{+}\right]$294.1296, found 294.1337.

(2,2-Dimethyl-1,3-dioxolan-4-yl)methyl[2-(hydroxyl (pyridin-4-yl)methyl)] acrylate (27)

${ }^{1} \mathrm{H}$ NMR $\left(\mathrm{CDCl}_{3}, 200 \mathrm{MHz}\right): \delta 1.34(\mathrm{~s}, 3 \mathrm{H}), 1.39(\mathrm{~d}$, $3 \mathrm{H}, J 4.2 \mathrm{~Hz}), 3.63-4.35(\mathrm{~m}, 6 \mathrm{H}), 5.55(\mathrm{~s}, 1 \mathrm{H}), 5.96(\mathrm{~d}$, $1 \mathrm{H}, J 4.6 \mathrm{~Hz}), 6.44(\mathrm{~s}, 1 \mathrm{H}), 7.33$ (d, 2H, $J 6 \mathrm{~Hz}), 8.46$ (d, $2 \mathrm{H}, J 4.8) ;{ }^{13} \mathrm{C} \mathrm{NMR}\left(\mathrm{CDCl}_{3} 50 \mathrm{MHz}\right): \delta 29.1,30.6,69.0$, 69.9, 75.5, 77.2, 113.8, 125.5, 131.6, 145.0, 153.4, 155.1, 169.4; IR (KBr) $v_{\max } / \mathrm{cm}^{-1}: 3140,2989,2877,1716,1141$, 1056; ESI-HRMS $(\mathrm{m} / \mathrm{z})$ calc. for $\mathrm{C}_{15} \mathrm{H}_{19} \mathrm{NO}_{5}\left[(\mathrm{M}+\mathrm{H})^{+}\right]$ 294.1296, found 294,1337.

A typical procedure for synthesis of MAGs 8-13 from step iv (Scheme 3)

The corresponding aldehydes $(1.5 \mathrm{mmol}), 146 \mathrm{mg}$ (1 mmol) of acrylate 21, DABCO (1 equiv.) and $5 \mathrm{~mL}$ of acetonitrile $\left(\mathrm{CH}_{3} \mathrm{CN}\right)$ were placed in a $10 \mathrm{~mL}$ glass microwave tube with magnetic stirrer. The reaction tube was placed inside the cavity of a CEM Discover benchmate and irradiated at $100{ }^{\circ} \mathrm{C}$ for $10 \mathrm{~min}$. After the reaction completes, the reaction mixture brought to room temperature where the $\mathrm{CH}_{3} \mathrm{CN}$ was extracted from the reaction medium and the product was isolated from the crude reaction by column chromatography through silica gel, using AcOEt:hexane as solvent at a ratio of 8:2 to the adducts $\mathbf{8 , 9}$ and $\mathbf{1 0}$ and using $\mathrm{MeOH}$ :AcOEt as solvent at a ratio of 1:9 to the adducts $\mathbf{1 1}, \mathbf{1 2}$ and $\mathbf{1 3}$. The reaction products were concentrated under reduced pressure and characterized by NMR, IR and mass spectroscopy.

A typical procedure for synthesis of MAGs 8-13 from step vi (Scheme 3)

The corresponding MBHA 22-27 (1.0 mmol), $5.0 \mathrm{~mL}$ of $t$-butanol and $100 \mathrm{mg}$ of resin Amberlyst 15 were placed in a $10 \mathrm{~mL}$ glass microwave tube with magnetic stirrer. The reaction tube was placed inside the cavity of a CEM Discover ${ }^{\circledR}$ benchmate and irradiated at $100{ }^{\circ} \mathrm{C}$ for $15 \mathrm{~min}$ (except for the adduct $\mathbf{2 5}$ which was irradiated at $60{ }^{\circ} \mathrm{C}$ for $90 \mathrm{~min}$ to get to 11). After the reaction completes, the reaction mixture brought to room temperature and was directly filtered using methanol as solvent and concentrated under reduced pressure. The reaction products were isolated from the crude reaction by column chromatography through silica gel using AcOEt:hexane as solvent at a ratio of 8:2 to the adducts 8,9 and $\mathbf{1 0}$ and using $\mathrm{MeOH}$ : AcOEt as solvent at a ratio of 1:9 to the adducts $\mathbf{1 1}, \mathbf{1 2}$ and $\mathbf{1 3}$. The reaction products were concentrated under reduced pressure and compared by TLC with those obtained in the step iv. 
The MAGs $\mathbf{8}$-13 spectroscopic data

2,3-Dihydroxypropyl[2-(hydroxyl(2-nitrophenyl)methyl)] acrylate (8)

${ }^{1} \mathrm{H}$ NMR (MeOD, $\left.300 \mathrm{MHz}\right): \delta 3.35$ (s, 3H), 3.46-3.55 (m, 2H), 3.79-3.86 (m, 1H), 4.13-4.23 (m, 2H), 5.72-5.74 $(\mathrm{m}, 1 \mathrm{H}), 6.26(\mathrm{~s}, 1 \mathrm{H}), 6.37(\mathrm{~s}, 1 \mathrm{H}), 7.48-7.54(\mathrm{~m}, 1 \mathrm{H})$, 7.66-7.72 (m, 1H), 7.77 (d, 1H, J 7.8 Hz), 7.94 (d, 1H, $J 8.1 \mathrm{~Hz}) ;{ }^{13} \mathrm{C}$ NMR $(\mathrm{MeOH}, 75 \mathrm{MHz}): \delta 64.2,67.0,67.6$, 71.1, 124.5, 126.4, 129.3, 129.8, 134.3, 138.4, 144.2, 167.1; IR (KBr) $v_{\max } / \mathrm{cm}^{-1}: 3383,1712,1527,1350,1265$, 1157, 1120, 1045; ESI-HRMS (m/z) calc. for $\mathrm{C}_{13} \mathrm{H}_{15} \mathrm{NO}_{7}$ $\left[(\mathrm{M}+\mathrm{Na})^{+}\right]$320.0746, found 320.0748.

\section{2,3-Dihydroxypropyl[2-(hydroxyl(3-nitrophenyl)methyl)]} acrylate (9)

${ }^{1} \mathrm{H}$ NMR (MeOD, $\left.300 \mathrm{MHz}\right): \delta 3.35$ (s, 2H), 3.49 (d, 2H, J 5.4 Hz), 3.75-3.83 (m, 1H), 4.07 (ddd, 1H, $J$ 11.4/6.0/4.2 Hz), 4.17 (ddd, 1H, J 11.4/4.5/3.0 Hz), $5.70(\mathrm{~s}, 1 \mathrm{H}), 6.13(\mathrm{dd}, 1 \mathrm{H}, J 2.1 / 1.5 \mathrm{~Hz}), 6.46(\mathrm{dd}, 1 \mathrm{H}$, $J$ 2.4/1.2 Hz), $7.56(\mathrm{t}, 1 \mathrm{H}, J 8.1 \mathrm{~Hz}), 7.77-7.81(\mathrm{~m}, 1 \mathrm{H})$, 8.13 (ddd, $1 \mathrm{H}, J$ 8.1/2.1/0.9 Hz), 8.26 (t, 1H, J $1.8 \mathrm{~Hz}$ ); ${ }^{13} \mathrm{C} \mathrm{NMR}(\mathrm{MeOH}, 75 \mathrm{MHz}): \delta 64.1,67.0,71.1,72.2,123.0$, 123.5, 126.5, 130.6, 134.6, 144.3, 146.4, 149.7, 167.0; IR $(\mathrm{KBr}) \mathrm{V}_{\max } / \mathrm{cm}^{-1}: 3375,1708,1527,1350,1273,1157,1095$, 1049; ESI-HRMS $(\mathrm{m} / \mathrm{z})$ calc. for $\mathrm{C}_{13} \mathrm{H}_{15} \mathrm{NO}_{7}\left[(\mathrm{M}+\mathrm{Na})^{+}\right]$ 320.0746 , found 320.0749 .

\section{2,3-Dihydroxypropyl[2-(hydroxyl(4-nitrophenyl)methyl)] acrylate (10)}

${ }^{1} \mathrm{H}$ NMR (MeOD, $\left.300 \mathrm{MHz}\right): \delta 3.35$ (s, 2H), 3.47-3.51 (m, 3H), 3.75-3.82 (m, 1H), 4.04-4.21 (m, 2H), $5.69(\mathrm{~s}, 1 \mathrm{H})$, $6.10(\mathrm{dd}, 1 \mathrm{H}, J 2.1 / 1.5 \mathrm{~Hz}), 6.44(\mathrm{dd}, 1 \mathrm{H}, J 2.1 / 0.9 \mathrm{~Hz})$, $7.63(\mathrm{~d}, 2 \mathrm{H}, J 9.0 \mathrm{~Hz}), 8.19(\mathrm{~d}, 2 \mathrm{H}, J 9.0 \mathrm{~Hz}) ;{ }^{13} \mathrm{C} \mathrm{NMR}$ $(\mathrm{MeOH}, 75 \mathrm{MHz}): \delta 64.1,67.0,71.1,72.3,124.5,126.6$, $129.3,138.4,144.2,148.9,167.0 ; \mathrm{IR}(\mathrm{KBr}) \mathrm{v}_{\max } / \mathrm{cm}^{-1}: 3375$, 1708, 1519, 1350, 1269, 1157, 1111, 1049; ESI-HRMS $(\mathrm{m} / \mathrm{z})$ calc. for $\mathrm{C}_{13} \mathrm{H}_{15} \mathrm{NO}_{7}\left[(\mathrm{M}+\mathrm{Na})^{+}\right] 320.0746$, found 320.0749 .

2,3-Dihydroxypropyl[2-(hydroxy(pyridin-2-yl)methyl)] acrylate (11)

${ }^{1} \mathrm{H}$ NMR (MeOD, $\left.300 \mathrm{MHz}\right): \delta 3.349$ (s, 2H), 3.470$3.670(\mathrm{~m}, 3 \mathrm{H}), 3.750-3.825(\mathrm{~m}, 1 \mathrm{H}), 4.08(\mathrm{ddd}, 1 \mathrm{H}$, $J 11.4 / 9.0 / 6.0 \mathrm{~Hz}$ ), 4,17 (ddd, 1H, J 11.4/7.5/4.5 Hz), 5.66 (s, 1H), $5.98(\mathrm{~d}, 1 \mathrm{H}, J 0.6 \mathrm{~Hz}), 6.43(\mathrm{~d}, 1 \mathrm{H}, J 0.9 \mathrm{~Hz}), 7.31$ (ddd, 1H, J 7.5/5.1/1.2 Hz), 7.56 (d, 1H, J 8.1 Hz), 7.82 (td, 1H, J 7.8/1.8 Hz), 8.46 (ddd, 1H, J 5.1/1.8/0.9 Hz); ${ }^{13} \mathrm{C}$ NMR $(\mathrm{MeOH}, 75 \mathrm{MHz}): \delta 64.1,67.0,71.1,73.9$, 123.2, 124.2, 127.1, 138.8, 143.8, 149.47, 162.5, 167.3; IR $(\mathrm{KBr}) v_{\max } / \mathrm{cm}^{-1}: 3383,1712,1269,1161,1111,1049$;
ESI-HRMS $(m / z)$ calc. for $\mathrm{C}_{12} \mathrm{H}_{15} \mathrm{NO}_{5}\left[(\mathrm{M}+\mathrm{H})^{+}\right]$254.0983, found 254.1021.

\section{2,3-Dihydroxypropyl[2-(hydroxyl(pyridin-3-yl)methyl)]} acrylate (12)

${ }^{1} \mathrm{H}$ NMR (MeOD, $\left.300 \mathrm{MHz}\right): \delta 3.35$ (s, 2H), 3.47$3.67(\mathrm{~m}, 3 \mathrm{H}), 3.75-3.83(\mathrm{~m}, 1 \mathrm{H}), 4.07$ (ddd, $1 \mathrm{H}$, $J 11.4 / 6.0 / 4.2 \mathrm{~Hz}$ ), 4.17 (ddd, $1 \mathrm{H}, J 11.4 / 4.5 / 2.4 \mathrm{~Hz}$ ), 5.64 $(\mathrm{s}, 1 \mathrm{H}), 6.15(\mathrm{~s}, 1 \mathrm{H}), 6.46(\mathrm{~d}, 1 \mathrm{H}, J 1.2 \mathrm{~Hz}), 7.40$ (ddd, 1H, $J 7.8 / 4.8 / 0.6 \mathrm{~Hz}$ ), 7.84 (dt, 1H, J 8.1/1.8 Hz), 8.43 (dd, 1H, $J$ 4.8/1.5 Hz), 8.56 (d, 1H, J 1.8 Hz); ${ }^{13} \mathrm{C} \mathrm{NMR}(\mathrm{MeOH}$, $75 \mathrm{MHz}): \delta 64.1,67.0,70.9,71.1,125.1,126.2,137.0$, 140.3, 144.1, 149.2, 149.4, 167.0; IR (KBr) $v_{\max } / \mathrm{cm}^{-1}: 3348$, 1716, 1265, 1157, 1118, 1029; ESI-HRMS ( $\mathrm{m} / \mathrm{z})$ calc. for $\mathrm{C}_{12} \mathrm{H}_{15} \mathrm{NO}_{5}\left[(\mathrm{M}+\mathrm{H})^{+}\right]$254.0983, found 254.1023.

2,3-Dihydroxypropyl[2-(hydroxyl(pyridin-4-yl)methyl)] acrylate (13)

${ }^{1} \mathrm{H}$ NMR (MeOD, $\left.300 \mathrm{MHz}\right): \delta 3.35$ (s, 3H), 3.49-3.60 (m, 2H), 3.77-3.83 (m, 1H), 4.06-4.21 (m, 2H), $5.61(\mathrm{~s}, 1 \mathrm{H})$, 6.08 (dd, 1H. J 2.5/1.0 Hz), 6.45 (dd, 1H, J 2.0/1.0 Hz), 7.47 (d, 2H, J 6.5 Hz), 8.47 (dd, 2H, J 4.5/1.5 Hz); ${ }^{13} \mathrm{C}$ NMR $(\mathrm{MeOH}, 75 \mathrm{MHz}): \delta$ 64.1, 64.6, 71.1, 71.8, 123.7, 127.0, $143.9,150.0,167.0$; IR (KBr) $v_{\max } / \mathrm{cm}^{-1}: 3363,1716,1269$, 1161, 1115, 1053; ESI-HRMS $(\mathrm{m} / \mathrm{z})$ calc. for $\mathrm{C}_{12} \mathrm{H}_{15} \mathrm{NO}_{5}$ $\left[(\mathrm{M}+\mathrm{H})^{+}\right]$254.0983, found 254.1027.

\section{Supplementary Information}

Supplementary data are available free of charge at http://jbcs.sbq.org.br as a PDF file.

\section{Acknowledgments}

This work has been supported by CNPq, CAPES and FAPESQ-PB.

\section{References}

1. Morita, K.; Suzuki, Z.; Hirose, H.; Bull. Chem. Soc. Jpn. 1968, 41, 2815; Baylis, A. B.; Hillman, M. E. D.; German Pat. 2155113, 1972 (CA 77: 34174q).

2. For reviews, see: Basavaiah, D.; Reddy, B. S.; Badsara, S. S.; Chem. Rev. 2010, 110, 5447; Basavaiah, D.; Rao, K. V.; Reddy, R. J.; Chem. Soc. Rev. 2007, 36, 1581; Masson, G.; Housseman, C.; Zhu, J.; Angew. Chem., Int. Ed. 2007, 46, 4614; Basavaiah, D.; Rao, J. A.; Satyanarayana, T.; Chem. Rev. 2003, 103, 811.; Langer, P.; Angew. Chem., Int. Ed. 2000, 39, 3049; Coelho, F. A. S.; Almeida, W. P.; Quim. Nova 2000, 23, 98; Basavaiah, D.; Rao, P. D.; Hyma, R. S.; Tetrahedron 1996, 52, 8001; Drewes, S. E.; Roos, G. H. P.; Tetrahedron 1988, 44, 4653. 
3. Hill, J. S.; Isaacs, N. S.; J. Phys. Org. Chem. 1990, 3, 285; Hill, J. S.; Isaacs, N. S.; J. Chem. Res. 1988, 330; Hill, J. S.; Isaacs, N. S.; Tetrahedron Lett. 1996, 27, 5007.

4. Price, K. E.; Broadwater, S. J.; Jung, H. M.; McQuade, D. T.; Org. Lett. 2005, 7, 147; Price, K. E.; Broadwater, S. J.; Walker, B. J.; McQuade, D. T.; J. Org. Chem. 2005, 70, 3980.

5. Aggarwal, V. K.; Fulford, S. Y.; Lloyd-Jones, G. C.; Angew. Chem., Int. Ed. 2005, 44, 1706.

6. Amarante, G. W.; Milagre, H. M. S.; Vaz, B. G.; Ferreira, B. R. V.; Eberlin, M. N.; Coelho, F.; J. Org. Chem. 2009, 74, 3031.

7. Cantillo, D.; Kappe, C. O.; J. Org. Chem. 2010, 75, 8615.

8. Miranda, L. S. M.; Marinho, B. G. S.; Leitão, Matheus, G. E.; Fernandes, M. P. D.; Vasconcellos, M. L. A. A.; Bioorg. Med. Chem. Lett. 2004, 14, 1573; Miranda, L. S. M.; Meireles, B.A.; Costa, J. S.; Pereira, V. L. P.; Vasconcellos, M. L. A. A.; Synlett 2005, 869; Alencar, K. G.; Dumas, F.; Costa, P. R. R.; Vasconcellos, M. L. A. A.; Tetrahedron: Asymmetry 1997, 8, 579; Filho, H. C. A.; Filho, U. F. L.; Pinheiro, S. Vasconcellos, M. L. A. A.; Costa, P. R. R.; Tetrahedron: Asymmetry 1994, 5, 1219; Coelho, A. L.; Vasconcellos, M. L. A. A.; Simas, A. B. C.; Rabi, J. A.; Costa, P. R. R.; Synthesis 1992, 914.

9. de Souza, R. O. M. A.; Pereira, V. L. P.; Esteves, P. M. Vasconcellos, M. L. A. A.; Tetrahedron Lett. 2008, 49, 5902; de Souza, R. O. M. A.; Souza, A. L. F.; Fernandez, T. L.; Silva, A. C.; Pereira, V. L. P.; Esteves, P. M.; Vasconcellos, M. L. A. A.; Antunes, O. A. C.; Lett. Org. Chem. 2008, 5, 379; de Souza, R. O. M. A.; Vasconcellos, M. L. A. A.; Catal. Commun. 2004, 5, 21; de Souza, R. O. M. A.; Meireles, B. A.; Aguiar, C. S.; Vasconcellos, M. L. A. A.; Synthesis 2004, 1595; de Souza, R. O. M. A.; Vasconcellos, M. L. A. A.; Synth. Commun. 2003, 33, 1393.

10. Vasconcellos, M. L. A. A.; Silva, T. M. S.; Camara, C. A.; Martins, R. M.; Lacerda, K. M.; Lopes, H. M.; Pereira, V. L. P.; de Souza, R. O. M. A.; Crespo, L. T. C.; Pest Manage. Sci. 2006, 62, 288.

11. de Souza, R. O. M. A.; Pereira, V. L. P.; Muzitano, M. F.; RossiBergmann, B.; Filho, E. B. A.; Vasconcellos, M. L. A. A.; Eur. J. Med. Chem. 2007, 42, 99.

12. Barbosa, T. C.; Junior, C. G. L.; Silva, F. P. L. Lopes, H. M. Figueiredo, L. R. F.; Souza, S. C. O.; Batista, G. N.; Silva,T. G.; Silva, T. M.; Oliveira, M. R.; Vasconcellos, M. L. A. A.; Eur. J. Med. Chem. 2009, 44, 1726.

13. Sandes, J. M.; Borges, A. R.; Junior, C. G. L.; Silva, F. P. L. Carvalho, G. A. U.; Rocha, G. B.; Vasconcellos, M. L. A. A.; Figueiredo, R. C. B. Q.; Bioorg. Chem. 2010, 38, 190.

14. Junior, C. G. L.; de Assis, P. A. C.; Silva, F. P. L.; Sousa, S. C. O.; Andrade, N. G.; Barbosa, T. P.; Nerís, P. L. N.; Segundo, L. V. G.; Anjos, I. C.; Carvalho, G. A. U.; Rocha, G. B.; Oliveira, M. R.; Vasconcellos, M. L. A. A.; Bioorg. Chem. 2010, 38, 279.
15. Choe1, J.; Guerra, D.; Michels, P. A. M.; Hol, W. G. J.; J. Mol. Biol. 2003, 329, 335; Yu, C. C.; Lee, Y-S.; Cheon, B-S.; Lee, S. H.; Bull. Korean Chem. Soc. 2003, 24, 1229.

16. Almela, M. J.; Torres, P. A.; Lozano, S.; Herreros, E.; Toxicol. in vitro 2009, 23, 1528; Charris, J. E.; Lobo, G. M.; Camacho, J.; Ferrer, R.; Barazarte, A.; Domínguez, J. N.; Gamboa, N.; Rodrigues, J. R.; Angel, J. E.; Lett. Drug Des. Discovery 2007, 4, 49; Sanders, J. M.; Gomez, A. O.; Mao, J.; Meints, G. A.; Van Brussel, E. M.; Burzynska, A.; Kafarski, P.; GonzalezPacanowska, D.; Oldfield, E.; J. Med. Chem. 2003, 46, 5171; Liu, M.; Wilairat, P.; Croft, S. L.; Lay-Choo A.; Go Mei-Lin.; Bioorg. Med. Chem. 2003, 11, 2729; Loyevsky, M.; Cabantchik, Z. I.; Mol. Pharmacol. 1994, 45, 446.

17. Kappe, C. O.; Dallinger, D.; Mol. Divers. 2009, 13, 71; Larhed, M.; Olofsson, K.; Topics in Current Chemistry: Microwave Methods in Organic Synthesis; Springer: Berlin, 2006.

18. de Souza, R. O. M. A.; Miranda, L. S. M.; Mini-Rev. Org. Chem. 2010, 7, 212; Bose, A. K.; Manhas, M. S.; Ganguly, S. N.; Sharma, A. H.; Banik, B. K.; Synthesis 2002, 1578; Nuchter, M.; Ondruschka, B.; Bonrath, W.; Gum, A.; Green Chem. 2004, 6, 128.

19. Yu, C. C.; Lee, Y-S.; Cheon, B. S.; Lee, S. H.; Bull. Korean Chem. Soc. 2003, 24, 1229.

20. Obtained data from Sciencefinder ${ }^{\circledR}$, accessed in January 2011.

21. Zhifeng, F.; Tao, W.; Shi, Y.; J. Polym. Sci., Part A: Polym. Chem. 2008, 46, 362.

22. He, Y.; Johansson, M.; Sterner, O.; Synth. Commun. 2004, 34 , 4153.

23. Ichihara, I.; Ubakaba, M.; Sakamura, S.; Tetrahedron Lett. 1977, 18,3473 .

24. Kim, K. S.; Song, Y. H.; Lee, B. H.; Hahn, C. S.; J. Org. Chem. 1986, 51, 404.

25. Fleet, G. W. J.; Smith, P. W.; Tetrahedron Lett. 1985, 26, 1469.

26. Li, T-S.; Li, S-H.; Synth. Commun. 1997, 27, 2299.

27. Batovska, D. I.; Kishmoto, T.; Bankova, V. S.; Kamenarska, Z. G.; Ukubata, M.; Molecules 2005, 10, 552.

28. For indolizine mass spectra, see: http://webbook .nist.gov/cgi/ cbook.cgi? Spec $=$ C274408\&Idex $=0$ \& Type=Mass \&Large $=$ on, accessed in January 2011, or visit: http://webbook.nist.gov/ chemistry/[search=indolizine+mass spectra].

29. Basavaiah, D.; Devendar, B.; Lenin, D. V.; Satyanarayana, T.; Synlett 2009, 411; Jiang, M.; He, Q.; Yang, C.; Xie, Y.; Heterocycles 2008, 75, 2659; Basavaiah, D.; Rao, A.; J. Chem. Commun. 2003, 604; Basavaiah, D.; Rao, A. J.; Tetrahedron Lett. 2003, 44, 4365; Bode, M. L.; Kaye, P. T. J.; Chem. Soc., Perkin Trans. 1 1993, 180.

Submitted: January 31, 2011 Published online: June 2, 2011 


\section{Microwave-Promoted Morita-Baylis-Hillman Reactions: Efficient Synthesis of New Monoacylglycerols (MAGs) as Potential Anti-Parasitic Compounds}

Suervy C. O. Sousa, Claudio G. L. Junior, Fábio P. L. Silva, Natália G. Andrade, Ticiano P. Barbosa and Mário L. A. A. Vasconcellos*

Departamento de Química, Universidade Federal da Paraíba, Campus I, 58059-900 João Pessoa-PB, Brazil

(2,2-Dimethyl-1,3-dioxolan-4-yl)methyl acrylate (20)<smiles>C=CC(=O)OCC1COC(C)(C)O1</smiles>

${ }^{1} \mathrm{H}$ NMR $\left(\mathrm{CDCl}_{3}, 200 \mathrm{MHz}\right): \delta 1.38(\mathrm{~s}, 3 \mathrm{H}), 1.41(\mathrm{~s}, 3 \mathrm{H}), 3.71-4.41(\mathrm{~m}, 5 \mathrm{H}), 5.84(\mathrm{dd}, 1 \mathrm{H}, J 10.2 / 1.6 \mathrm{~Hz}), 6.13(\mathrm{dd}$, $1 \mathrm{H}, J 17.2 / 10.2 \mathrm{~Hz}), 6.43(\mathrm{dd}, 1 \mathrm{H}, J 17.2 / 1.6 \mathrm{~Hz}) ;{ }^{13} \mathrm{C} \mathrm{NMR}\left(\mathrm{CDCl}_{3} 50 \mathrm{MHz}\right): \delta 29.3,30.6,68.7,70.2,77.5,113.8,131.9$, $135.4,169.8$.

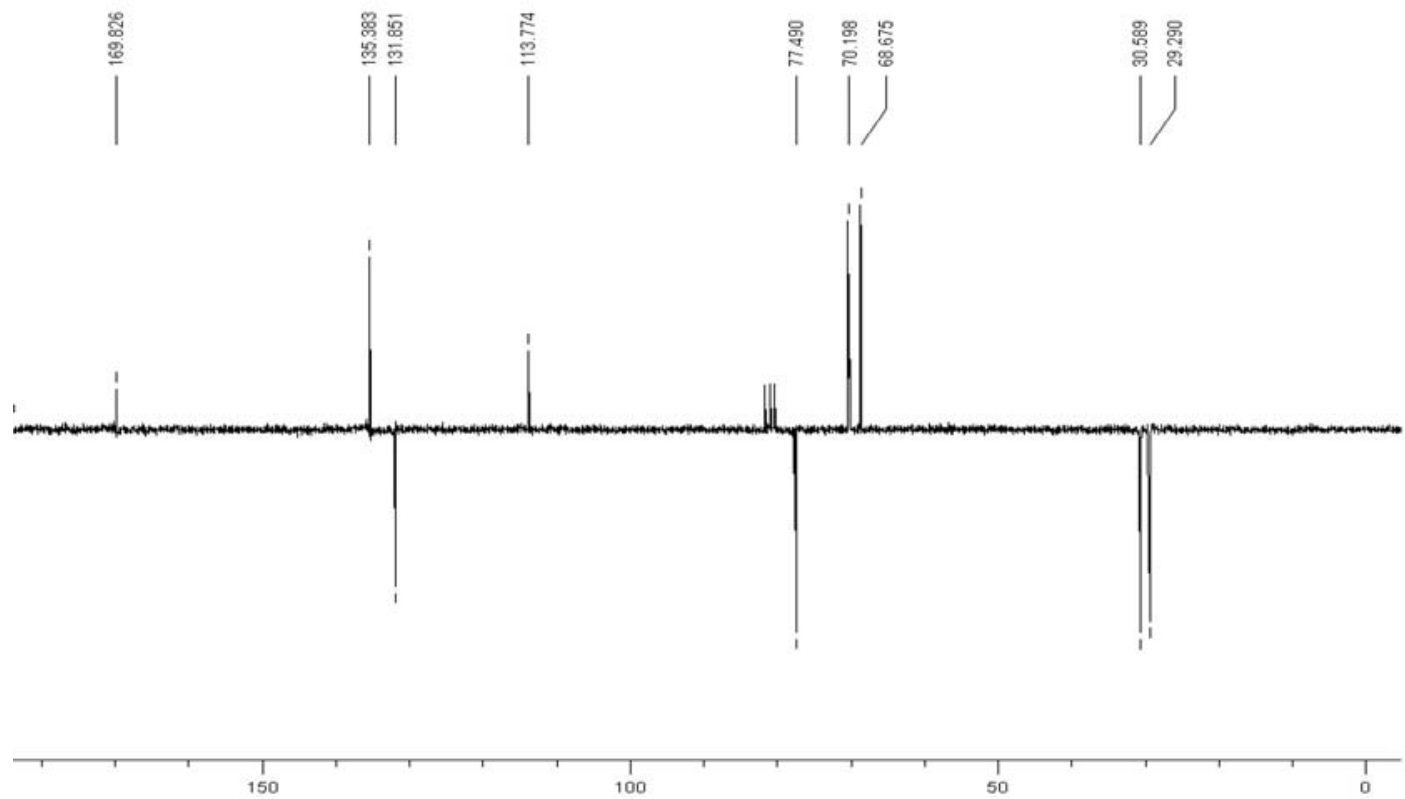

Figure S1. ${ }^{13} \mathrm{C}$ NMR spectrum of compound $\mathbf{2 0}$. 

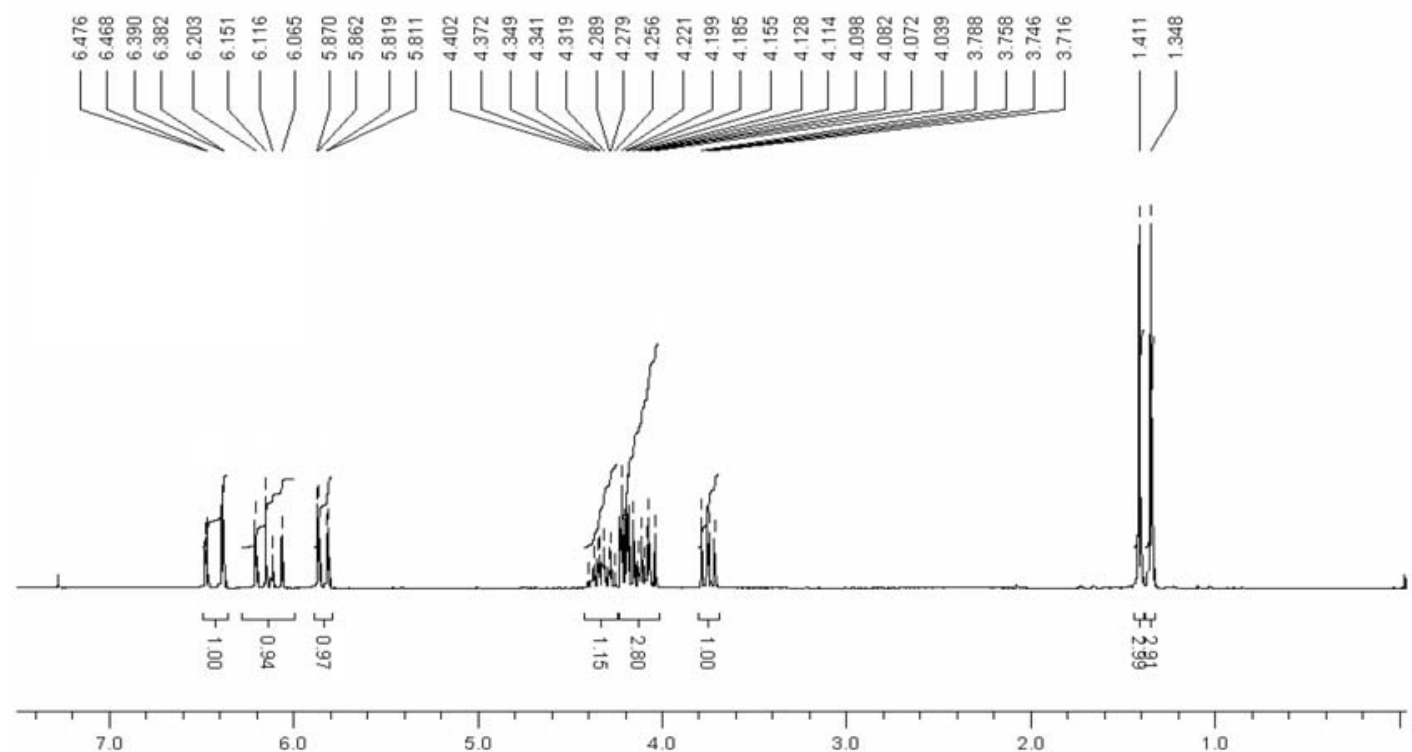

Figure S2. ${ }^{1} \mathrm{H}$ NMR spectrum of compound 20.
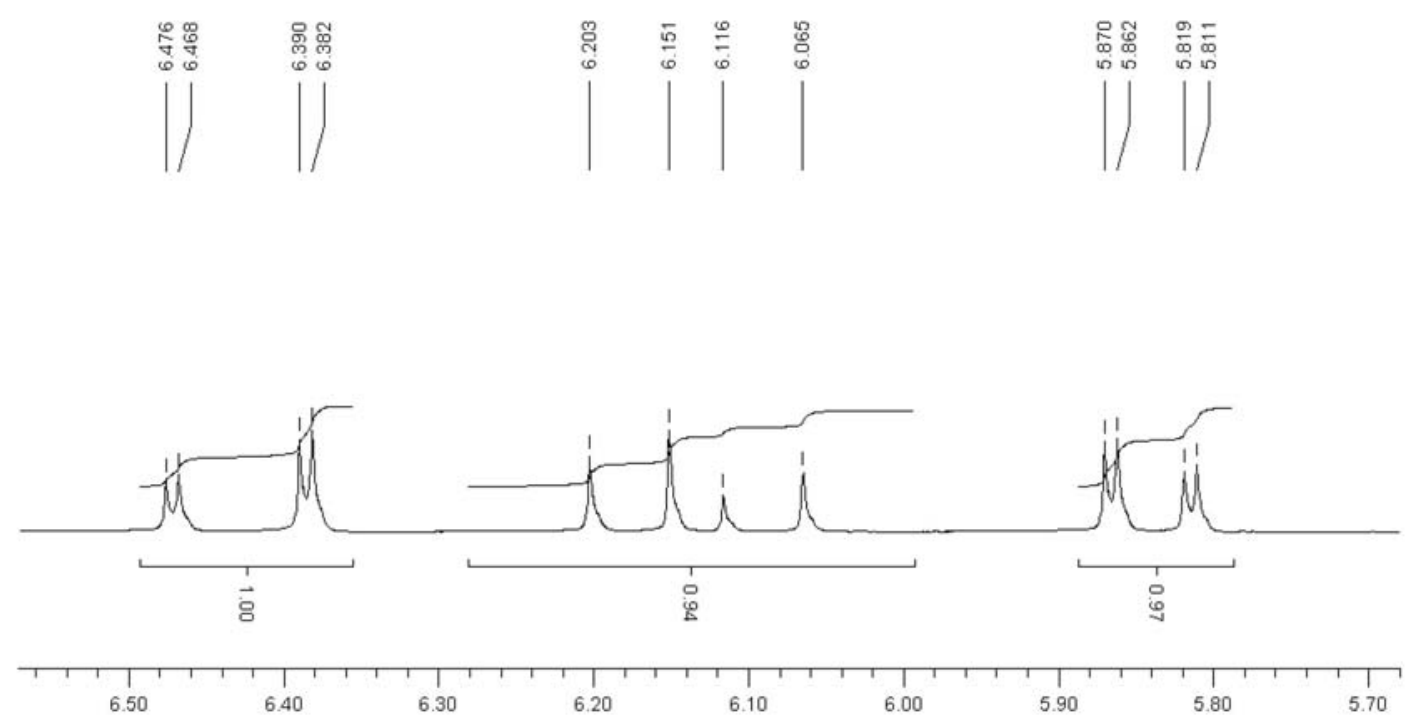

Figure S3. ${ }^{1} \mathrm{H}$ NMR spectrum of compound 20. 
2,3-Dihydroxypropyl acrylate (21)<smiles>C=CC(=O)OCC(O)CO</smiles>

${ }^{1} \mathrm{H} \mathrm{NMR}\left(\mathrm{CDCl}_{3}, 200 \mathrm{MHz}\right): \delta 3.39-4.71(\mathrm{~m}, 7 \mathrm{H}), 5.86(\mathrm{dd}, 1 \mathrm{H}, J 10.4 / 1.6 \mathrm{~Hz}), 6.13(\mathrm{dd}, 1 \mathrm{H}, J 17.2 / 10.4 \mathrm{~Hz}), 6.43(\mathrm{dd}$, $1 \mathrm{H}, J 17.2 / 1.6 \mathrm{~Hz}) ;{ }^{13} \mathrm{C} \mathrm{NMR}\left(\mathrm{CDCl}_{3} 50 \mathrm{MHz}\right): \delta 67.2,69.2,74.0,131.8,135.8,170.6$.

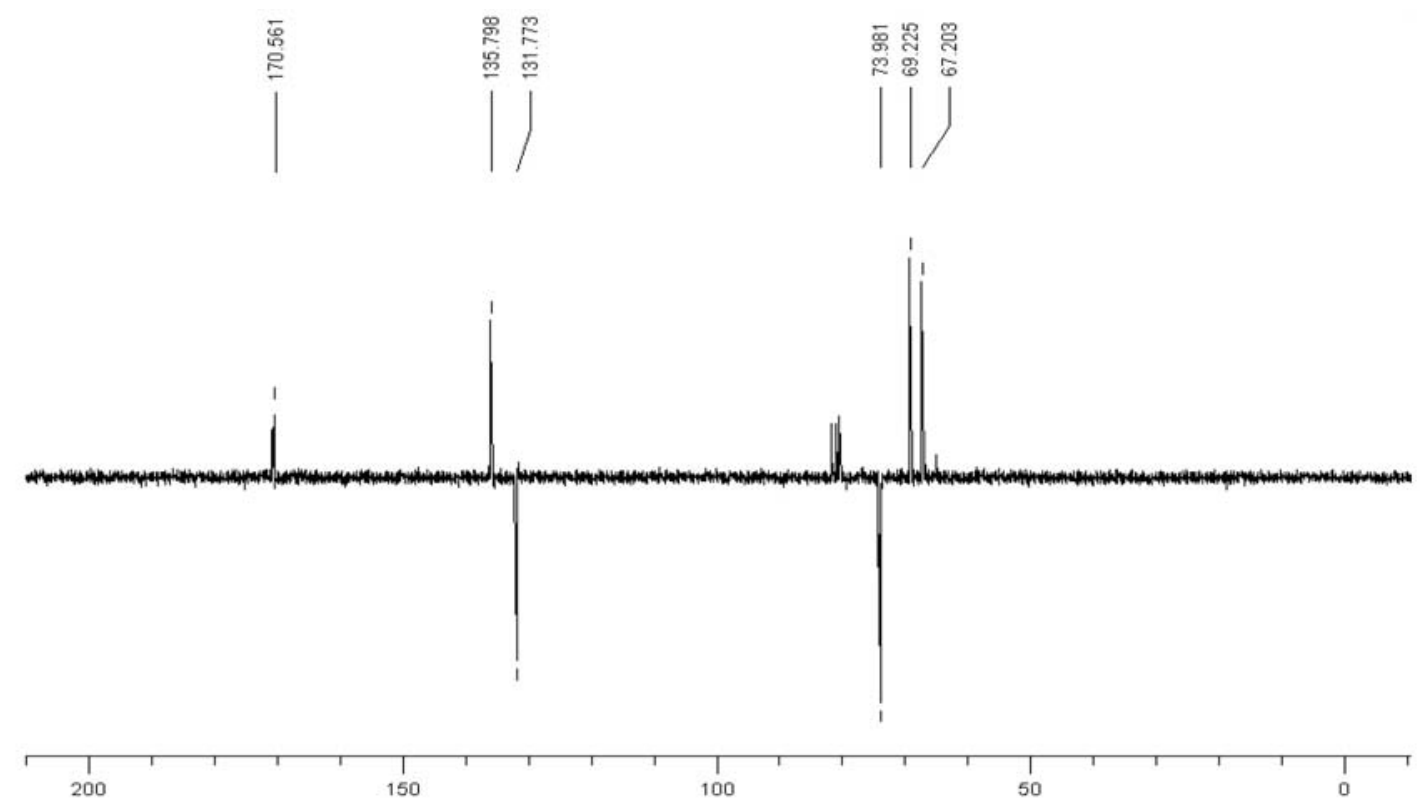

Figure S4. ${ }^{13} \mathrm{C}$ NMR spectrum of compound 21.

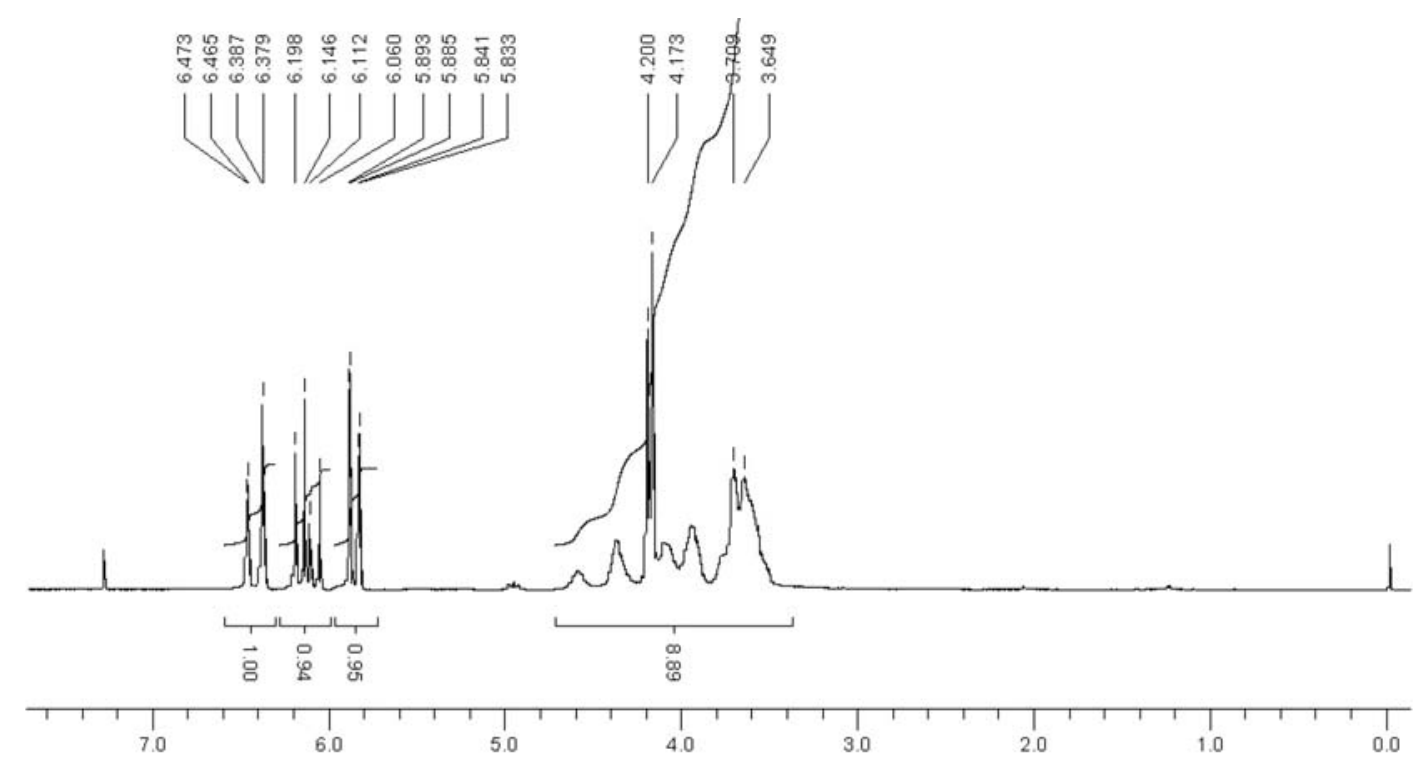

Figure S5. ${ }^{1} \mathrm{H}$ NMR spectrum of compound 21. 

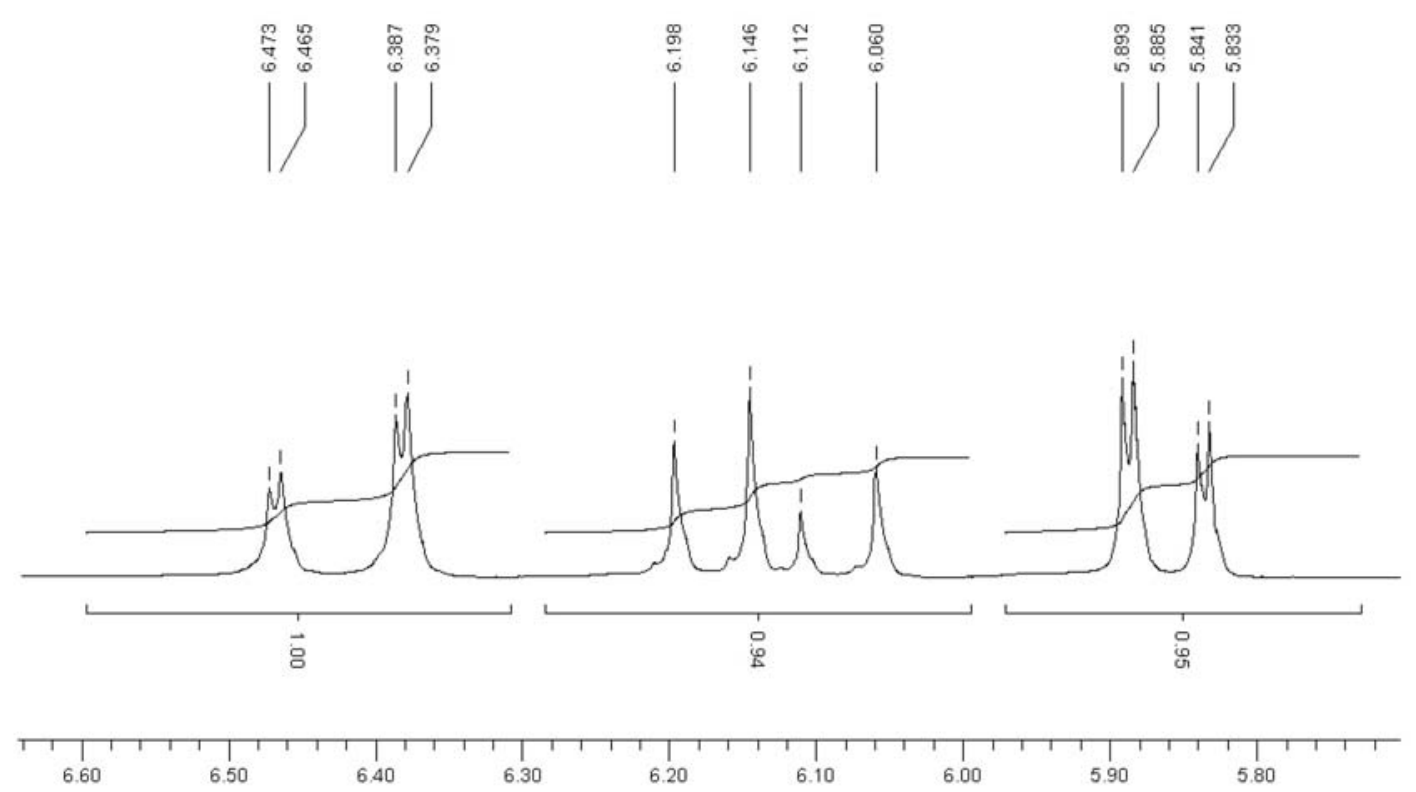

Figure S6. ${ }^{1} \mathrm{H}$ NMR spectrum of compound 21.

(2,2-Dimethyl-1,3-dioxolan-4-yl)methyl[2-(hydroxy(2-nitrophenyl)methyl)] acrylate (22)

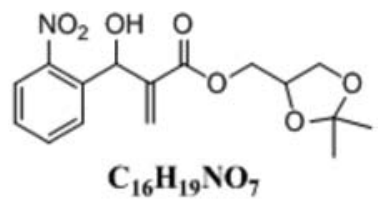

${ }^{1} \mathrm{H}$ NMR $\left(\mathrm{CDCl}_{3}, 200 \mathrm{MHz}\right): \delta 1.31(\mathrm{~s}, 3 \mathrm{H}), 1.38(\mathrm{~s}, 3 \mathrm{H}), 3.60-4.34(\mathrm{~m}, 6 \mathrm{H}), 5.70(\mathrm{~d}, 1 \mathrm{H}, J 5.8 \mathrm{~Hz}), 6.20(\mathrm{~s}, 1 \mathrm{H}), 6.38(\mathrm{~s}$, $1 \mathrm{H}), 7.45(\mathrm{~m}, 1 \mathrm{H}), 7.63(\mathrm{t}, 1 \mathrm{H}, J 7.8 \mathrm{~Hz}), 7.75(\mathrm{~d}, 1 \mathrm{H}, J 8.0 \mathrm{~Hz}), 7.94(\mathrm{~d}, 1 \mathrm{H}, J 8.0 \mathrm{~Hz}) ;{ }^{13} \mathrm{C} \mathrm{NMR}\left(\mathrm{CDCl}_{3} 50 \mathrm{MHz}\right): \delta 29.1$, $30.5,69.5,70.0,71.1,77.2,113.8,128.5,130.9,132.6,132.8,137.5,140.3,144.8,152.1,169.4 ; \mathrm{IR}(\mathrm{KBr}) \mathrm{v}_{\max } / \mathrm{cm}^{-1}: 3433$, 2989, 2939, 2889, 1724, 1527, 1350, 1157, 1053; ESI-HRMS $(\mathrm{m} / \mathrm{z})$ calc. for $\mathrm{C}_{16} \mathrm{H}_{19} \mathrm{NO}_{7}\left[(\mathrm{M}+\mathrm{H})^{+}\right] 338.1195$, found 338.1233.

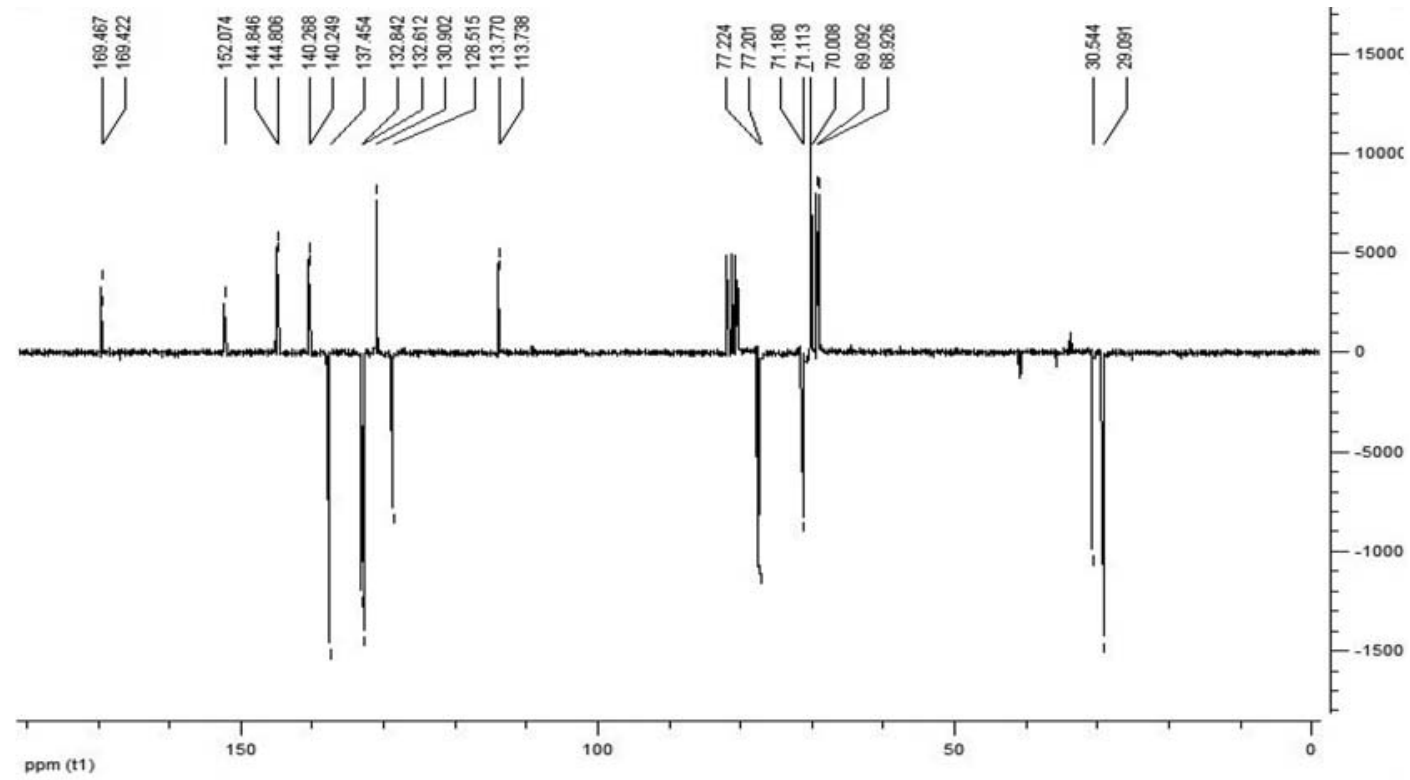

Figure S7. ${ }^{13} \mathrm{C}$ NMR spectrum of compound 22. 


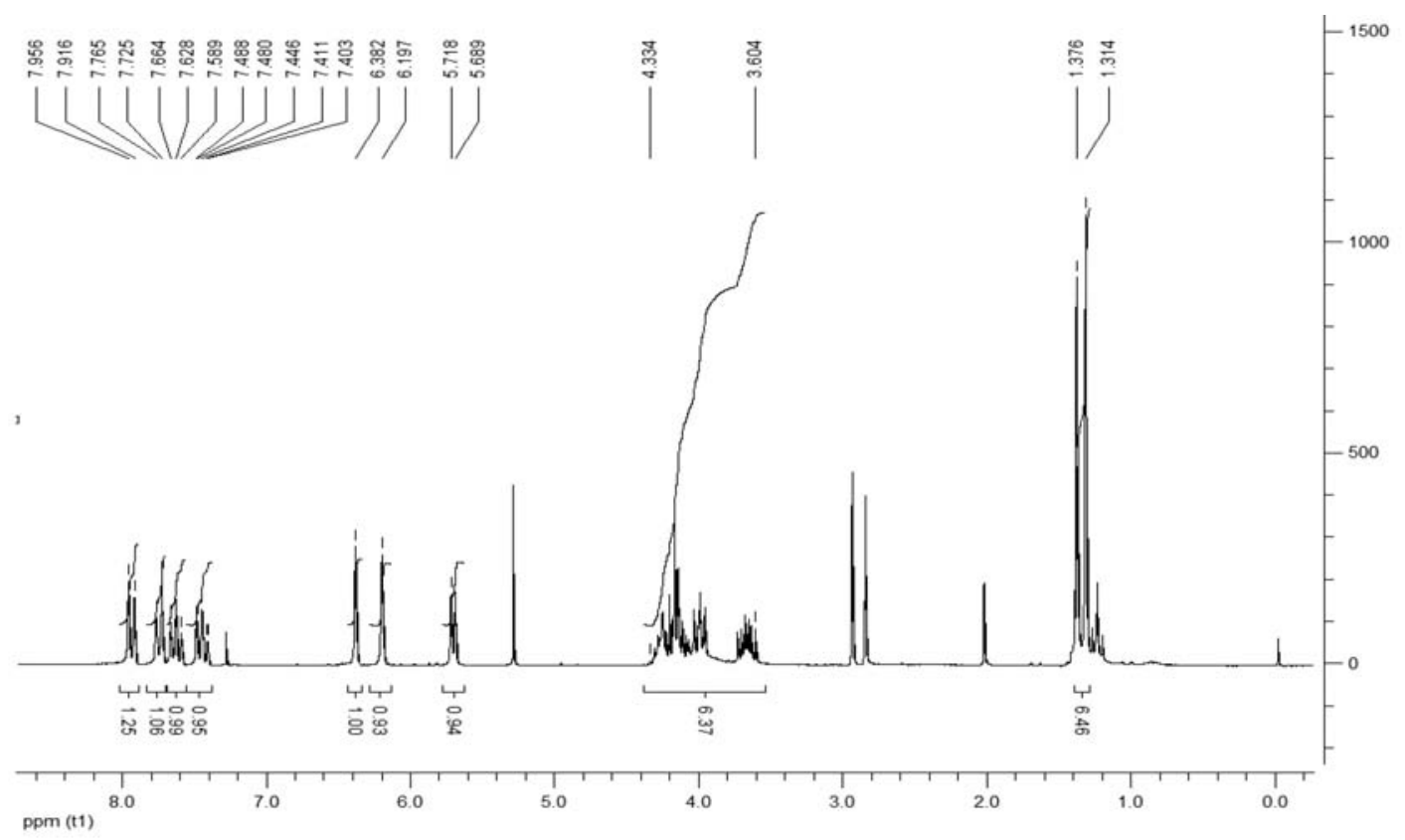

Figure S8. ${ }^{1} \mathrm{H}$ NMR spectrum of compound 22.

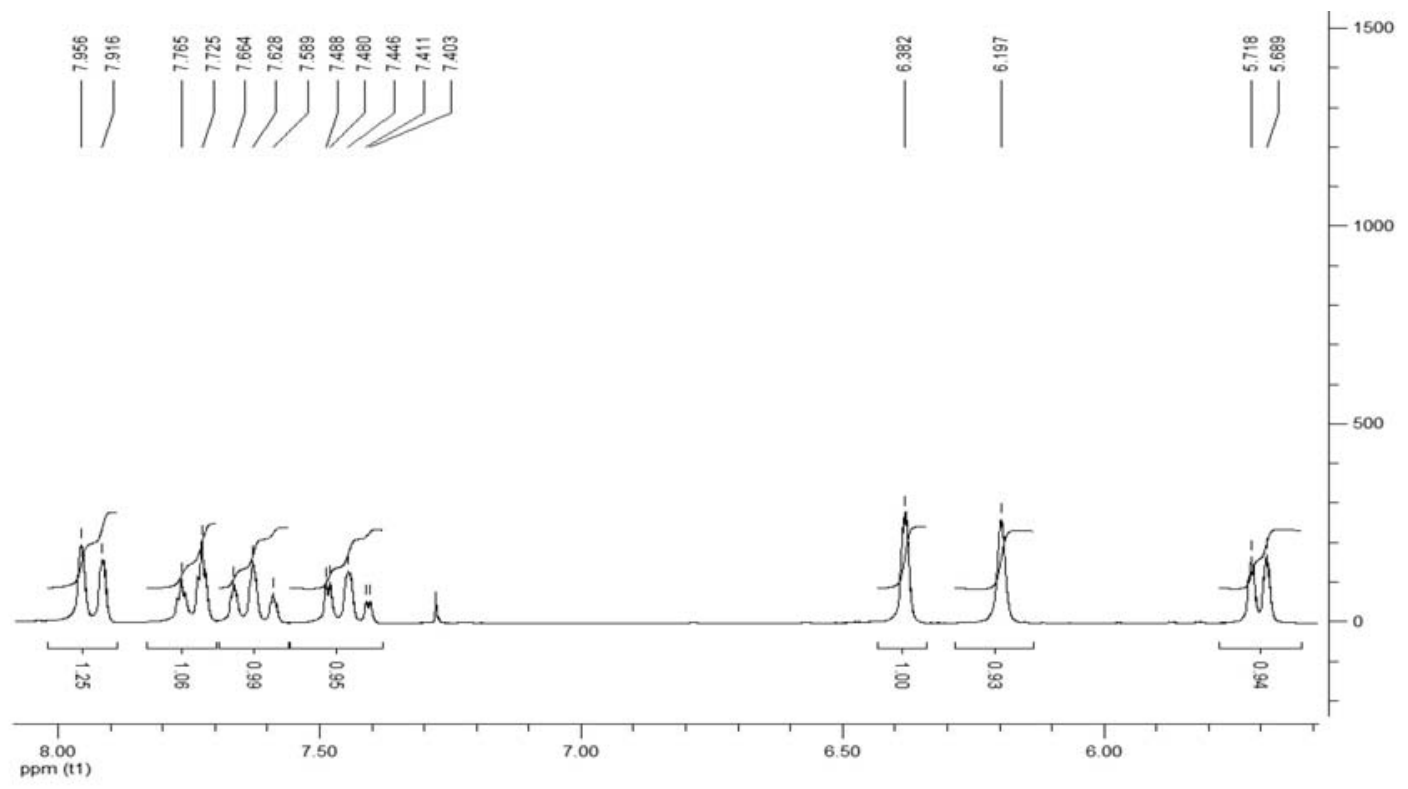

Figure S9. ${ }^{1} \mathrm{H}$ NMR spectrum of compound 22. 


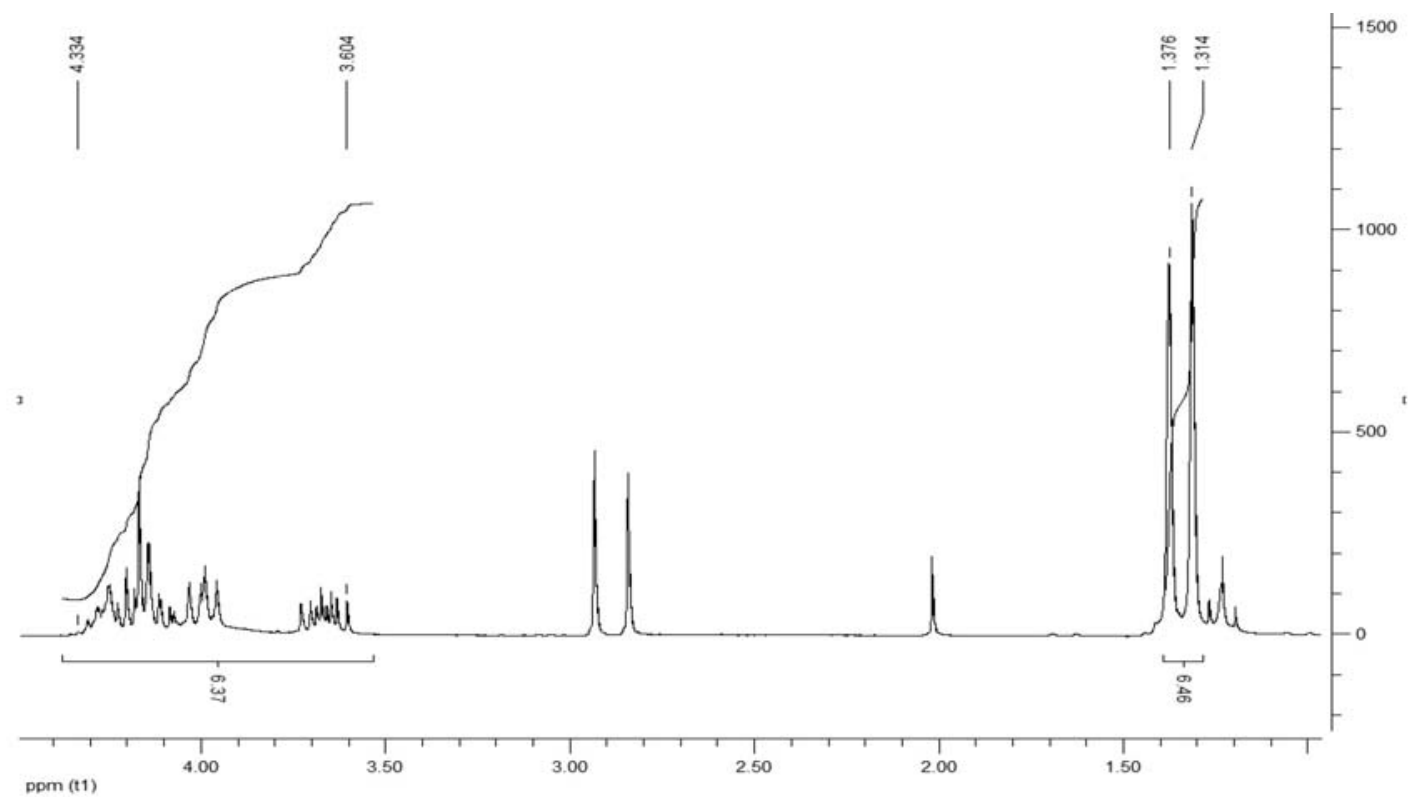

Figure S10. ${ }^{1} \mathrm{H}$ NMR spectrum of compound 22.

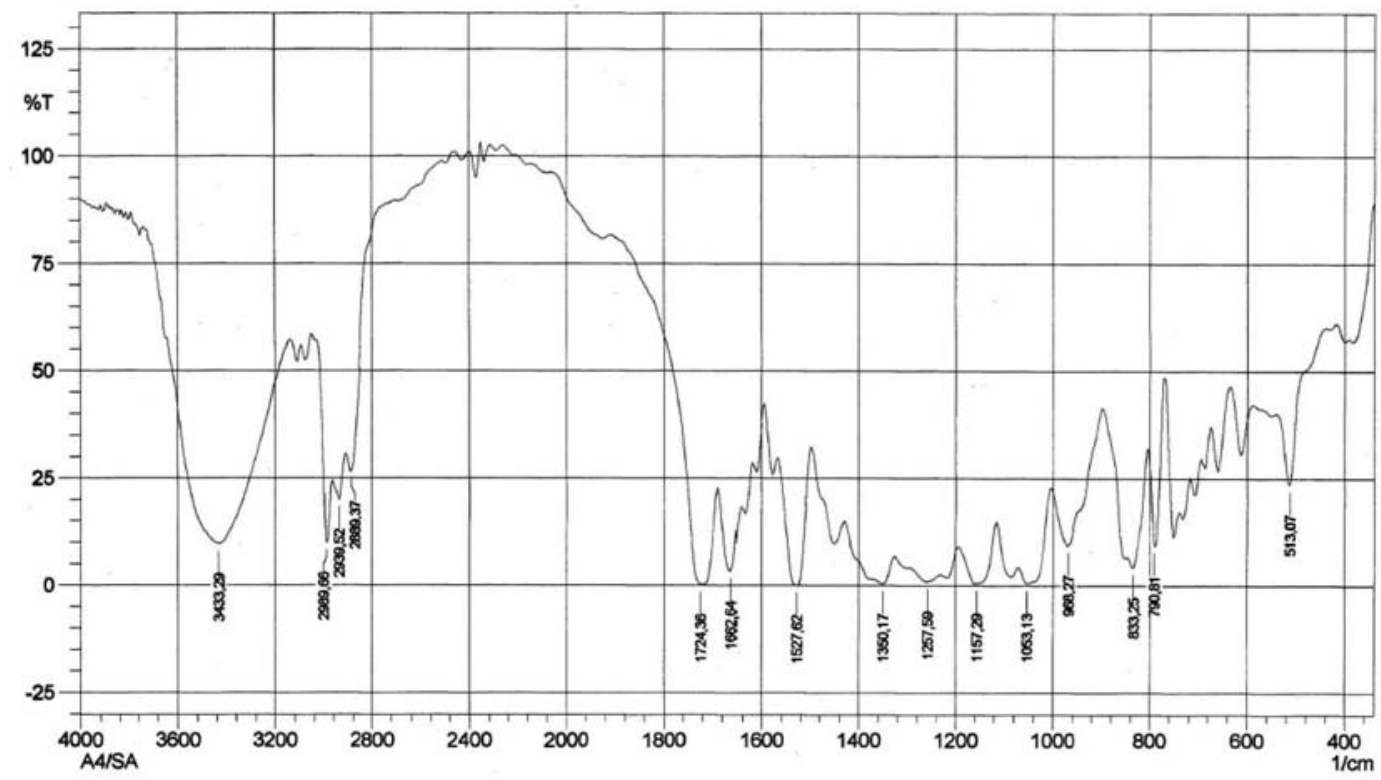

Figure S11. IR spectrum of compound 22. 


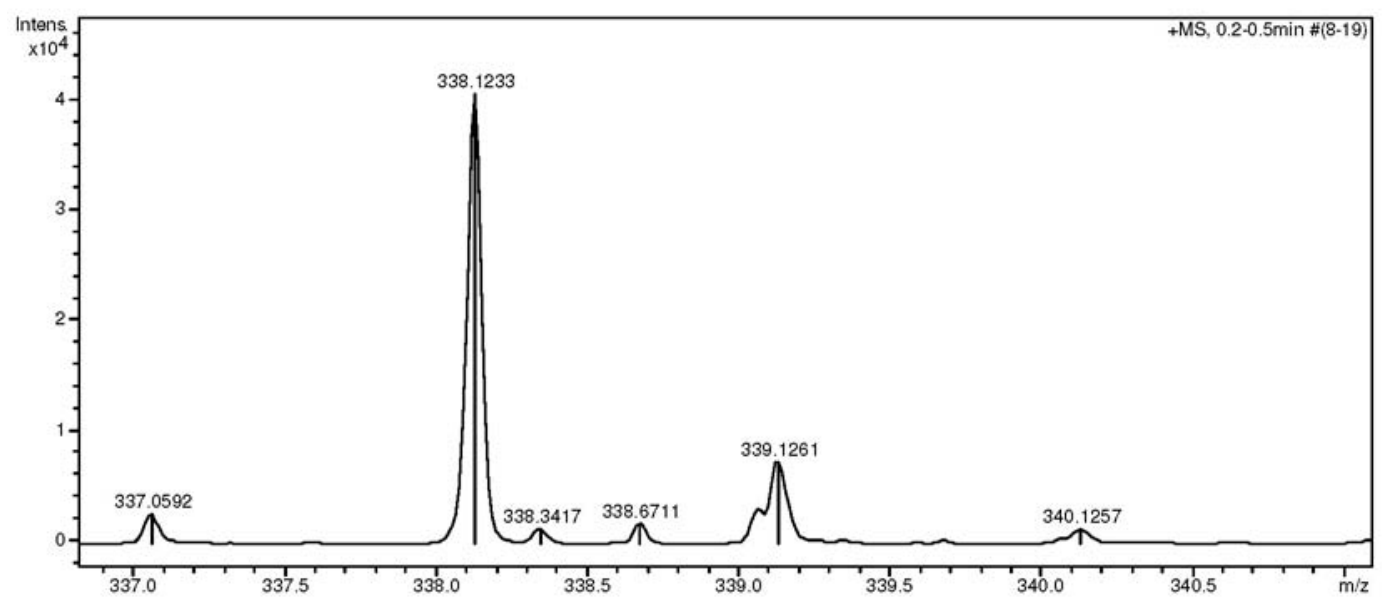

Figure S12. ESI-HRMS spectrum of compound 22.

(2,2-Dimethyl-1,3-dioxolan-4-yl)methyl[2-(hydroxyl(3-nitrophenyl)]methyl) acrylate (23)<smiles>C=C(C(=O)OCC1COC(C)(C)O1)C(O)c1cccc([N+](=O)[O-])c1</smiles>

${ }^{1} \mathrm{H}$ NMR $\left(\mathrm{CDCl}_{3}, 200 \mathrm{MHz}\right): \delta 1.34(\mathrm{~s}, 3 \mathrm{H}), 1.40(\mathrm{~d}, 3 \mathrm{H}, J 4.0 \mathrm{~Hz}), 3.65-4.37(\mathrm{~m}, 6 \mathrm{H}), 5.67(\mathrm{~d}, 1 \mathrm{H}, J 4.6 \mathrm{~Hz}), 6.01(\mathrm{~d}$, $1 \mathrm{H}, J 5.2 \mathrm{~Hz}), 6.47(\mathrm{~s}, 1 \mathrm{H}), 7.52(\mathrm{t}, 1 \mathrm{H}, J 7.8 \mathrm{~Hz}), 7.75(\mathrm{~d}, 1 \mathrm{H}, J 7.6 \mathrm{~Hz}), 8.15(\mathrm{~d}, 1 \mathrm{H}, J 8.0 \mathrm{~Hz}), 8.27(\mathrm{~s}, 1 \mathrm{H}) ;{ }^{13} \mathrm{C} \mathrm{NMR}$ $\left(\mathrm{CDCl}_{3} 50 \mathrm{MHz}\right): \delta 29.1,30.6,69.1,69.9,75.9,77.2,113.8,125.7,126.6,131.4,133.2,136.8,145.1,147.9,152.2,169.4$; IR (KBr) $v_{\max } / \mathrm{cm}^{-1}: 3437,2989,2935,2889,1716,1531,1350,1157,1053$; ESI-HRMS $(\mathrm{m} / z)$ calc. for $\mathrm{C}_{16} \mathrm{H}_{19} \mathrm{NO}_{7}\left[(\mathrm{M}+\mathrm{H})^{+}\right]$ 338.1195 , found 338.1239 .
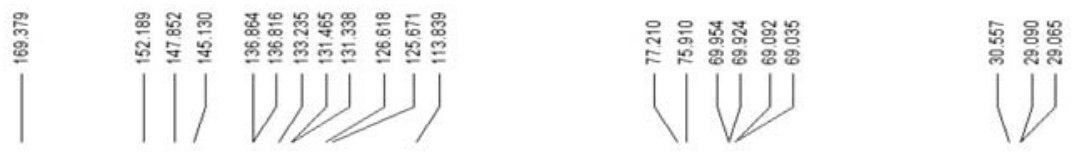

4000
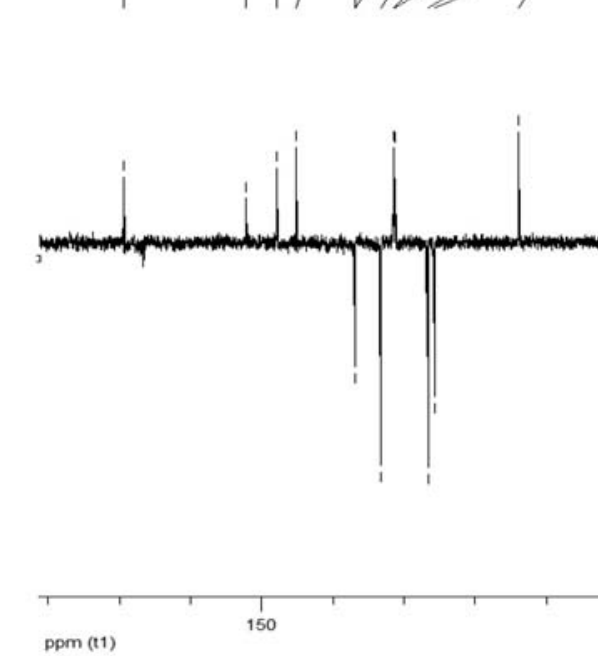

Figure S13. ${ }^{13} \mathrm{C}$ NMR spectrum of compound 23. 


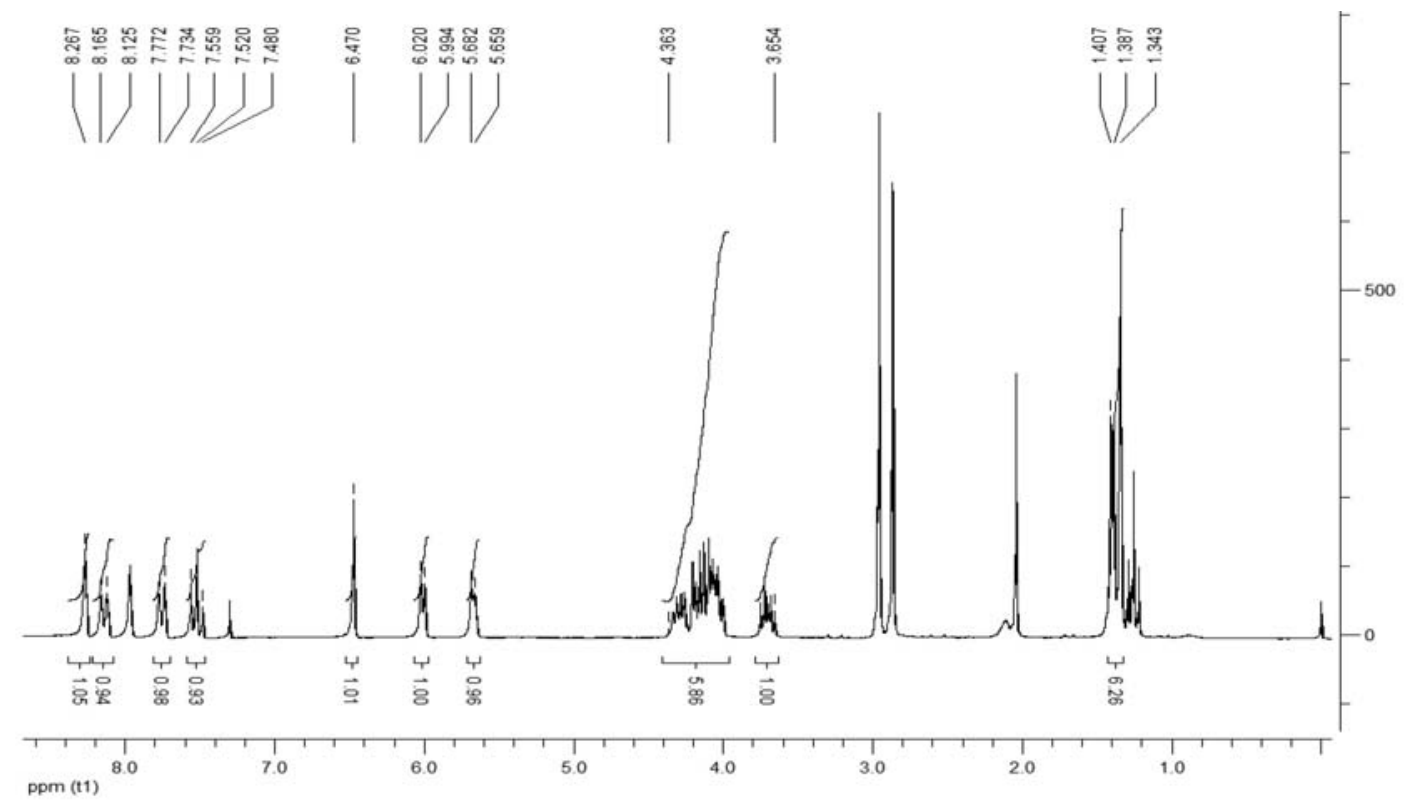

Figure S14. ${ }^{1} \mathrm{H}$ NMR spectrum of compound 23.

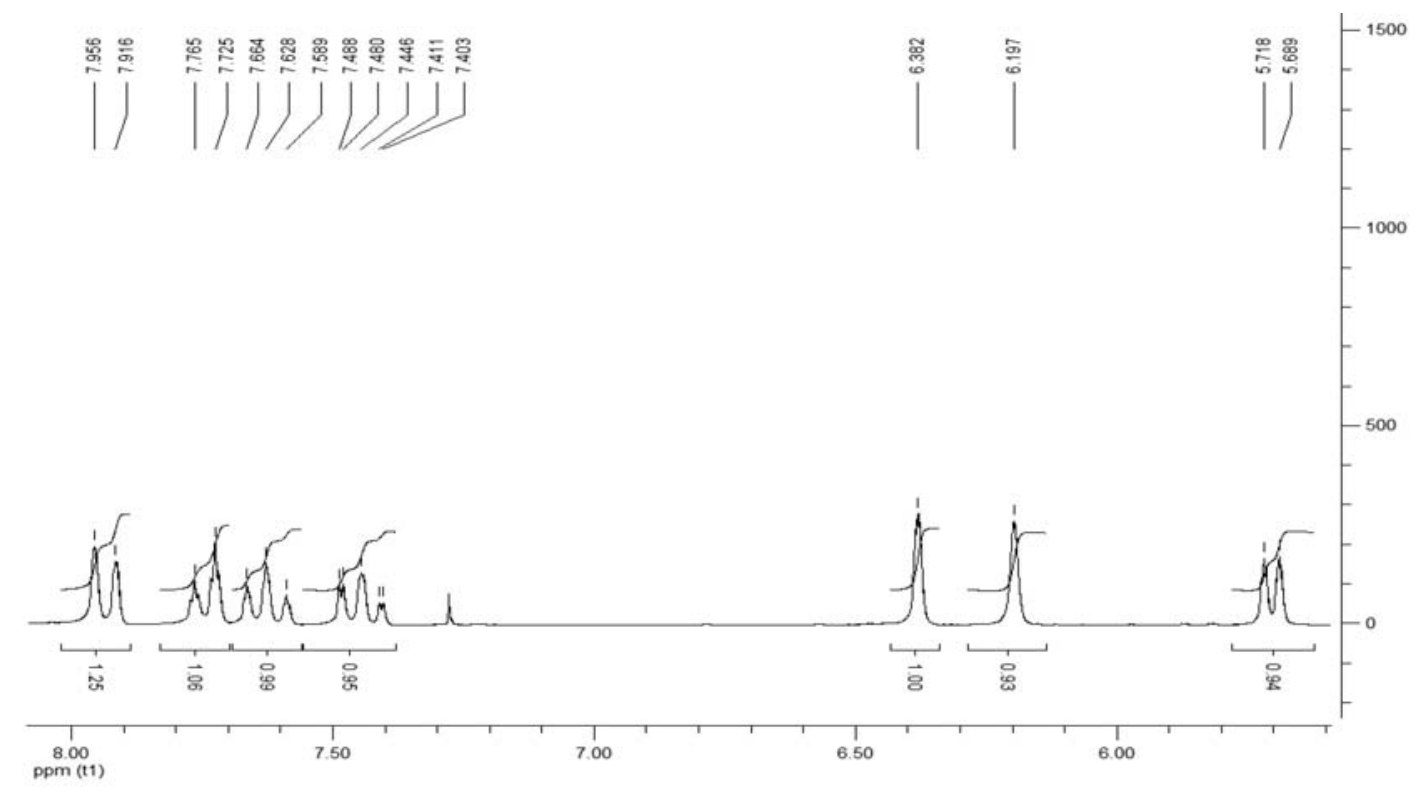

Figure S15. ${ }^{1} \mathrm{H}$ NMR spectrum of compound 23. 


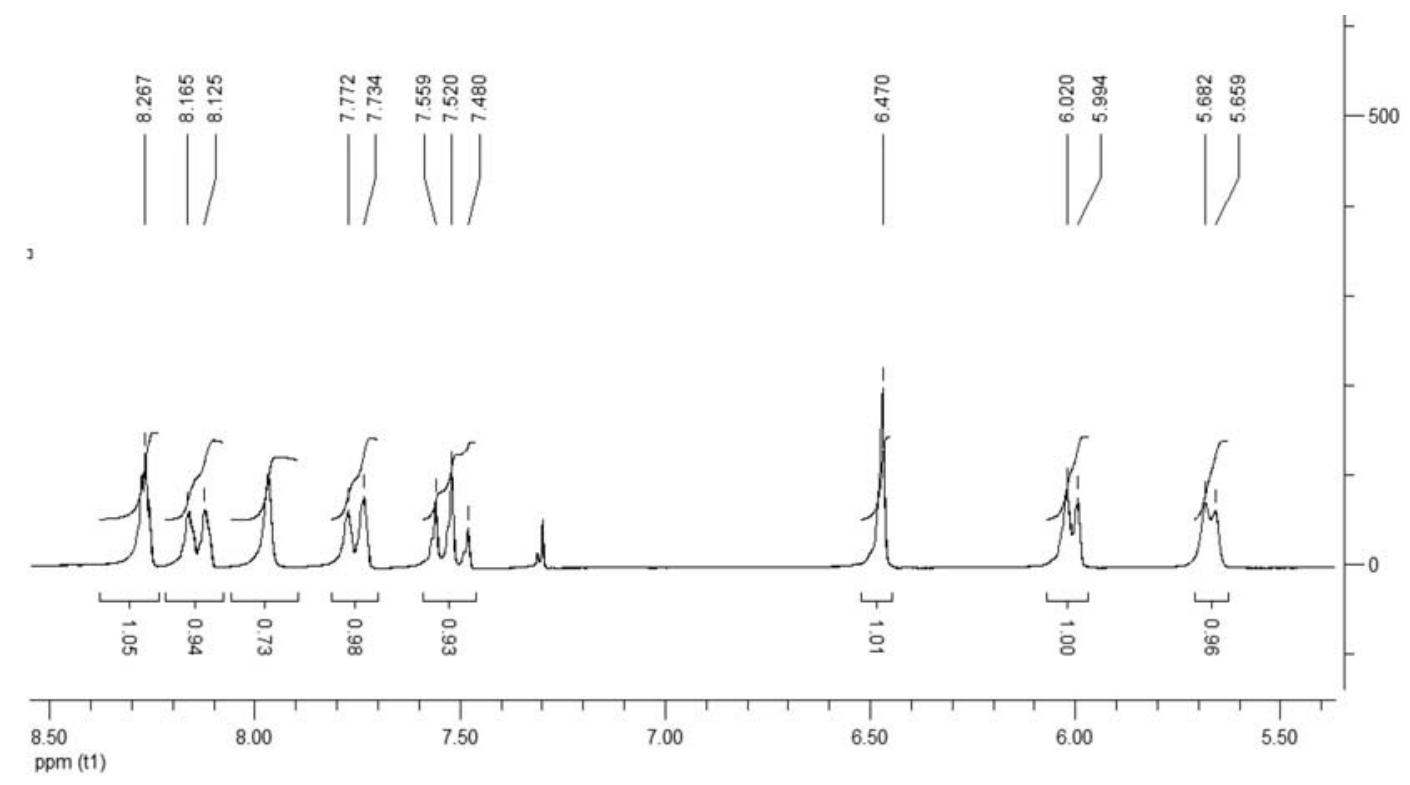

Figure S16. ${ }^{1} \mathrm{H}$ NMR spectrum of compound 23.

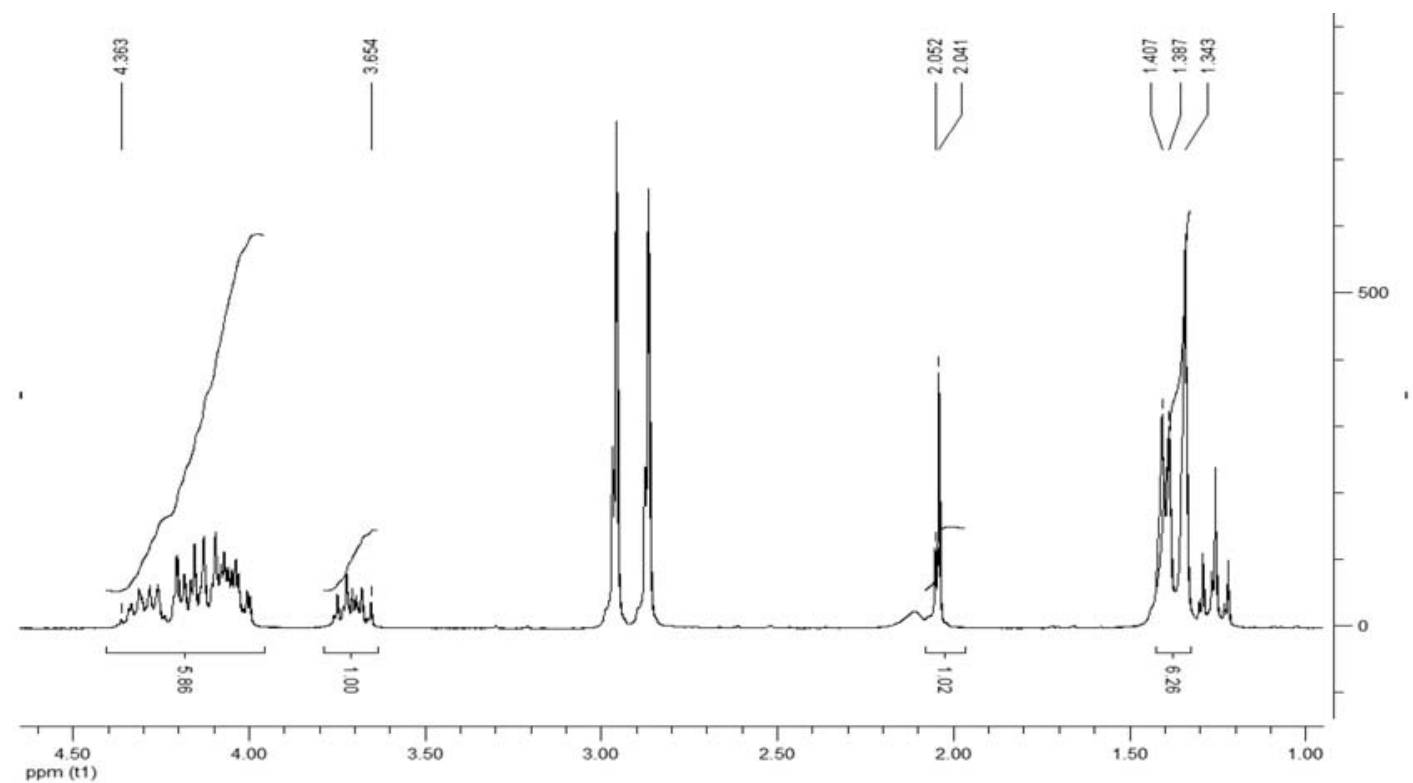

Figure S17. ${ }^{1} \mathrm{H}$ NMR spectrum of compound $\mathbf{2 3}$. 


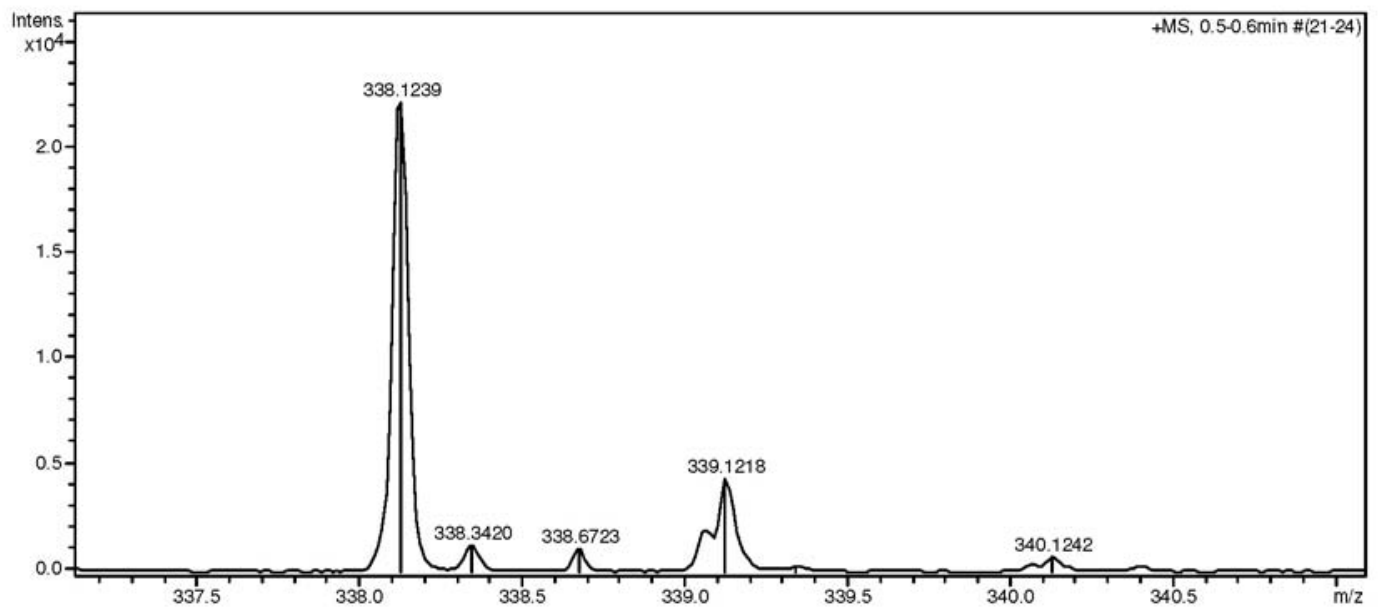

Figure S18. ESI-HRMS spectrum of compound 23.

(2,2-Dimethyl-1,3-dioxolan-4-yl)methyl[2-(hydroxyl(4-nitrophenyl)methyl)] acrylate (24)<smiles>C=C(C(=O)OCC1COC(C)(C)O1)C(O)c1ccc([N+](=O)[O-])cc1</smiles>

${ }^{1} \mathrm{H}$ NMR $\left(\mathrm{CDCl}_{3}, 200 \mathrm{MHz}\right): \delta 1.31(\mathrm{~s}, 3 \mathrm{H}), 1.36(\mathrm{~d}, 3 \mathrm{H}, J 4.0 \mathrm{~Hz}), 3.62-4.33(\mathrm{~m}, 5 \mathrm{H}), 4.44(\mathrm{sl}, 1 \mathrm{H}), 5.64(\mathrm{~d}, 1 \mathrm{H}$, $J 4.2 \mathrm{~Hz}), 5.97(\mathrm{~d}, 1 \mathrm{H}, J 4.8 \mathrm{~Hz}), 6.41(\mathrm{~s}, 1 \mathrm{H}), 7.55(\mathrm{~d}, 2 \mathrm{H}, J 8.4 \mathrm{~Hz}), 8.15(\mathrm{~d}, 2 \mathrm{H}, J 8.6 \mathrm{~Hz}) ;{ }^{13} \mathrm{C} \mathrm{NMR}\left(\mathrm{CDCl}{ }_{3} 50 \mathrm{MHz}\right)$ : $\delta$ 29.1, 30.6, 70.0, 69.9, 75.5, 77.2, 113.8, 127.4, 131.2, 131.5, 145.3, 151.2, 153.2, 169.4; IR (KBr) $\mathrm{v}_{\max } / \mathrm{cm}^{-1}: 3410,3213$, 2985, 2935, 2897, 1716, 1519, 1350, 1157, 1056; ESI-HRMS $(m / z)$ calc. for $\mathrm{C}_{16} \mathrm{H}_{19} \mathrm{NO}_{7}\left[(\mathrm{M}+\mathrm{H})^{+}\right]$338.1195, found 338.1229.

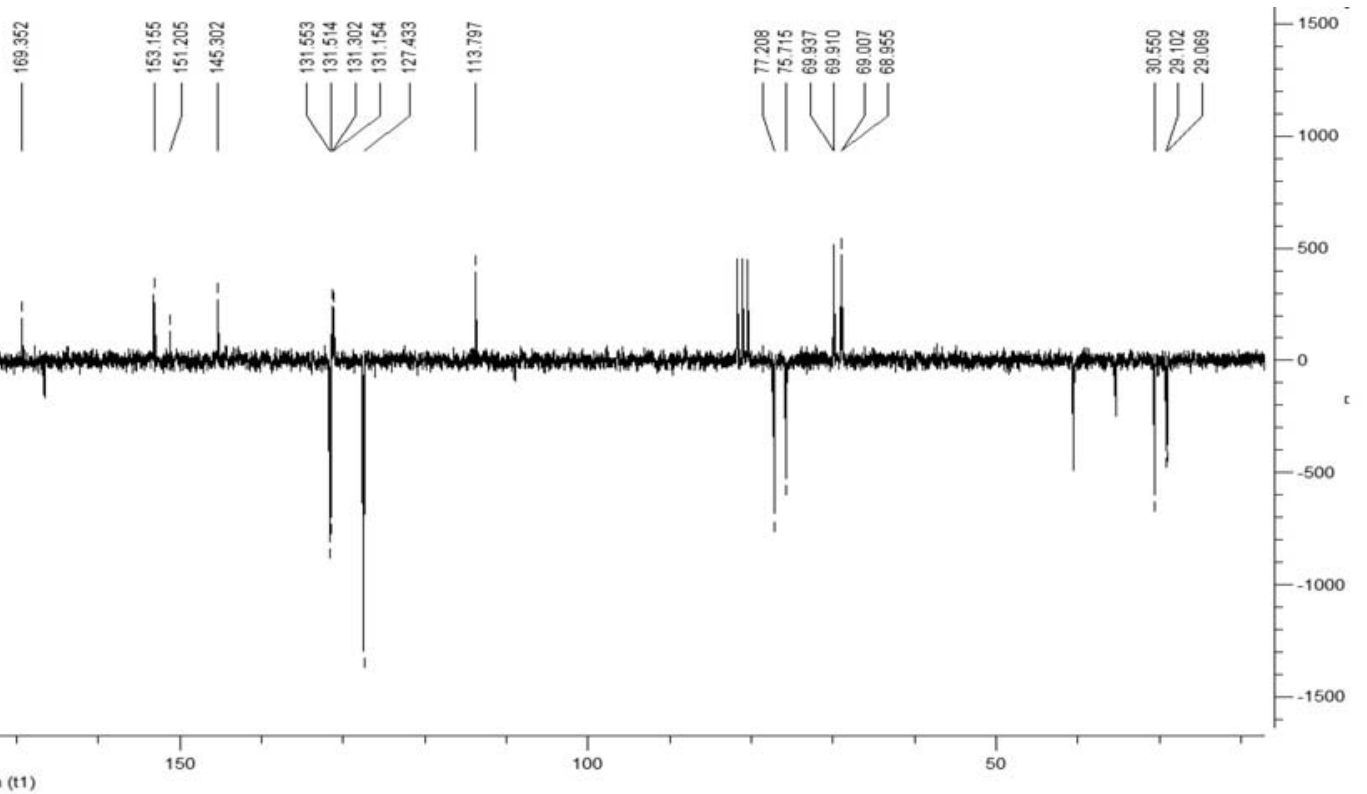

Figure S19. ${ }^{13} \mathrm{C}$ NMR spectrum of compound 24. 


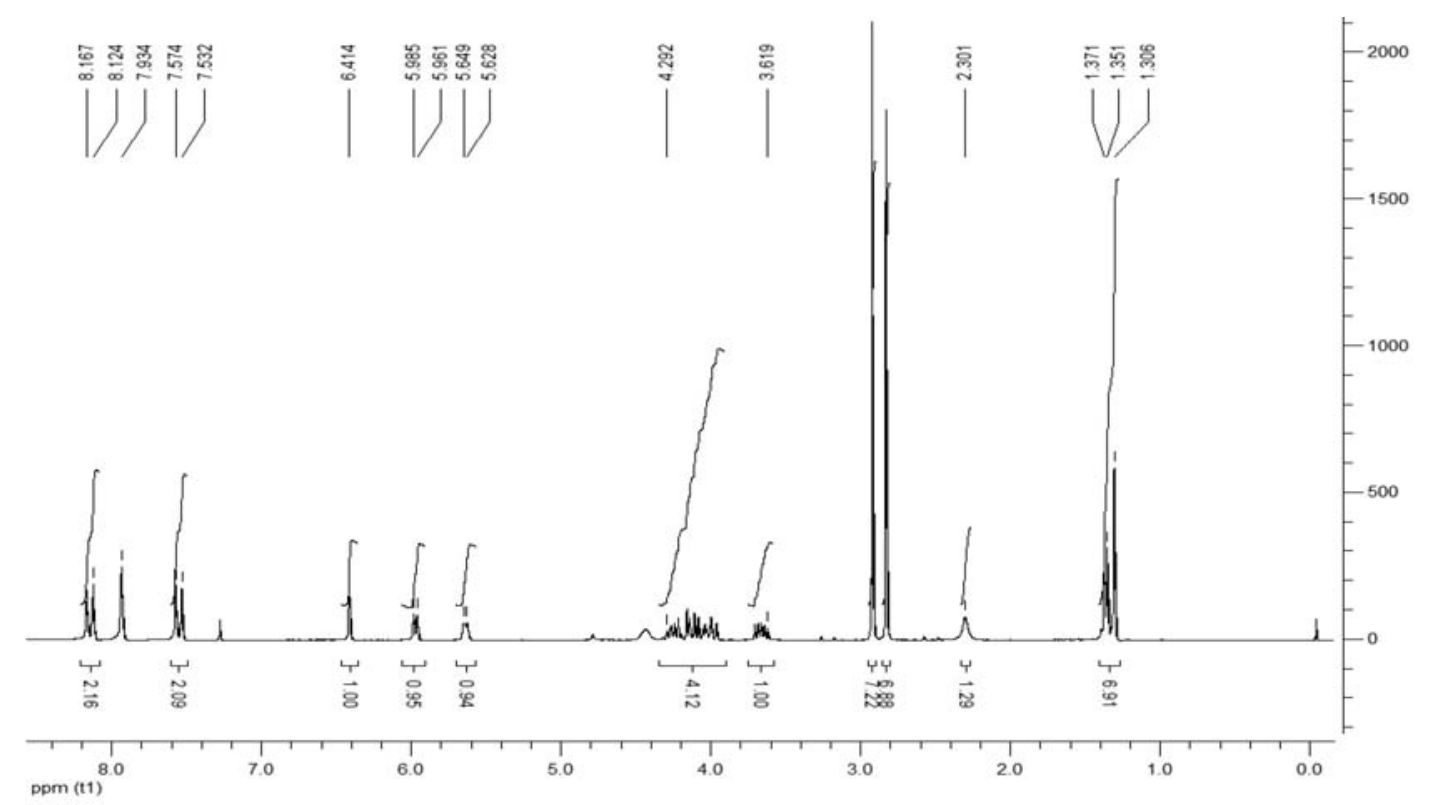

Figure S20. ${ }^{1} \mathrm{H}$ NMR spectrum of compound 24.

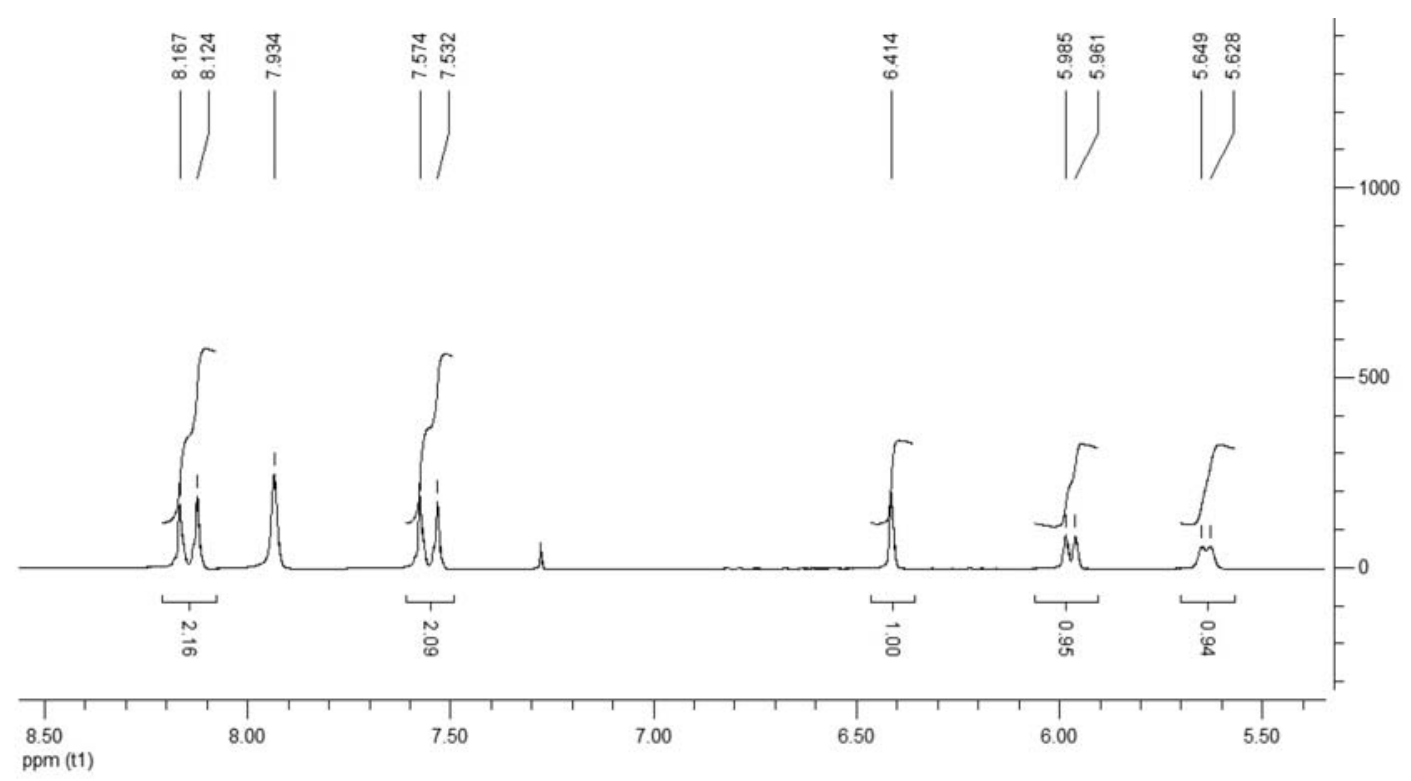

Figure S21. ${ }^{1} \mathrm{H}$ NMR spectrum of compound 24. 


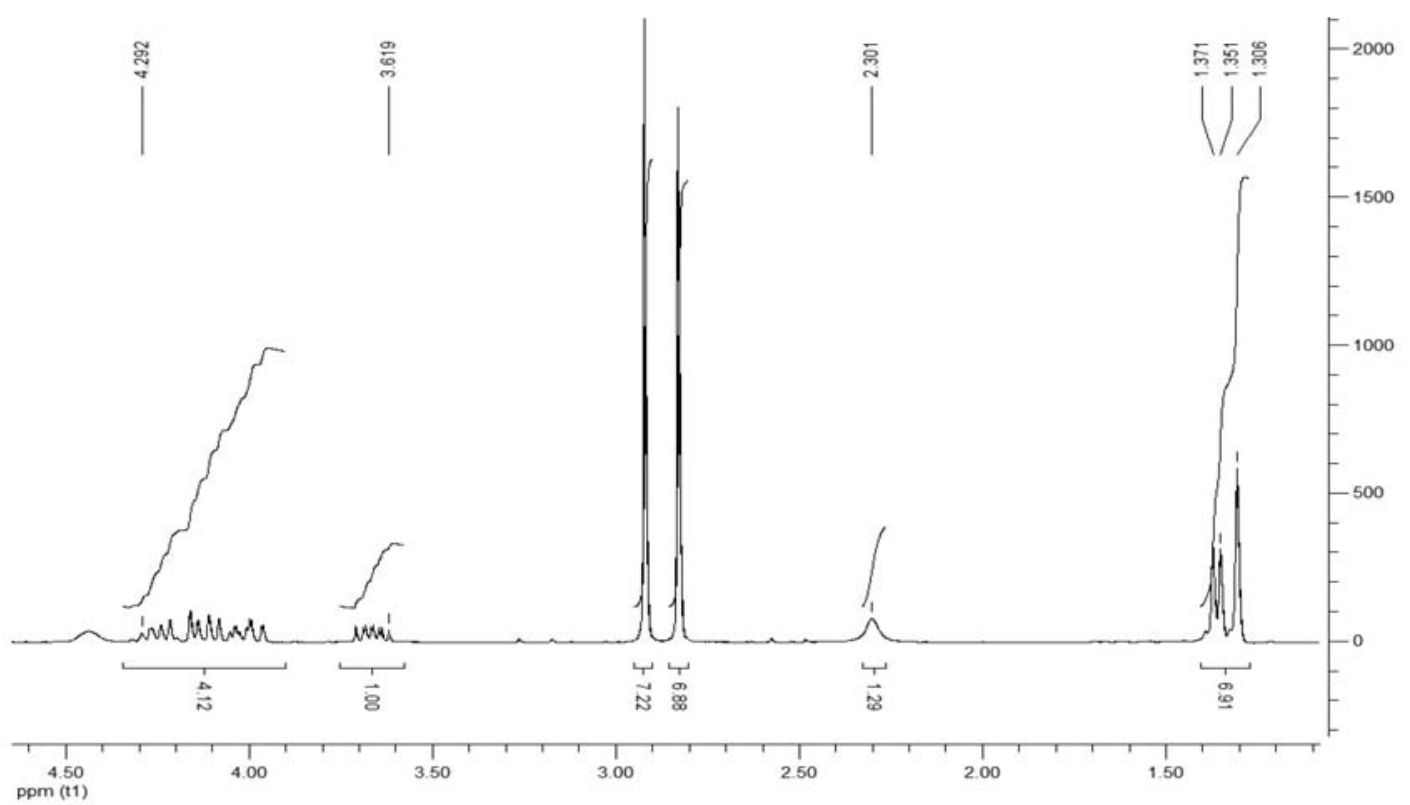

Figure S22. ${ }^{1} \mathrm{H}$ NMR spectrum of compound 24.

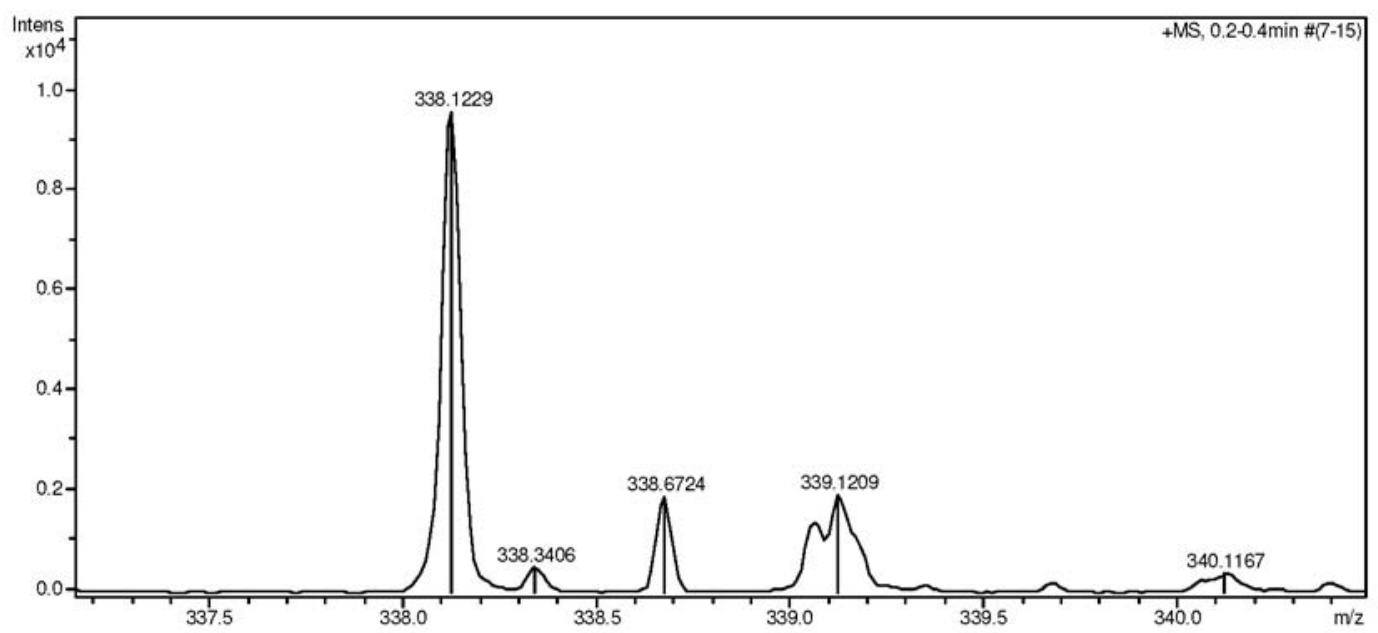

Figure S23. ESI-HRMS spectrum of compound 24.

(2,2-Dimethyl-1,3-dioxolan-4-yl)methyl[2-(hydroxy(pyridin-2-yl)methyl)] acrylate (25)

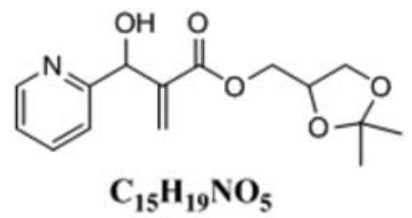

${ }^{1} \mathrm{H} \mathrm{NMR}\left(\mathrm{CDCl}_{3}, 200 \mathrm{MHz}\right): \delta 1.30(\mathrm{~s}, 3 \mathrm{H}), 1.36(\mathrm{~d}, 3 \mathrm{H}, J 3.8 \mathrm{~Hz}), 3.59-4.28(\mathrm{~m}, 5 \mathrm{H}), 4.98(\mathrm{sl}, 1 \mathrm{H}), 5.59(\mathrm{~s}, 1 \mathrm{H}), 5.97$ $(\mathrm{s}, 1 \mathrm{H}), 6.38(\mathrm{~s}, 1 \mathrm{H}), 7.18(\mathrm{~m}, 1 \mathrm{H}), 7.40(\mathrm{~d}, 1 \mathrm{H}, J 8.0 \mathrm{~Hz}), 7.65(\mathrm{td}, 1 \mathrm{H}, J 7.6 / 1.6 \mathrm{~Hz}), 8.49(\mathrm{dd}, 1 \mathrm{H}, J 4.8 / 1.0 \mathrm{~Hz}) ;{ }^{13} \mathrm{C} \mathrm{NMR}$ $\left(\mathrm{CDCl}_{3} 50 \mathrm{MHz}\right): \delta$ 29.2, 30.6, 68.7, 70.2, 76.0, 77.2, 113.7, 125.2, 126.6, 131.5, 140.8, 145.4, 152.1, 163.4, 169.8; IR $(\mathrm{KBr}) \mathrm{v}_{\max } / \mathrm{cm}^{-1}: 3421,2985,2939,2889,1720,1157,1053$; ESI-HRMS $(\mathrm{m} / \mathrm{z})$ calc. for $\mathrm{C}_{15} \mathrm{H}_{19} \mathrm{NO}_{5}\left[(\mathrm{M}+\mathrm{H})^{+}\right] 294.1296$, found 294.1335. 


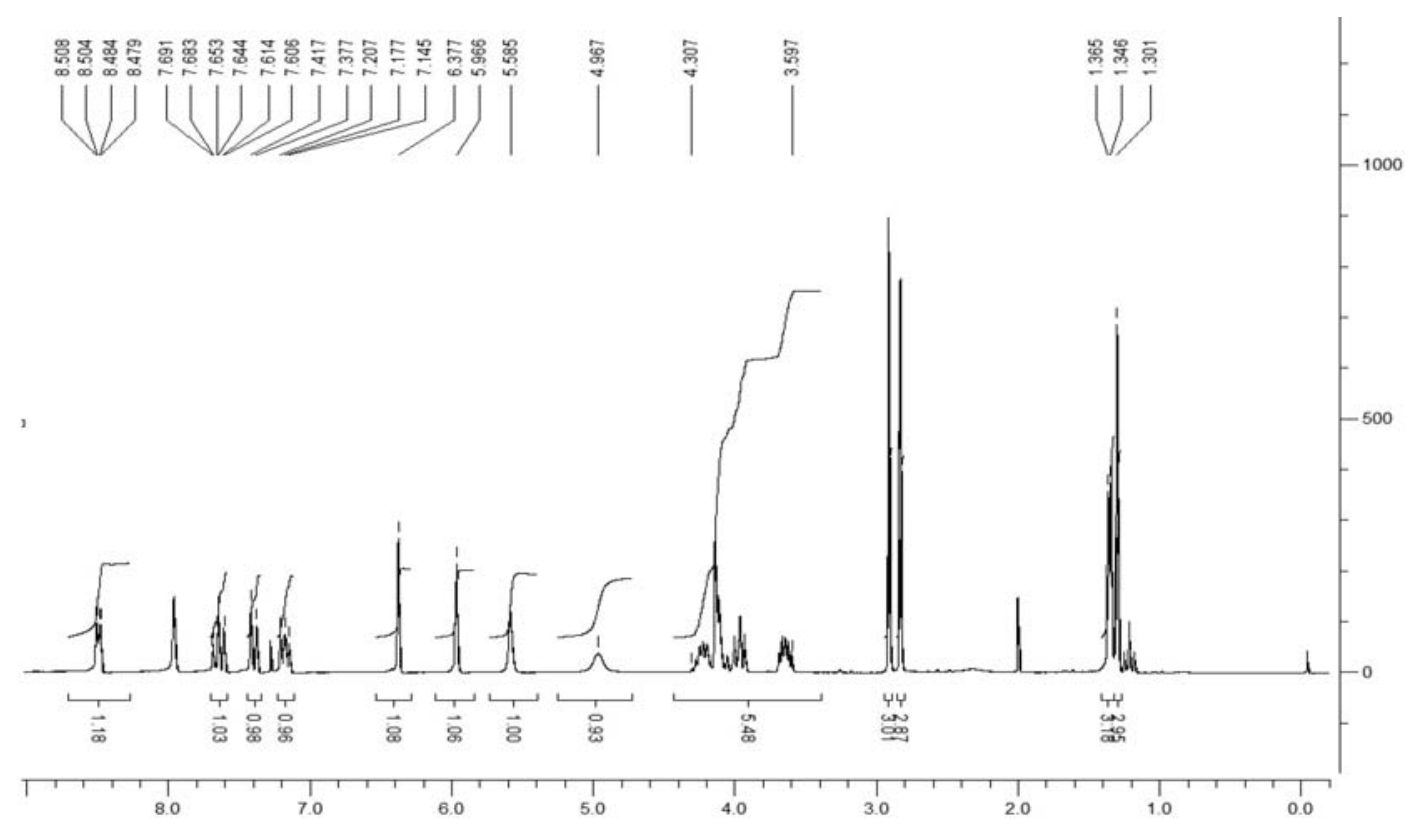

Figure S24. ${ }^{1} \mathrm{H}$ NMR spectrum of compound $\mathbf{2 5}$.

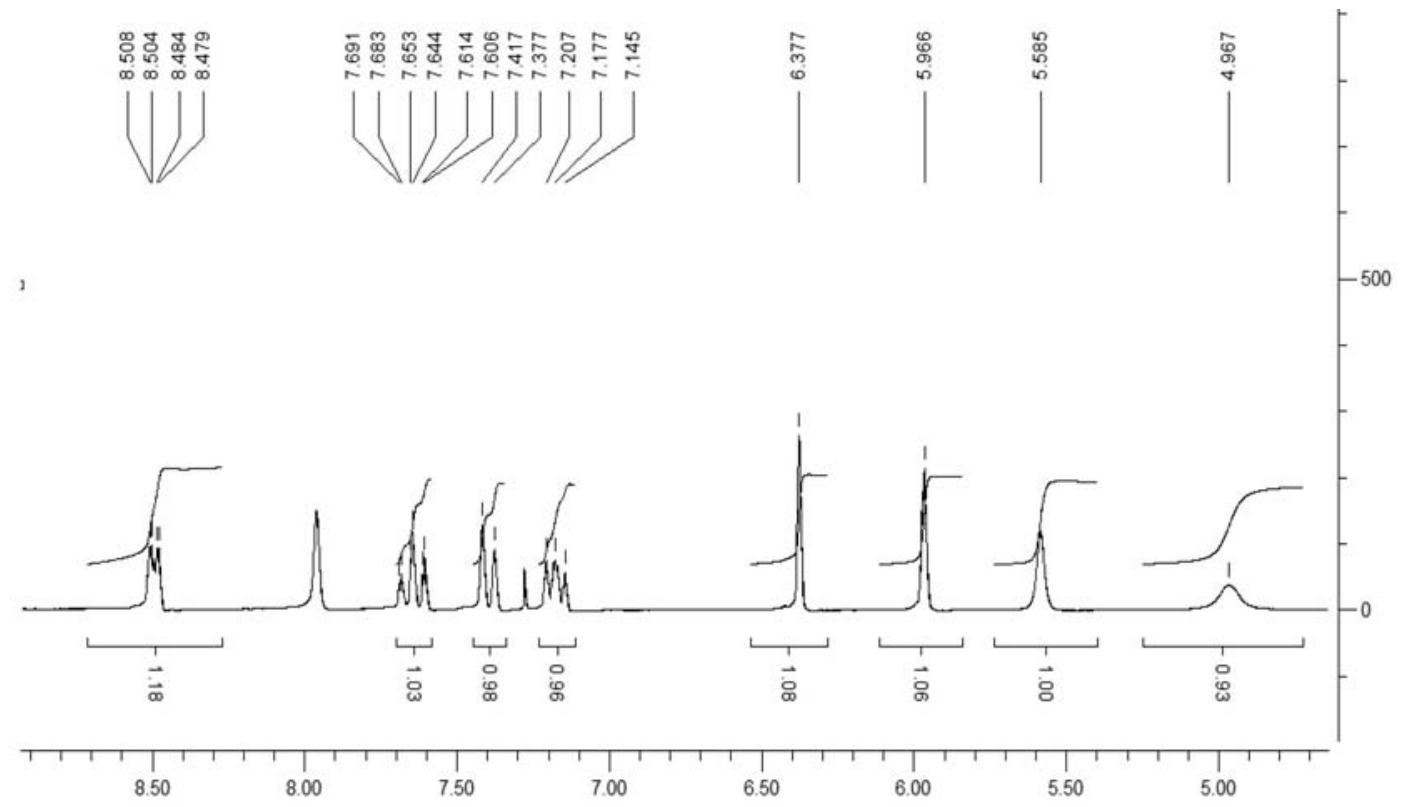

Figure S25. ${ }^{1} \mathrm{H}$ NMR spectrum of compound $\mathbf{2 5}$. 


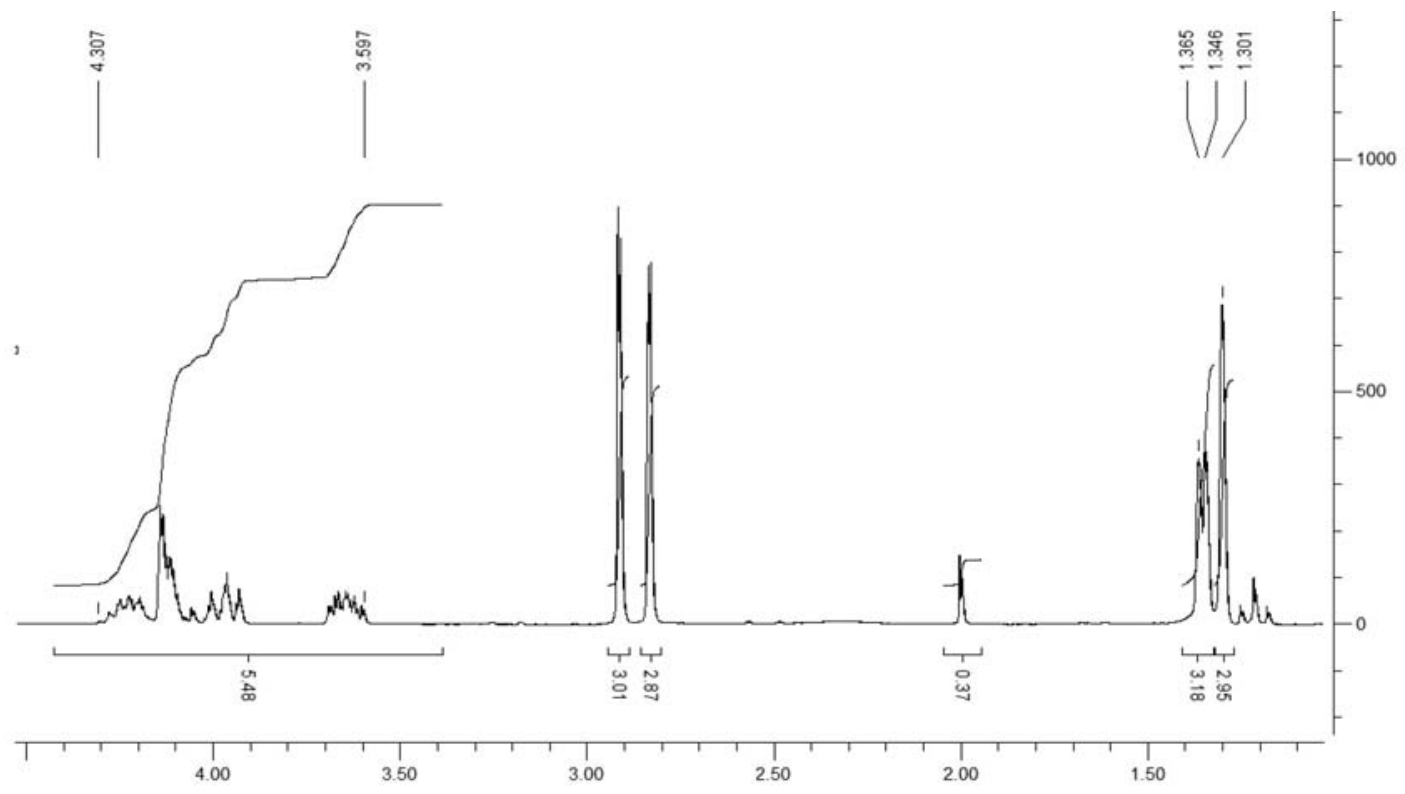

Figure S26. ${ }^{1} \mathrm{H}$ NMR spectrum of compound 25.

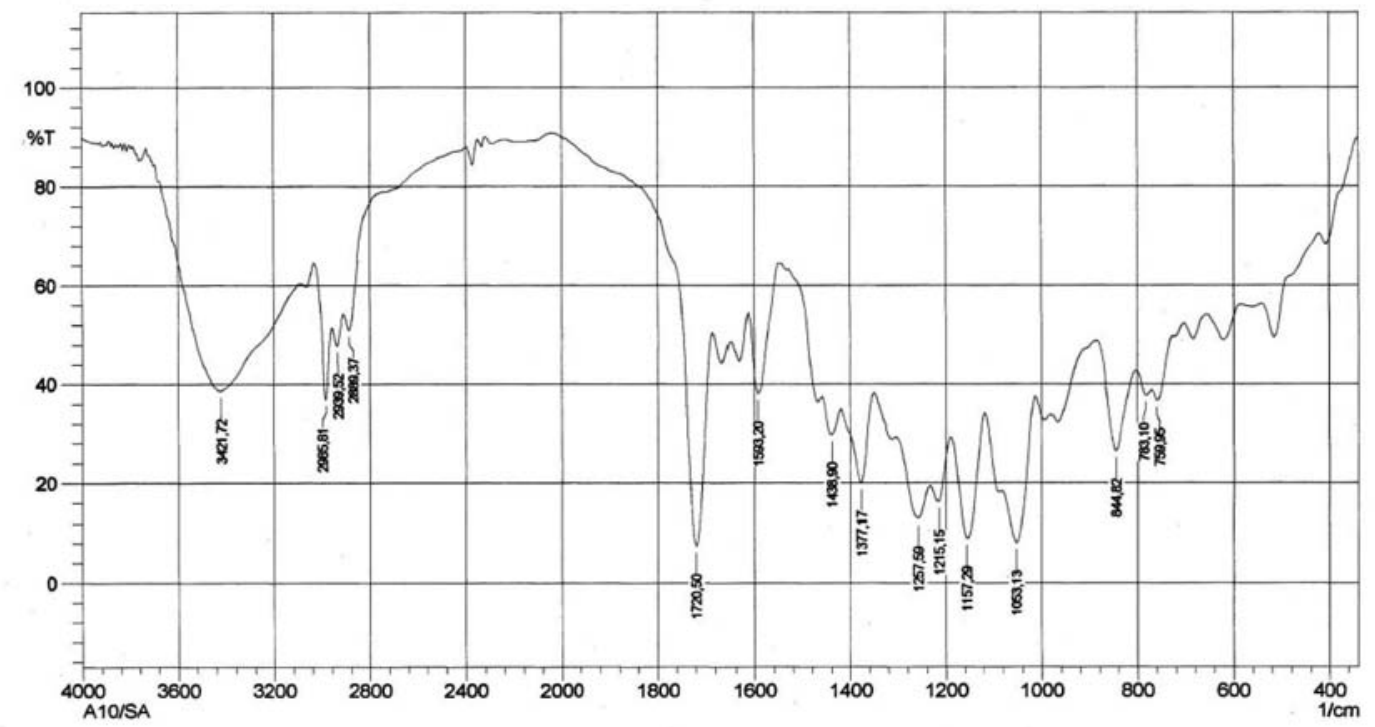

Figure S27. IR spectrum of compound 25. 


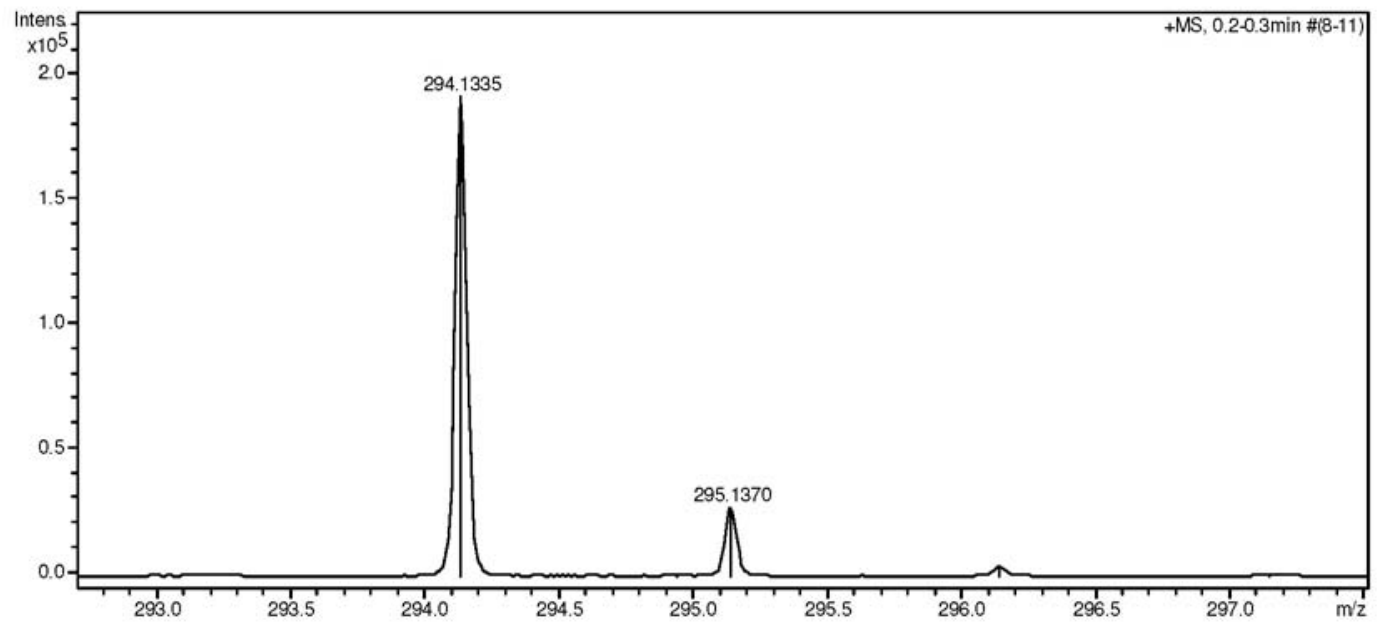

Figure S28. ESI-HRMS spectrum of compound 25.

(2,2-Dimethyl-1,3-dioxolan-4-yl)methyl[2(hydroxyl(pyridin-3-yl)methyl)] acrylate (26)

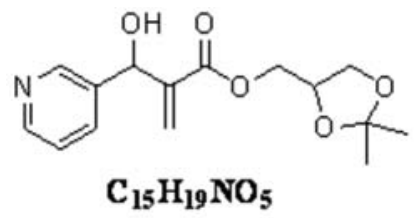

${ }^{1} \mathrm{H}$ NMR $\left(\mathrm{CDCl}_{3}, 200 \mathrm{MHz}\right): \delta 1.32(\mathrm{~s}, 1 \mathrm{H}), 1.38(\mathrm{~d}, 1 \mathrm{H}, J 3.2 \mathrm{~Hz}), 3.58-4.33(\mathrm{~m}, 6 \mathrm{H}), 5.59(\mathrm{~s}, 1 \mathrm{H}), 6.02(\mathrm{~d}, 1 \mathrm{H}, J 3.4 \mathrm{~Hz})$, $6.43(\mathrm{~s}, 1 \mathrm{H}), 7.25(\mathrm{dd}, 1 \mathrm{H}, J$ 8.0/5.0 Hz), $7.72(\mathrm{~d}, 1 \mathrm{H}, J 8.0 \mathrm{~Hz}), 8.38$ (d, 1H, J 4.6 Hz), 8.47 (d, $1 \mathrm{H}, J 2.0 \mathrm{~Hz}) ;{ }^{13} \mathrm{C} \mathrm{NMR}$ $\left(\mathrm{CDCl}_{3} 50 \mathrm{MHz}\right): \delta 29.1,30.6,69.9,70.0,74.3,77.2,113.8,127.4,130.7,141.5,145.4,152.3,152.5,169.4 ; \mathrm{IR}(\mathrm{KBr})$ $v_{\max } / \mathrm{cm}^{-1}: 3124,2989,2877,1716,1145,1060$; ESI-HRMS $(m / z)$ calc. for $\mathrm{C}_{15} \mathrm{H}_{19} \mathrm{NO}_{5}\left[(\mathrm{M}+\mathrm{H})^{+}\right] 294.1296$, found 294.1337 .

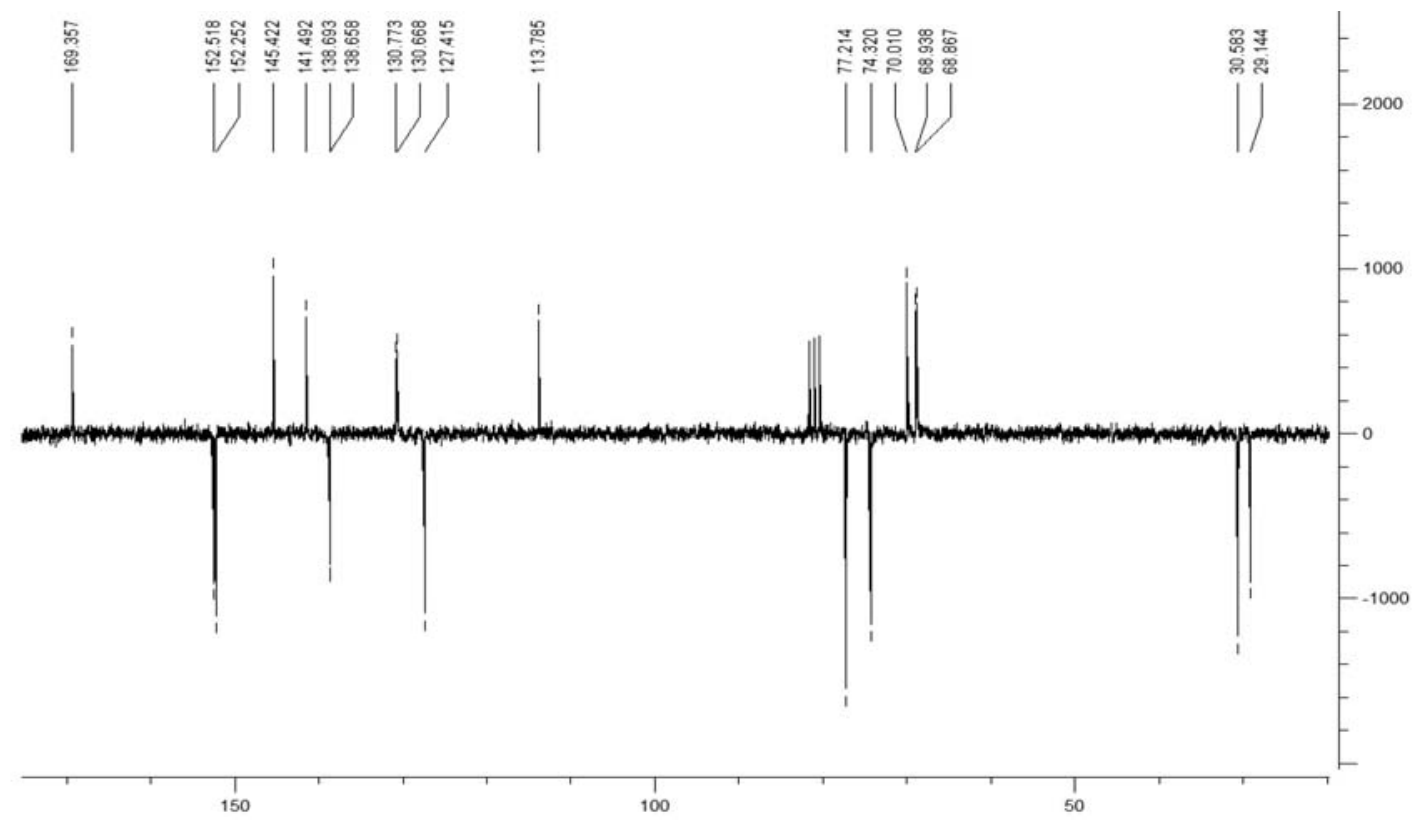

Figure S29. ${ }^{13} \mathrm{C}$ NMR spectrum of compound 26. 


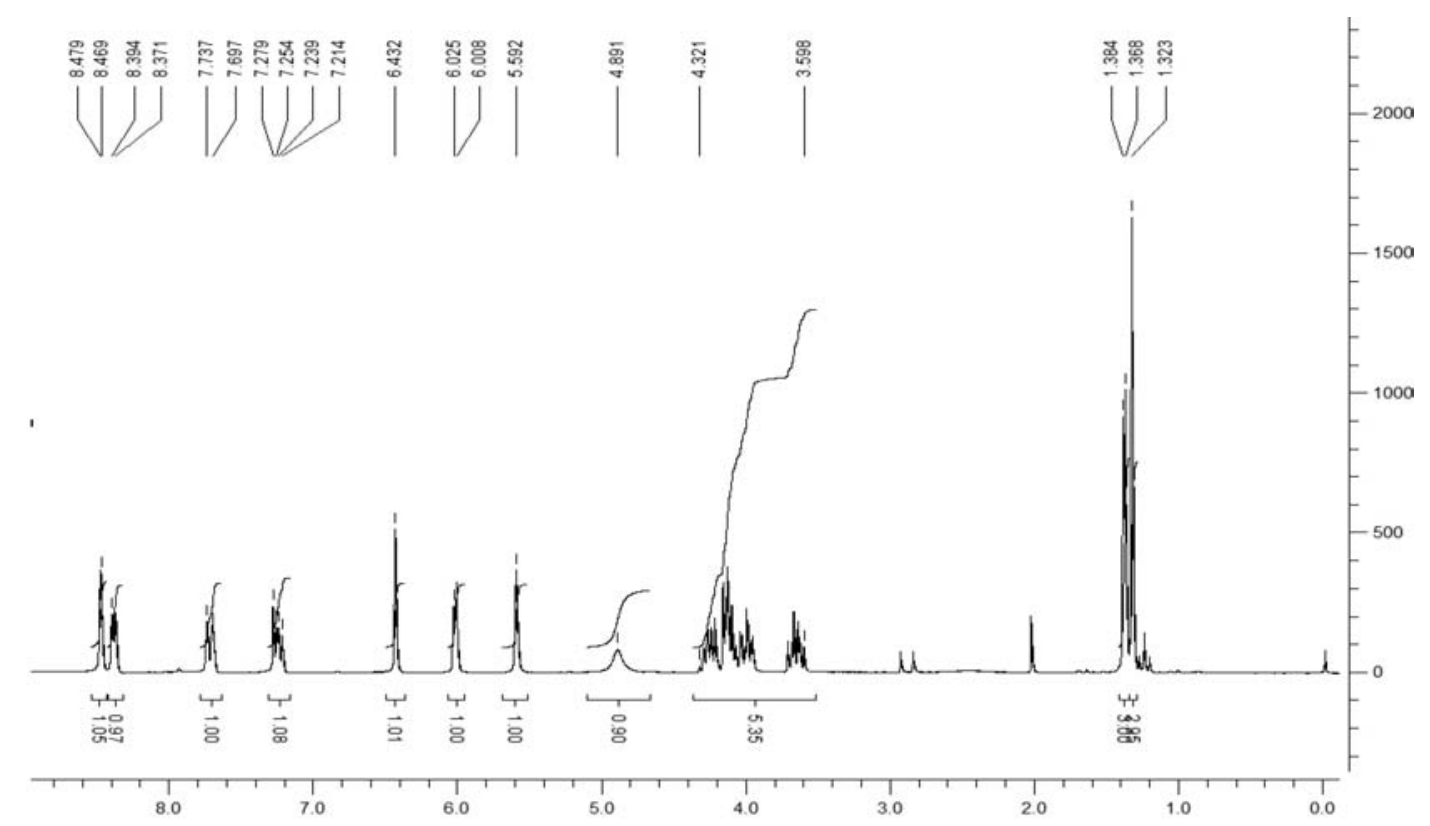

Figure S30. ${ }^{1} \mathrm{H}$ NMR spectrum of compound 26.

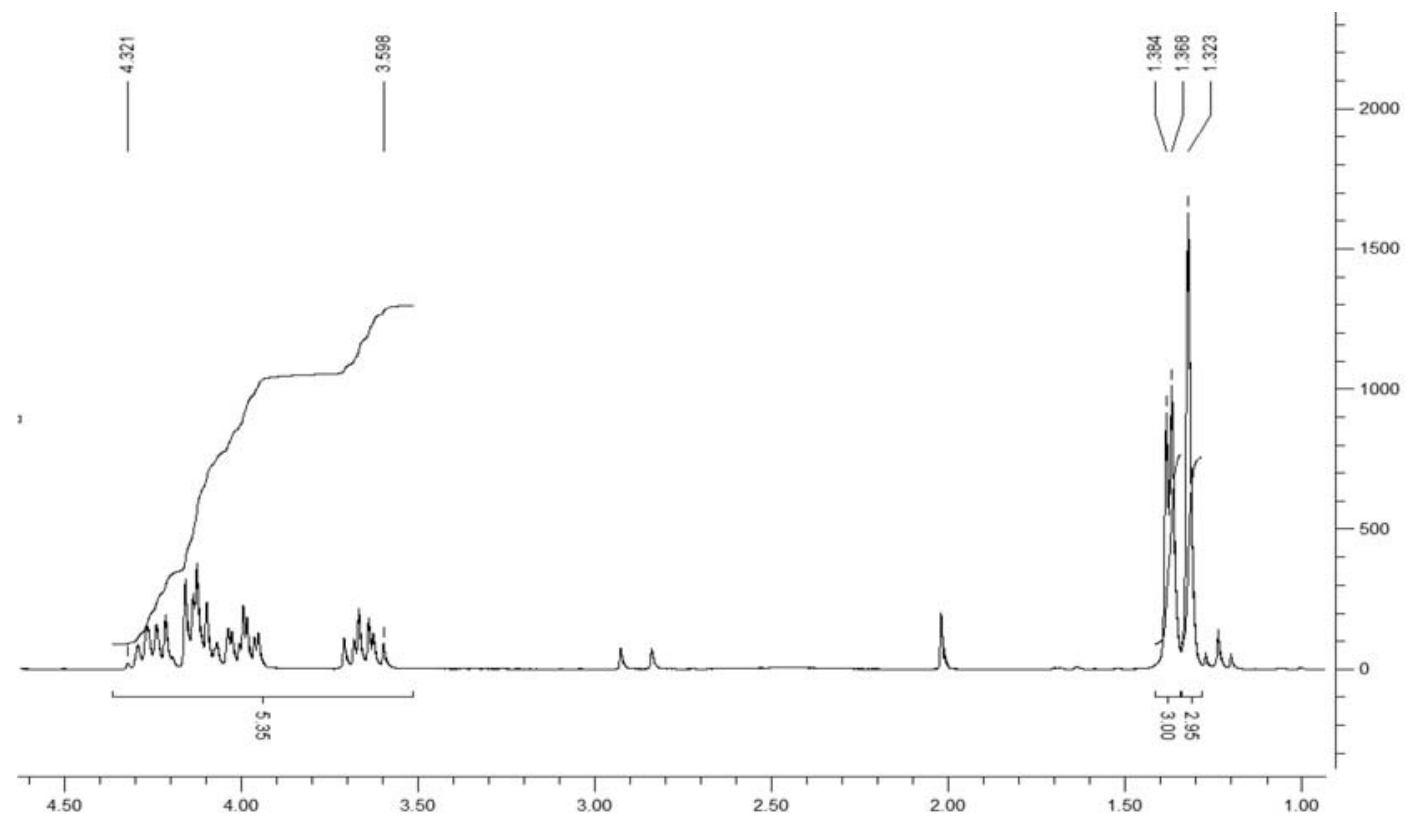

Figure S31. ${ }^{1} \mathrm{H}$ NMR spectrum of compound 26. 


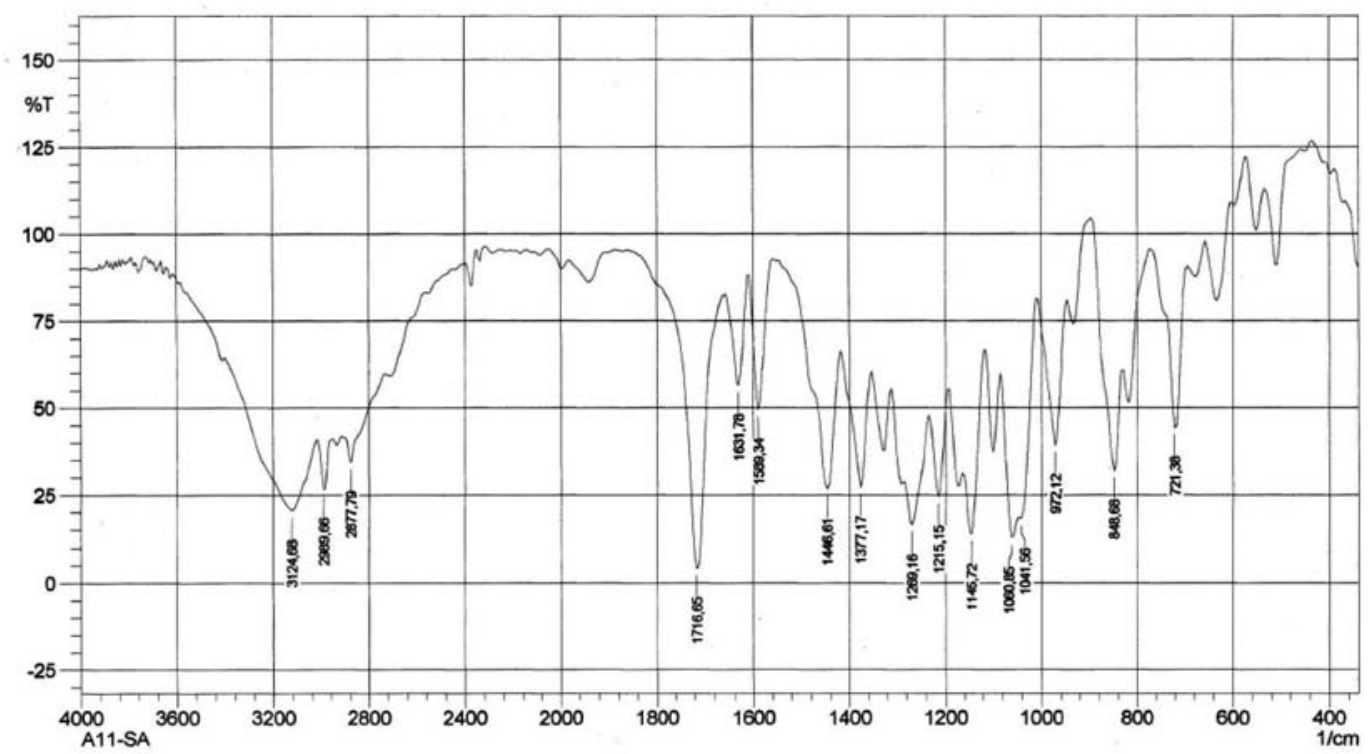

Figure S32. IR spectrum of compound 26.

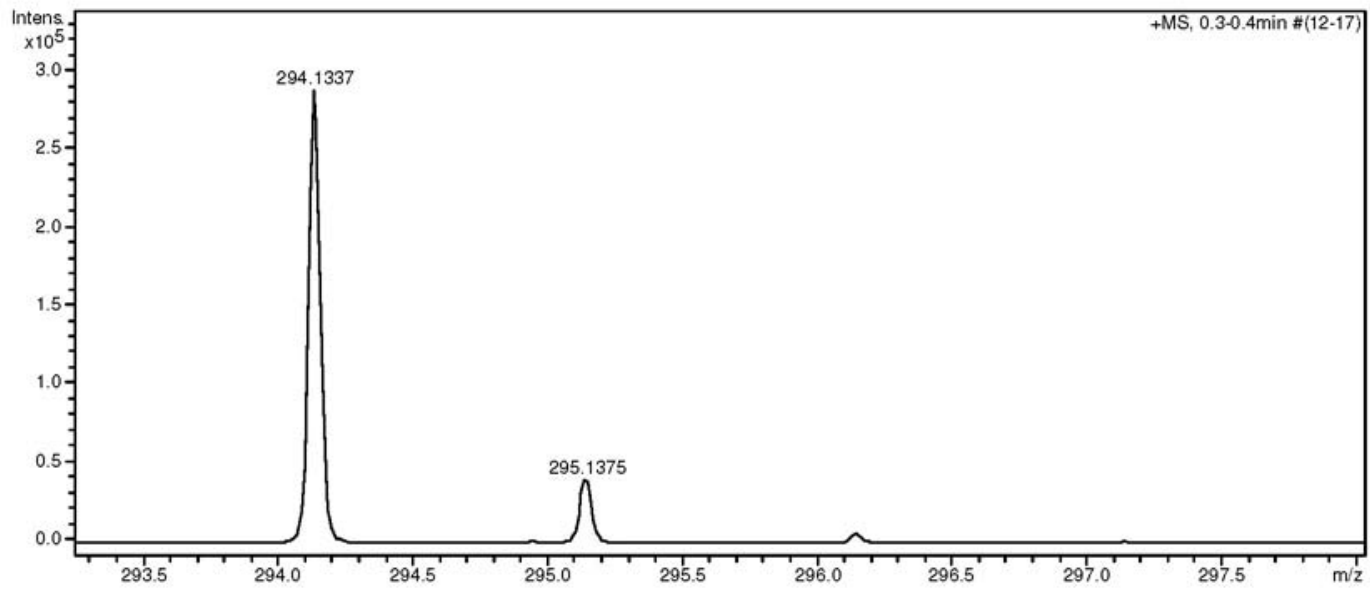

Figure S33. ESI-HRMS spectrum of compound 26. 
(2,2-Dimethyl-1,3-dioxolan-4-yl)methyl[2-(hydroxyl(pyridin-4-yl)methyl)] acrylate (27)<smiles>C=C(C(=O)OCC1COC(C)(C)O1)C(O)c1ccncc1</smiles>

${ }^{1} \mathrm{H} \mathrm{NMR}\left(\mathrm{CDCl}_{3}, 200 \mathrm{MHz}\right): \delta 1.34(\mathrm{~s}, 3 \mathrm{H}), 1.39(\mathrm{~d}, 3 \mathrm{H}, J 4.2 \mathrm{~Hz}), 3.63-4.35(\mathrm{~m}, 6 \mathrm{H}), 5.55(\mathrm{~s}, 1 \mathrm{H}), 5.96(\mathrm{~d}, 1 \mathrm{H}, J 4.6 \mathrm{~Hz})$, $6.44(\mathrm{~s}, 1 \mathrm{H}), 7.33(\mathrm{~d}, 2 \mathrm{H}, J 6 \mathrm{~Hz}), 8.46(\mathrm{~d}, 2 \mathrm{H}, J 4.8) ;{ }^{13} \mathrm{C} \mathrm{NMR}\left(\mathrm{CDCl}_{3} 50 \mathrm{MHz}\right): \delta 29.1,30.6,69.0,69.9,75.5,77.2,113.8$, 125.5, 131.6, 145.0, 153.4, 155.1, 169.4; IR (KBr) $v_{\max } / \mathrm{cm}^{-1}: 3140,2989,2877,1716,1141,1056$; ESI-HRMS $(\mathrm{m} / \mathrm{z})$ calc. for $\mathrm{C}_{15} \mathrm{H}_{19} \mathrm{NO}_{5}\left[(\mathrm{M}+\mathrm{H})^{+}\right]$294.1296, found 294,1337.

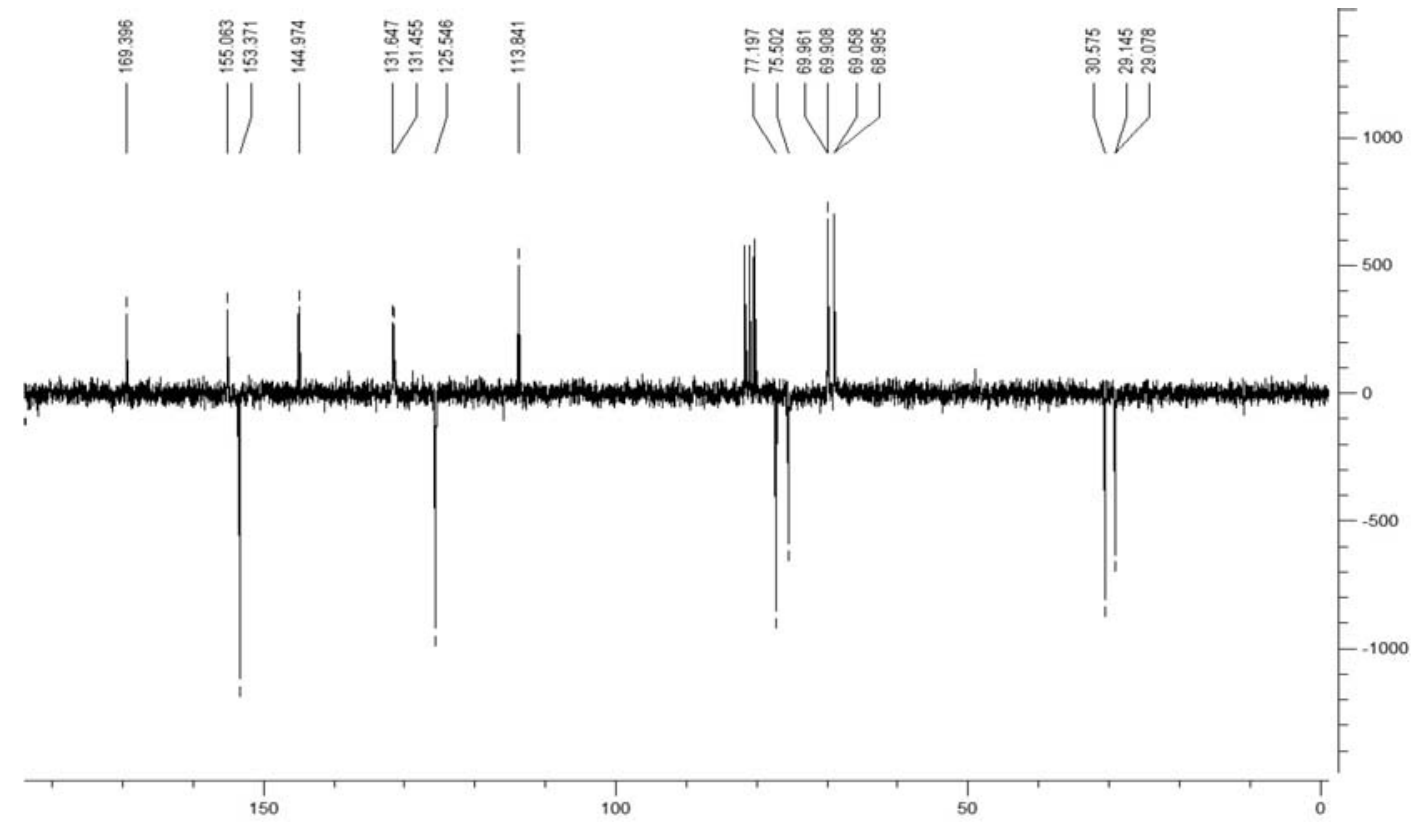

Figure S34. ${ }^{13} \mathrm{C}$ NMR spectrum of compound 27.

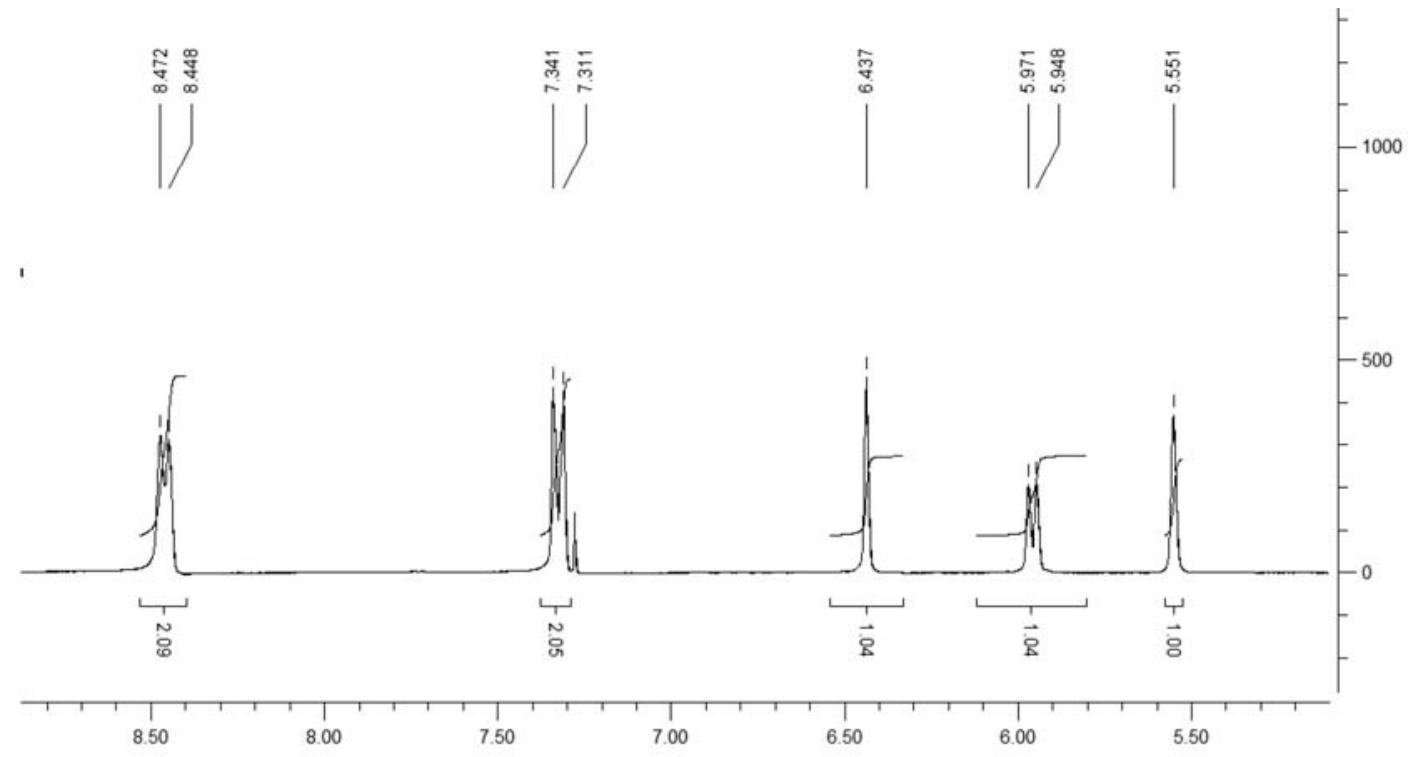

Figure S35. ${ }^{1} \mathrm{H}$ NMR spectrum of compound 27. 


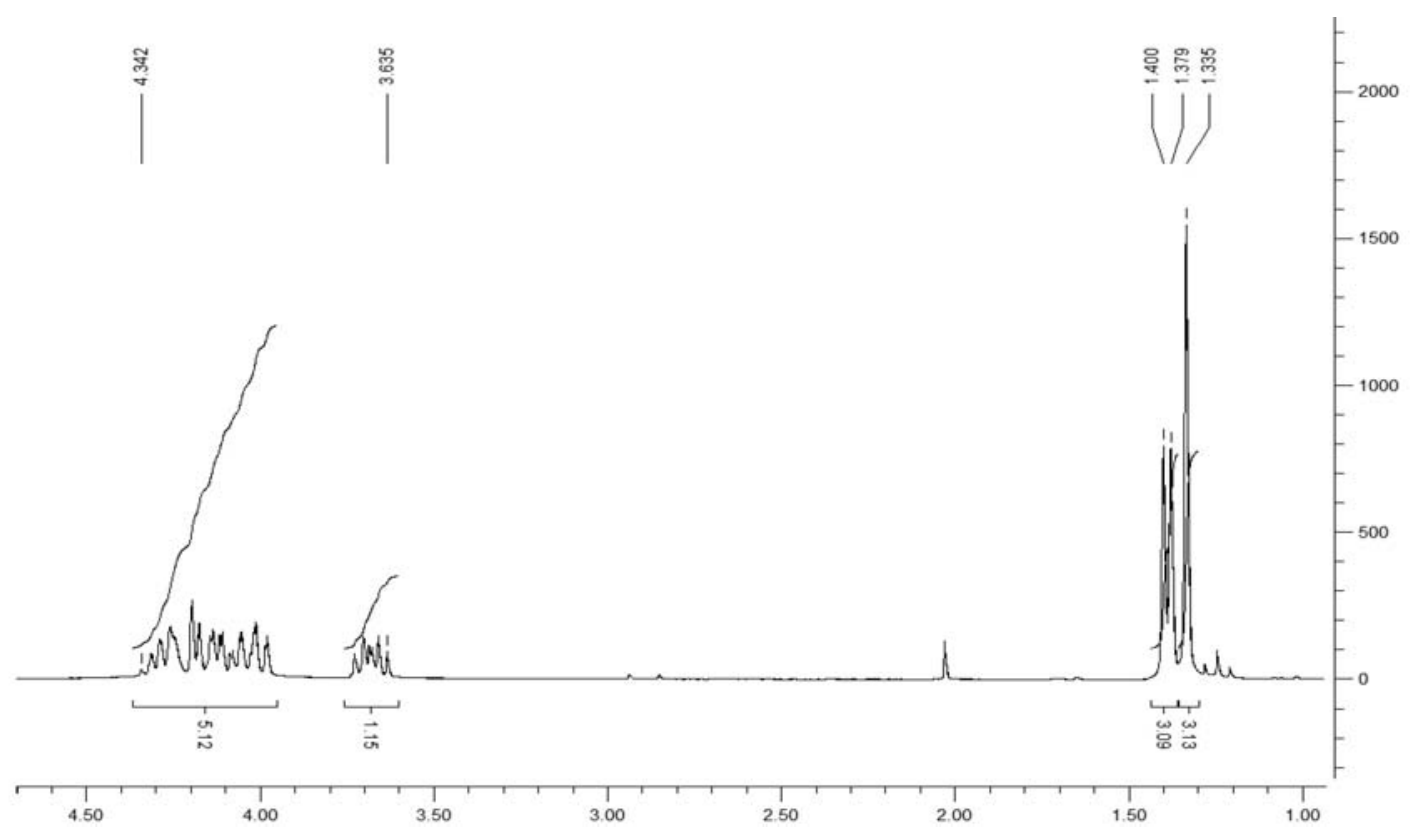

Figure S36. ${ }^{1} \mathrm{H}$ NMR spectrum of compound 27.

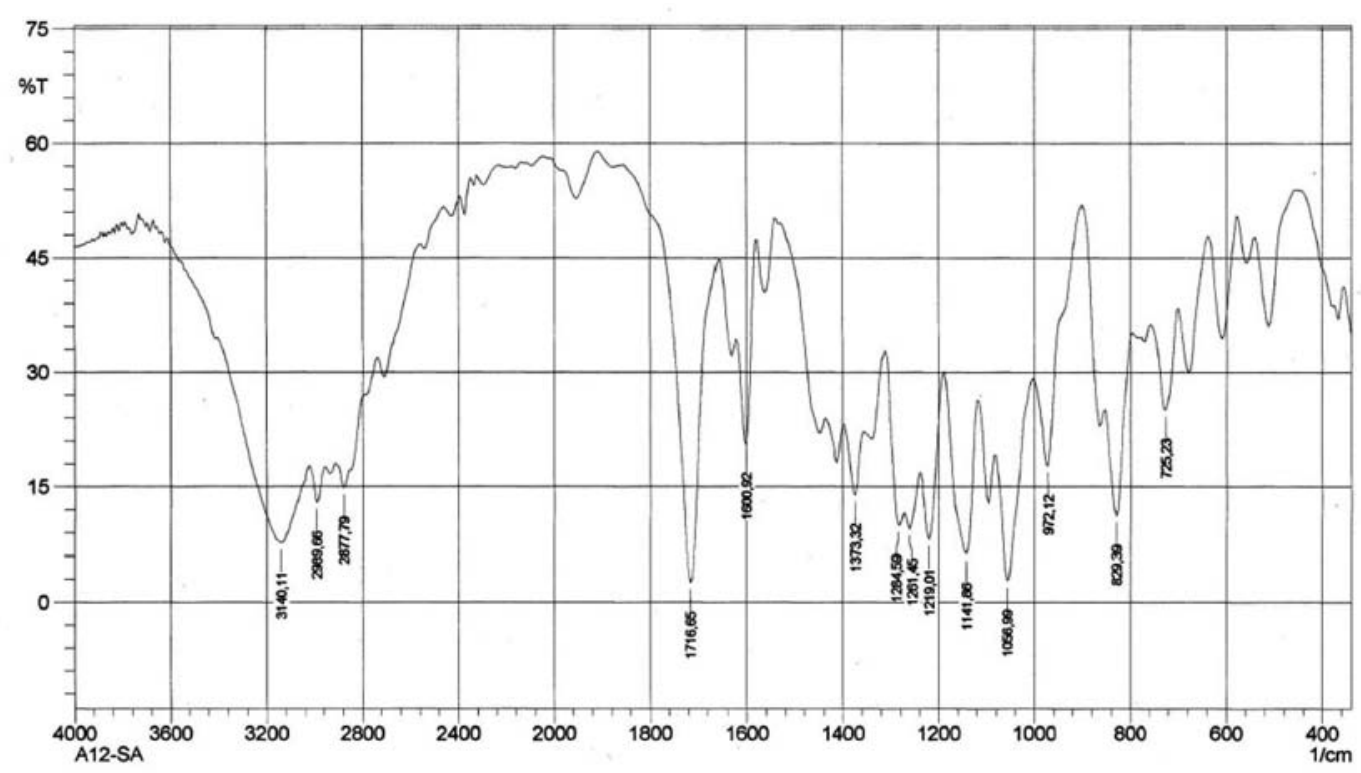

Figure S37. IR spectrum of compound 27. 


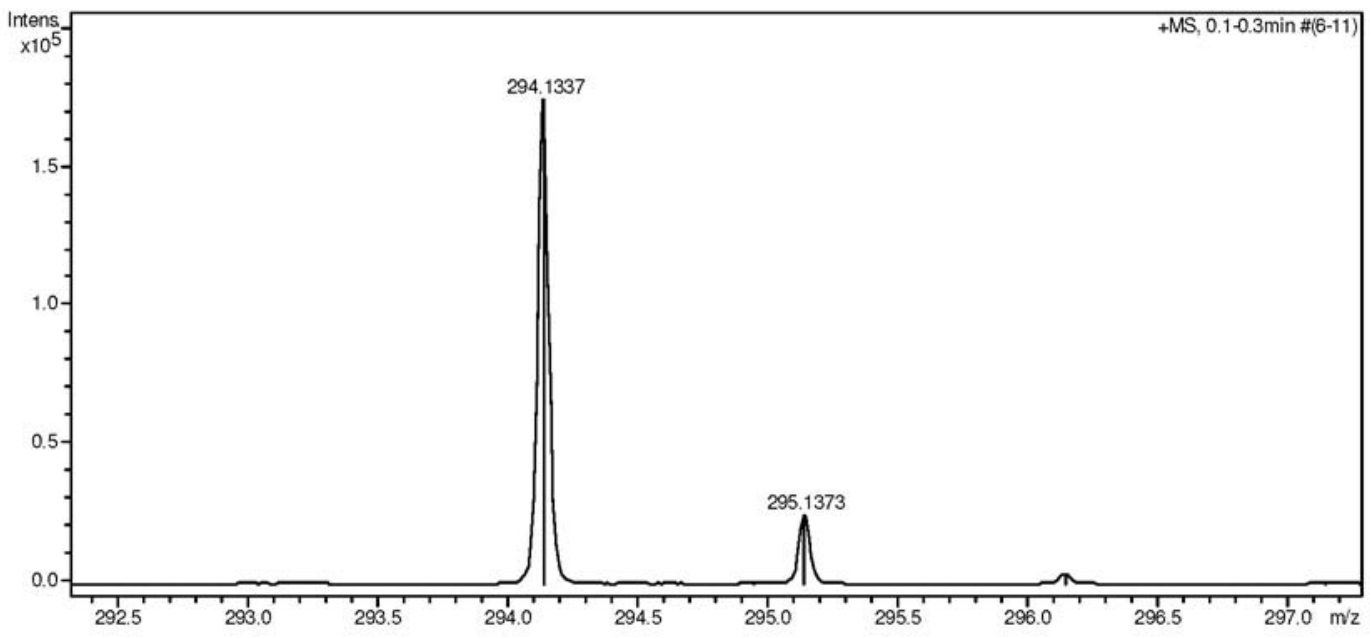

Figure S38. ESI-HRMS spectrum of compound 27.

\section{2,3-Dihydroxypropyl[2-(hydroxyl(2-nitrophenyl)methyl)] acrylate (8)}<smiles>C=C(C(=O)OCC(O)CO)C(O)c1ccccc1[N+](=O)[O-]</smiles>

${ }^{1} \mathrm{H}$ NMR (MeOD, $\left.300 \mathrm{MHz}\right): \delta 3.35$ (s, 3H), 3.46-3.55 (m, 2H), 3.79-3.86 (m, 1H), 4.13-4.23 (m, 2H), 5.72-5.74 (m, $1 \mathrm{H}), 6.26(\mathrm{~s}, 1 \mathrm{H}), 6.37(\mathrm{~s}, 1 \mathrm{H}), 7.48-7.54(\mathrm{~m}, 1 \mathrm{H}), 7.66-7.72(\mathrm{~m}, 1 \mathrm{H}), 7.77(\mathrm{~d}, 1 \mathrm{H}, J 7.8 \mathrm{~Hz}), 7.94(\mathrm{~d}, 1 \mathrm{H}, J 8.1 \mathrm{~Hz}) ;{ }^{13} \mathrm{C} \mathrm{NMR}$ (MeOH, $75 \mathrm{MHz}): \delta$ 64.2, 67.0, 67.6, 71.1, 124.5, 126.4, 129.3, 129.8, 134.3, 138.4, 144.2, 167.1; IR (KBr) $v_{\text {max }} / \mathrm{cm}^{-1}: 3383$, $1712,1527,1350,1265,1157,1120,1045$; ESI-HRMS $(\mathrm{m} / \mathrm{z})$ calc. for $\mathrm{C}_{13} \mathrm{H}_{15} \mathrm{NO}_{7}\left[(\mathrm{M}+\mathrm{Na})^{+}\right] 320.0746$, found 320.0748 .

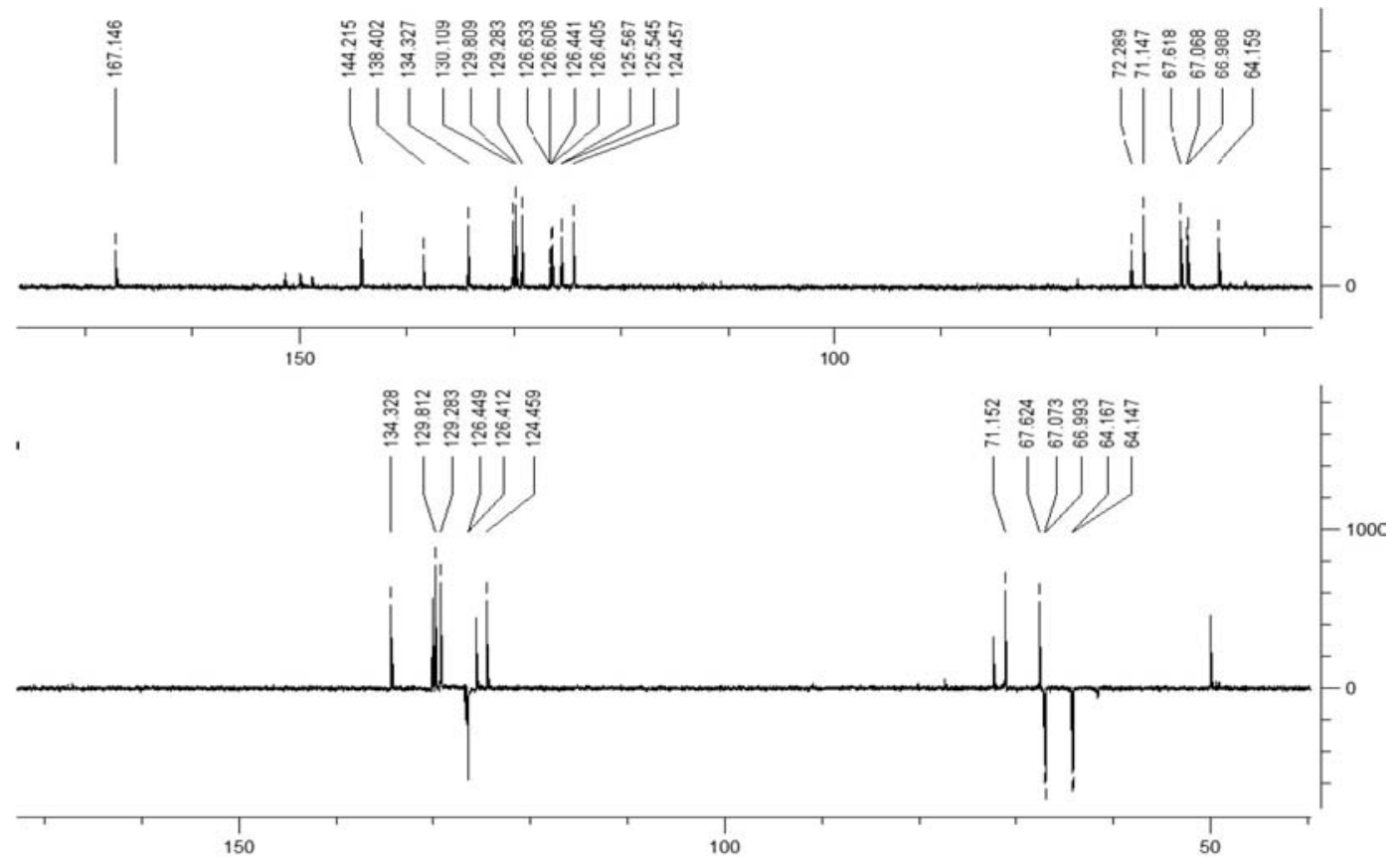

Figure S39. ${ }^{13} \mathrm{C}$ NMR spectrum of compound 8 . 


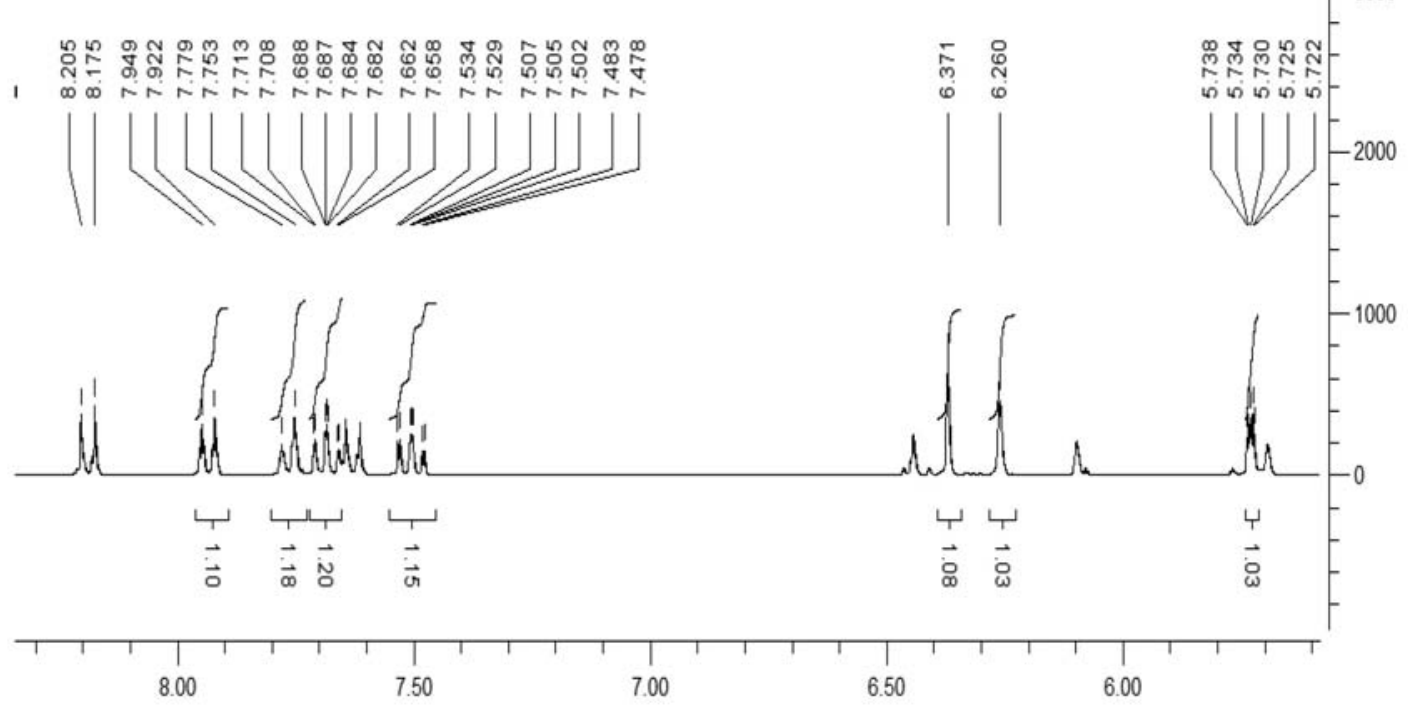

Figure S40. ${ }^{1} \mathrm{H}$ NMR spectrum of compound $\mathbf{8}$.

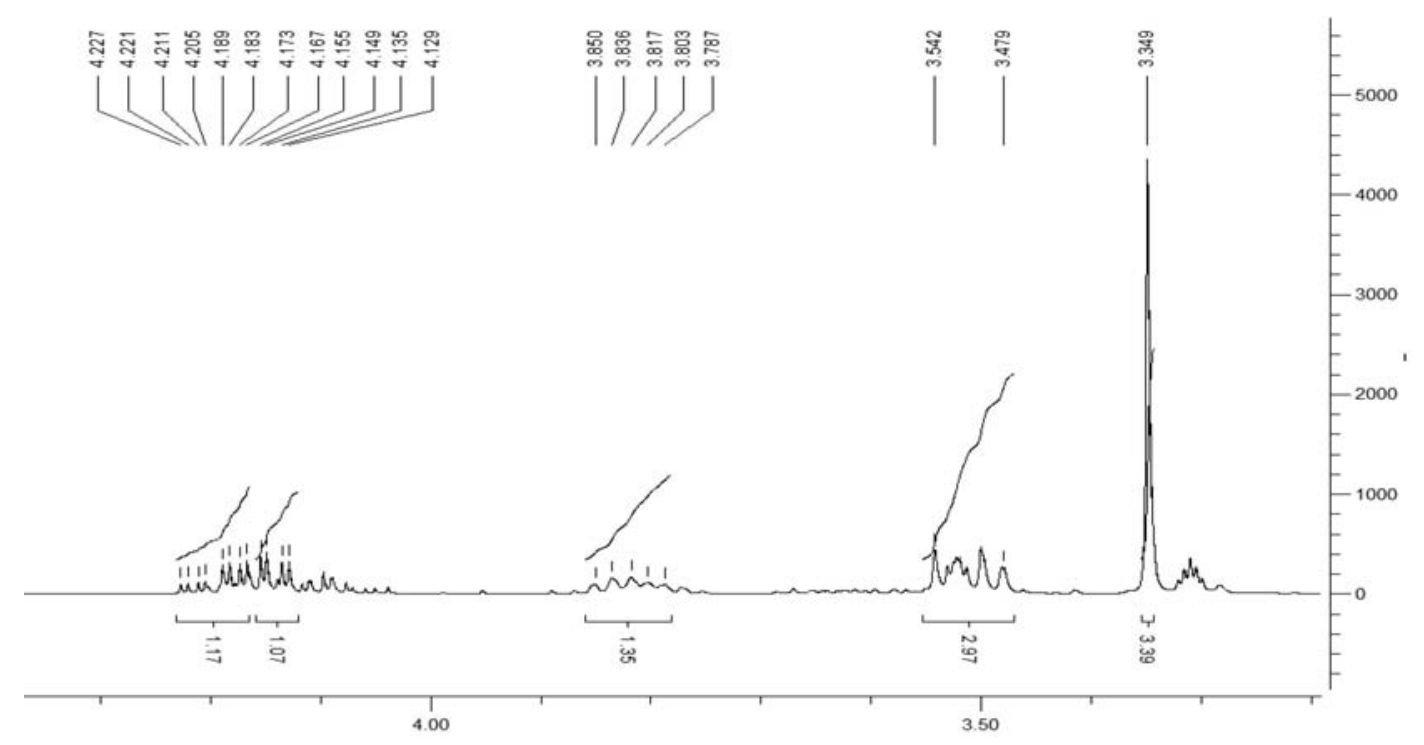

Figure S41. ${ }^{1} \mathrm{H}$ NMR spectrum of compound 8. 


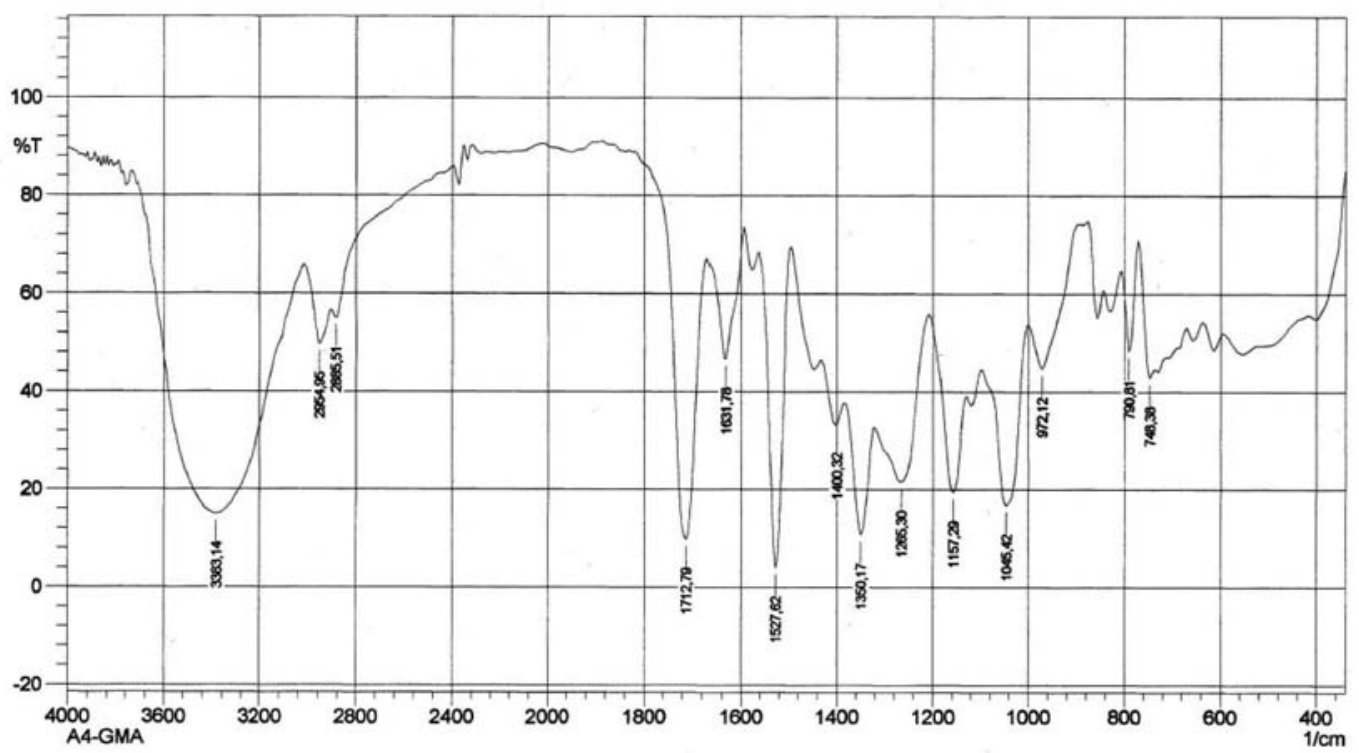

Figure S42. IR spectrum of compound 8 .

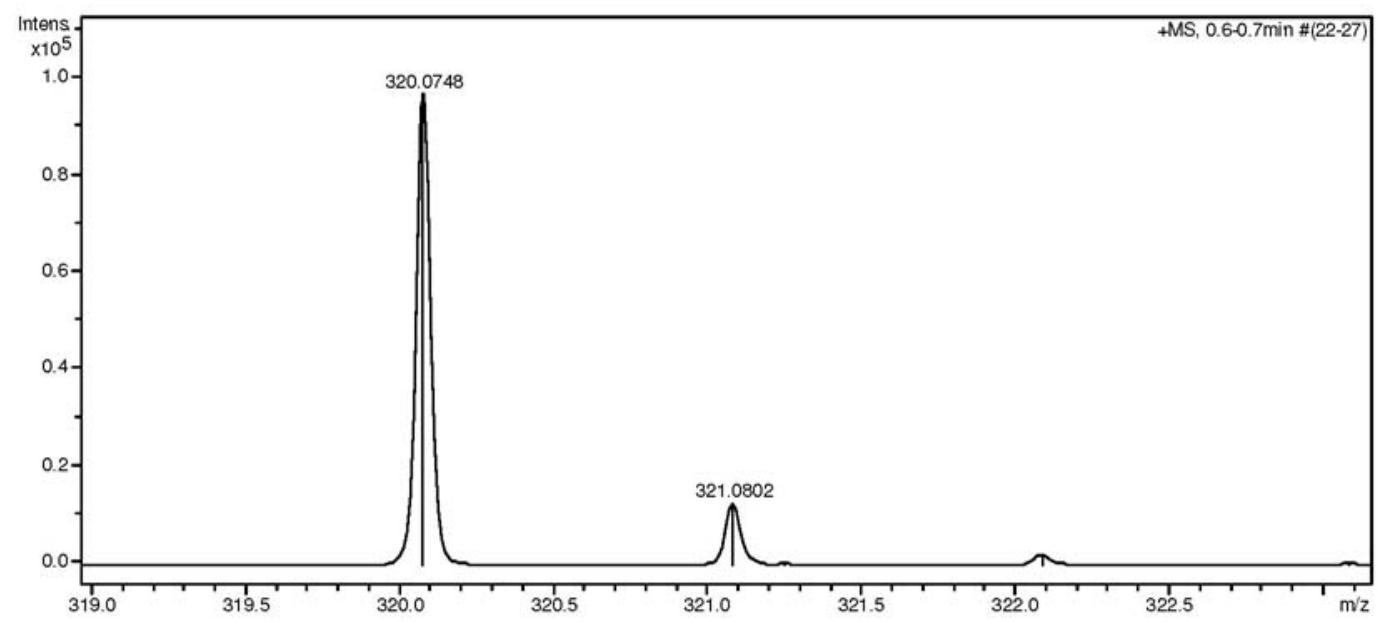

Figure S43. ESI-HRMS spectrum of compound 8. 
2,3-Dihydroxypropyl[2-(hydroxyl(3-nitrophenyl)methyl)] acrylate (9)<smiles>C=C(C(=O)OCC(O)CO)C(O)c1cccc([N+](=O)[O-])c1</smiles>

${ }^{1} \mathrm{H}$ NMR (MeOD, $\left.300 \mathrm{MHz}\right): \delta 3.35$ (s, 2H), 3.49 (d, 2H, J 5.4 Hz), 3.75-3.83 (m, 1H), 4.07 (ddd, 1H, J 11.4/6.0/4.2 Hz), $4.17(\mathrm{ddd}, 1 \mathrm{H}, J 11.4 / 4.5 / 3.0 \mathrm{~Hz}), 5.70(\mathrm{~s}, 1 \mathrm{H}), 6.13(\mathrm{dd}, 1 \mathrm{H}, J 2.1 / 1.5 \mathrm{~Hz}), 6.46(\mathrm{dd}, 1 \mathrm{H}, J 2.4 / 1.2 \mathrm{~Hz}), 7.56(\mathrm{t}, 1 \mathrm{H}, J 8.1 \mathrm{~Hz})$, 7.77-7.81 (m, 1H), $8.13\left(\mathrm{ddd}, 1 \mathrm{H}, J\right.$ 8.1/2.1/0.9 Hz), $8.26(\mathrm{t}, 1 \mathrm{H}, J 1.8 \mathrm{~Hz}) ;{ }^{13} \mathrm{C} \mathrm{NMR}(\mathrm{MeOH}, 75 \mathrm{MHz}): \delta 64.1,67.0,71.1$, 72.2, 123.0, 123.5, 126.5, 130.6, 134.6, 144.3, 146.4, 149.7, 167.0; IR (KBr) $v_{\max } / \mathrm{cm}^{-1}: 3375,1708,1527,1350,1273,1157$, 1095, 1049; ESI-HRMS $(\mathrm{m} / \mathrm{z})$ calc. for $\mathrm{C}_{13} \mathrm{H}_{15} \mathrm{NO}_{7}\left[(\mathrm{M}+\mathrm{Na})^{+}\right]$320.0746, found 320.0749 .

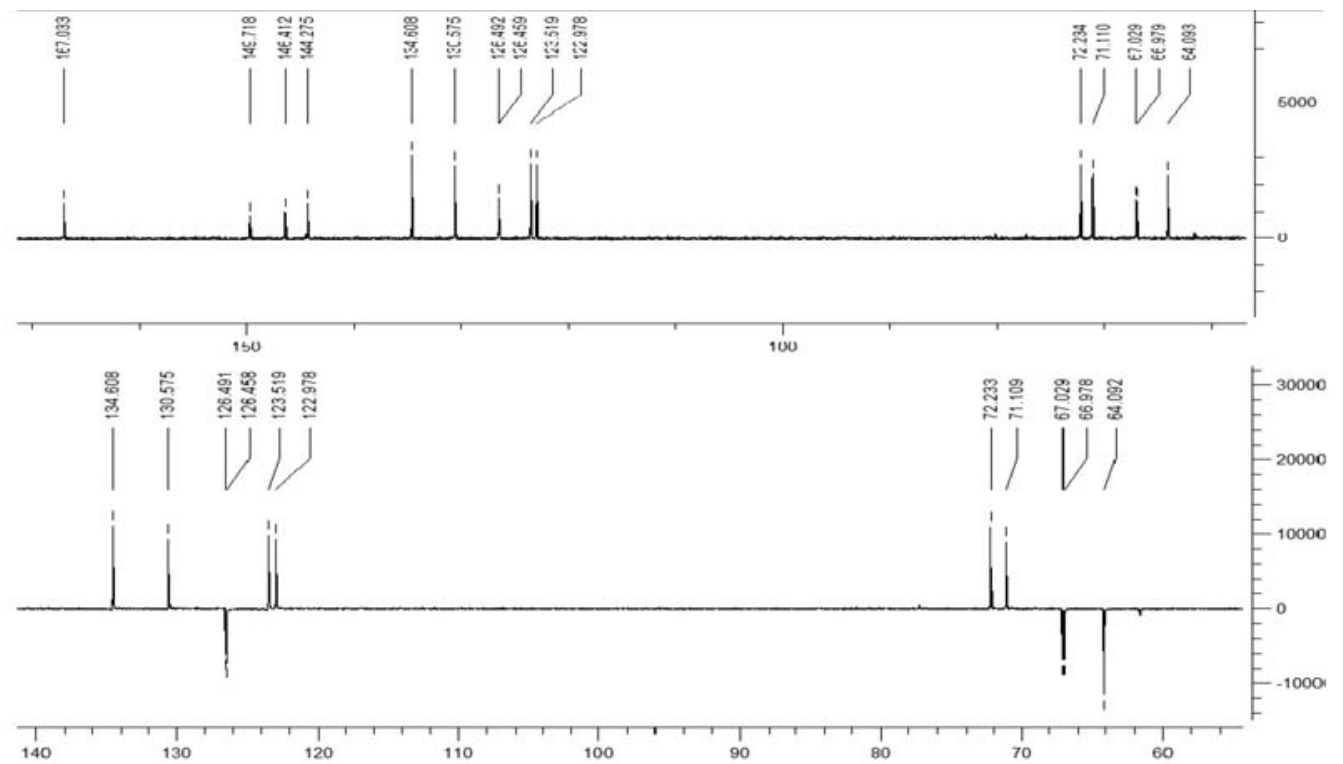

Figure S44. ${ }^{13} \mathrm{C}$ NMR spectrum of compound 9.

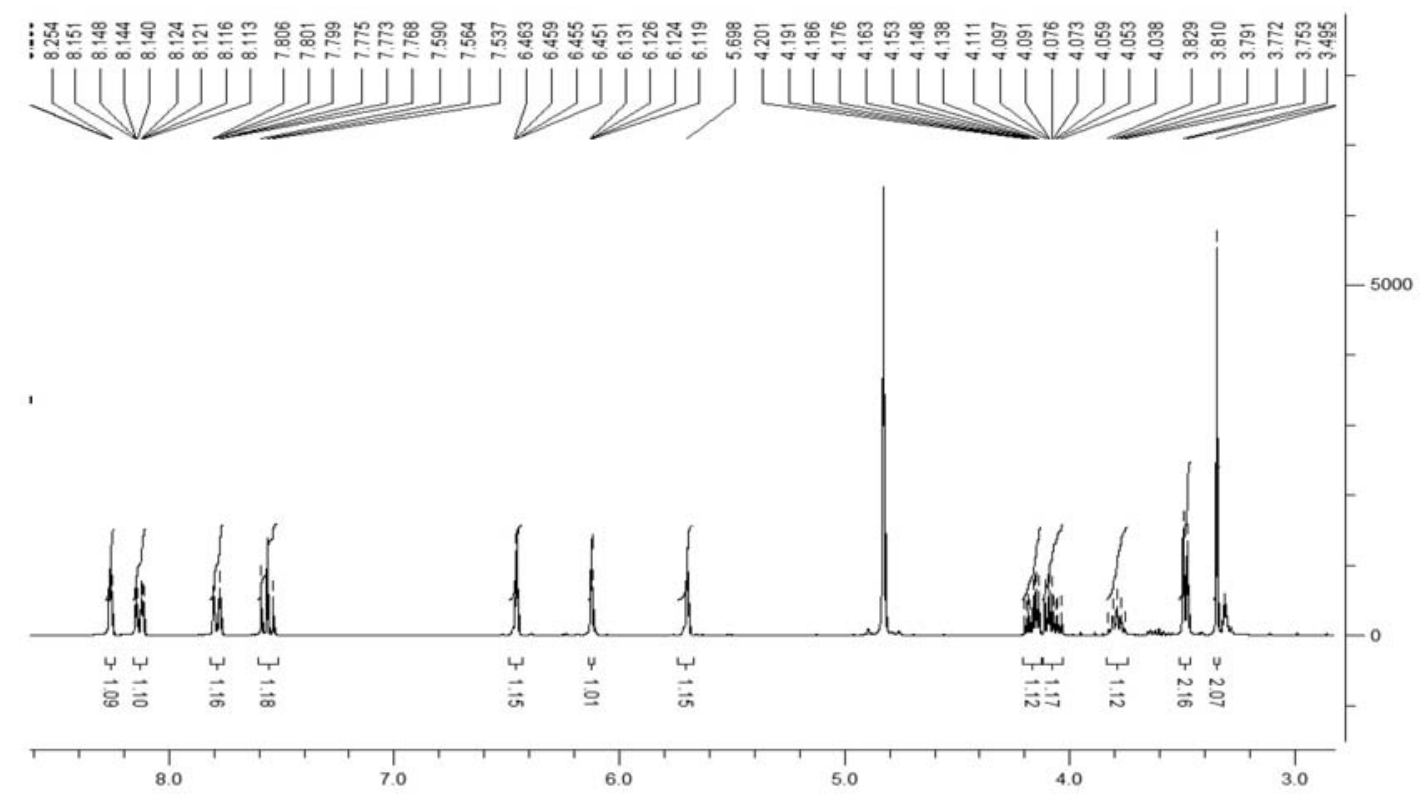

Figure S45. ${ }^{1} \mathrm{H}$ NMR spectrum of compound 9. 


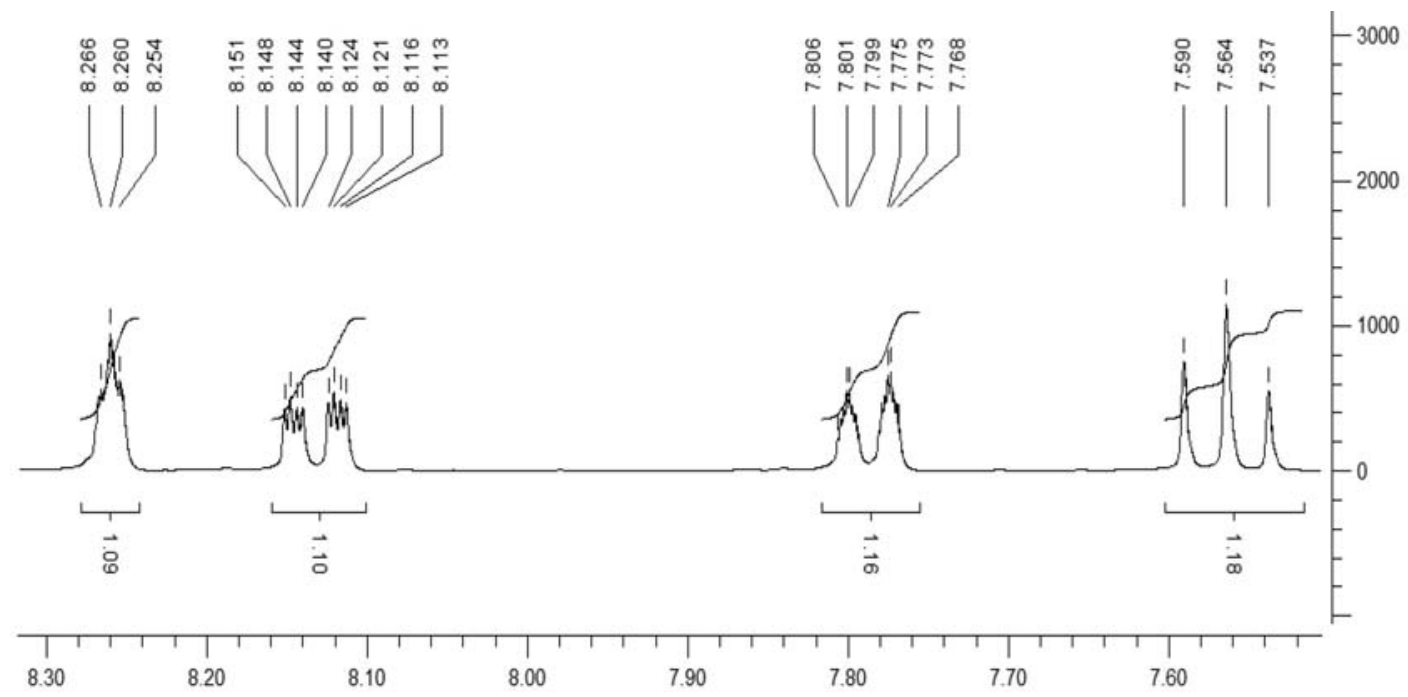

Figure S46. ${ }^{1} \mathrm{H}$ NMR spectrum of compound 9.

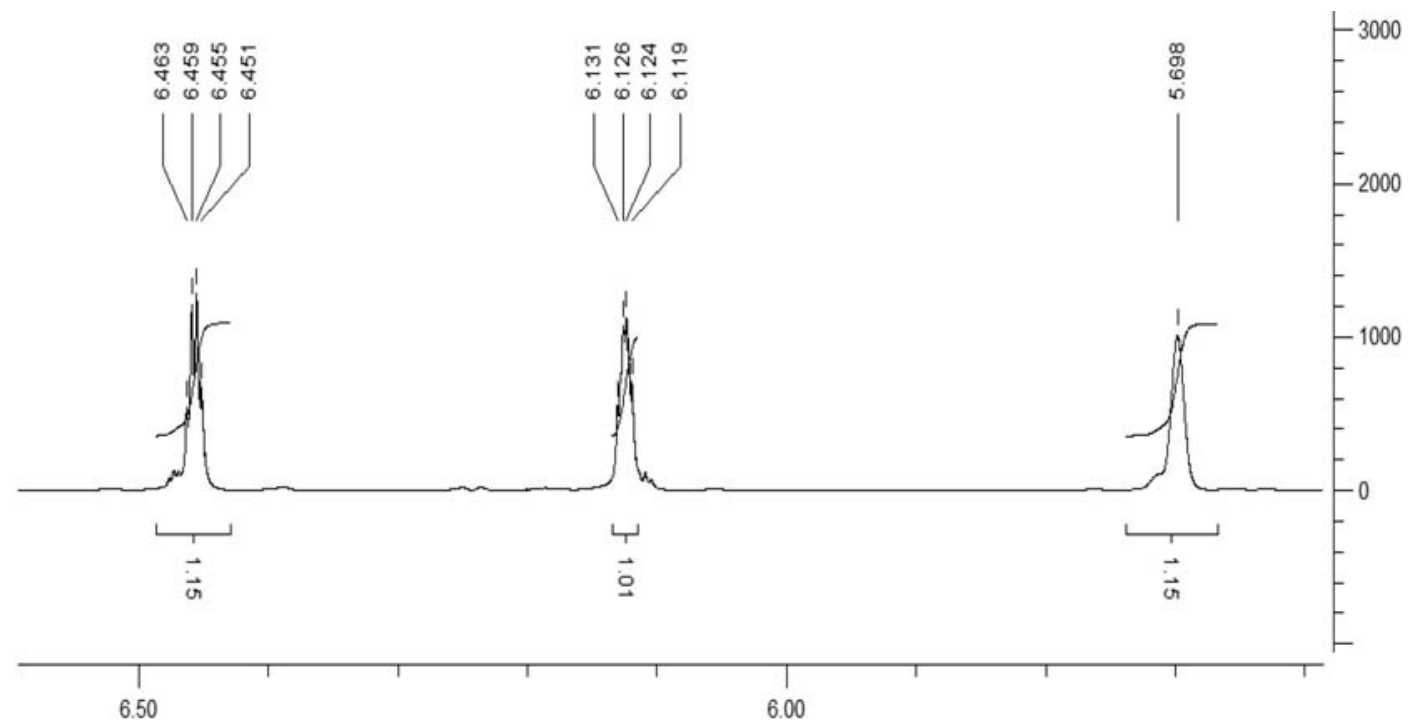

Figure S47. ${ }^{1} \mathrm{H}$ NMR spectrum of compound 9. 


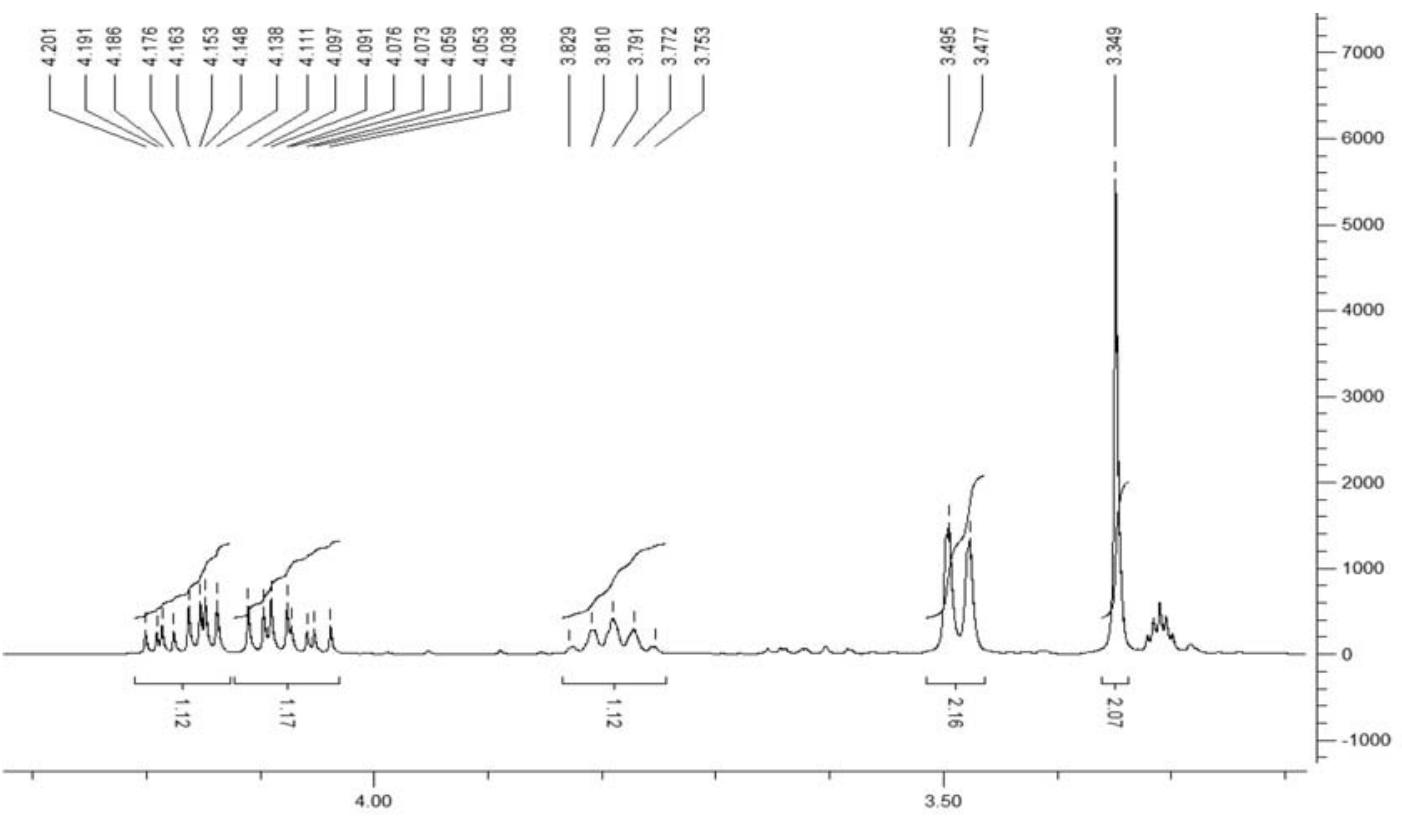

Figure S48. ${ }^{1} \mathrm{H}$ NMR spectrum of compound 9.

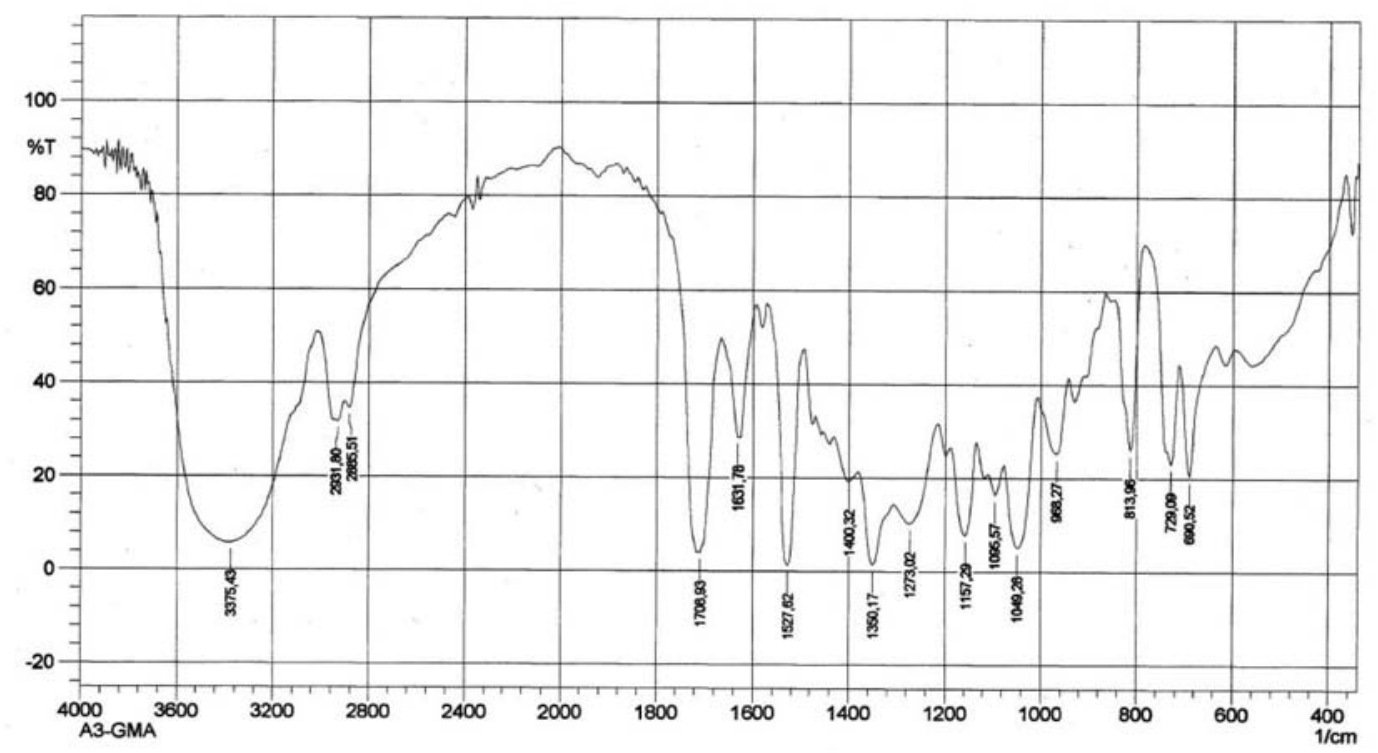

Figure S49. IR spectrum of compound 9 . 


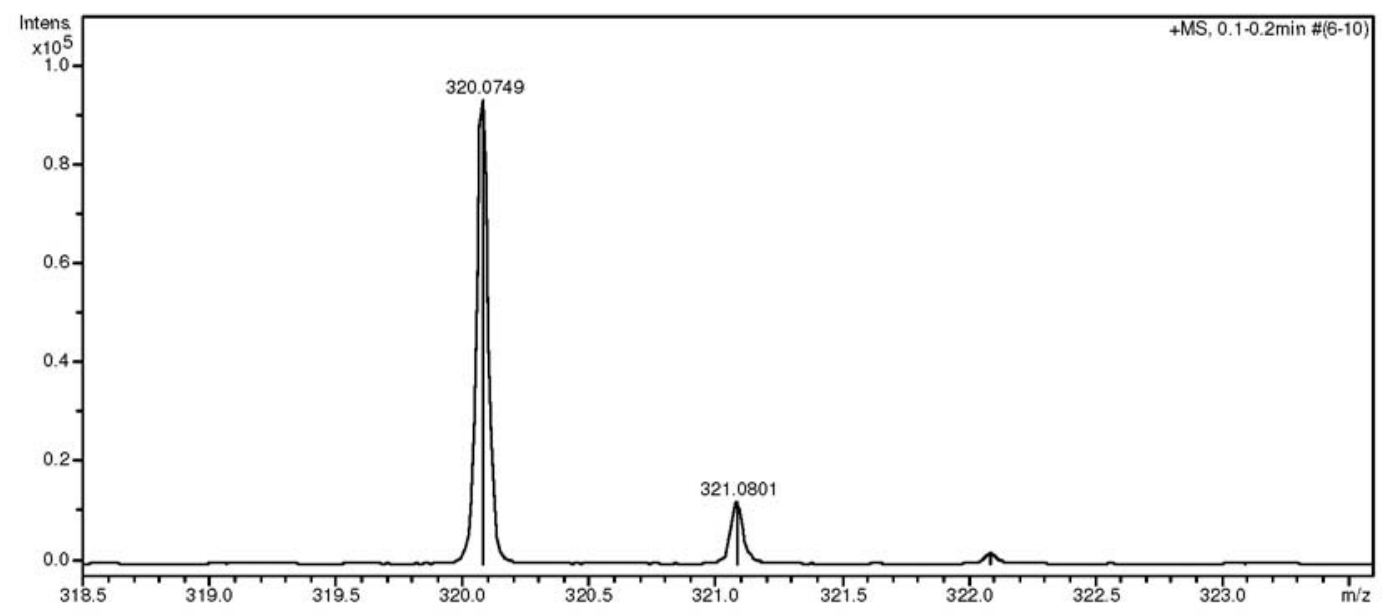

Figure S50. ESI-HRMS spectrum of compound 9.

\section{2,3-Dihydroxypropyl[2-(hydroxyl(4-nitrophenyl)methyl)] acrylate (10)}<smiles>O=C(OCC(O)CO)C(=O)C(O)c1ccc([N+](=O)[O-])cc1</smiles>

${ }^{1} \mathrm{H}$ NMR (MeOD, $\left.300 \mathrm{MHz}\right): \delta 3.35(\mathrm{~s}, 2 \mathrm{H}), 3.47-3.51(\mathrm{~m}, 3 \mathrm{H}), 3.75-3.82(\mathrm{~m}, 1 \mathrm{H}), 4.04-4.21(\mathrm{~m}, 2 \mathrm{H}), 5.69(\mathrm{~s}, 1 \mathrm{H})$, $6.10(\mathrm{dd}, 1 \mathrm{H}, J 2.1 / 1.5 \mathrm{~Hz}), 6.44(\mathrm{dd}, 1 \mathrm{H}, J 2.1 / 0.9 \mathrm{~Hz}), 7.63(\mathrm{~d}, 2 \mathrm{H}, J 9.0 \mathrm{~Hz}), 8.19(\mathrm{~d}, 2 \mathrm{H}, J 9.0 \mathrm{~Hz}) ;{ }^{13} \mathrm{C} \mathrm{NMR}(\mathrm{MeOH}$, $75 \mathrm{MHz}): \delta$ 64.1, 67.0, 71.1, 72.3, 124.5, 126.6, 129.3, 138.4, 144.2, 148.9, 167.0; IR (KBr) $v_{\max } / \mathrm{cm}^{-1}: 3375,1708,1519$, 1350, 1269, 1157, 1111, 1049; ESI-HRMS $(\mathrm{m} / \mathrm{z})$ calc. for $\mathrm{C}_{13} \mathrm{H}_{15} \mathrm{NO}_{7}\left[(\mathrm{M}+\mathrm{Na})^{+}\right] 320.0746$, found 320.0749 .

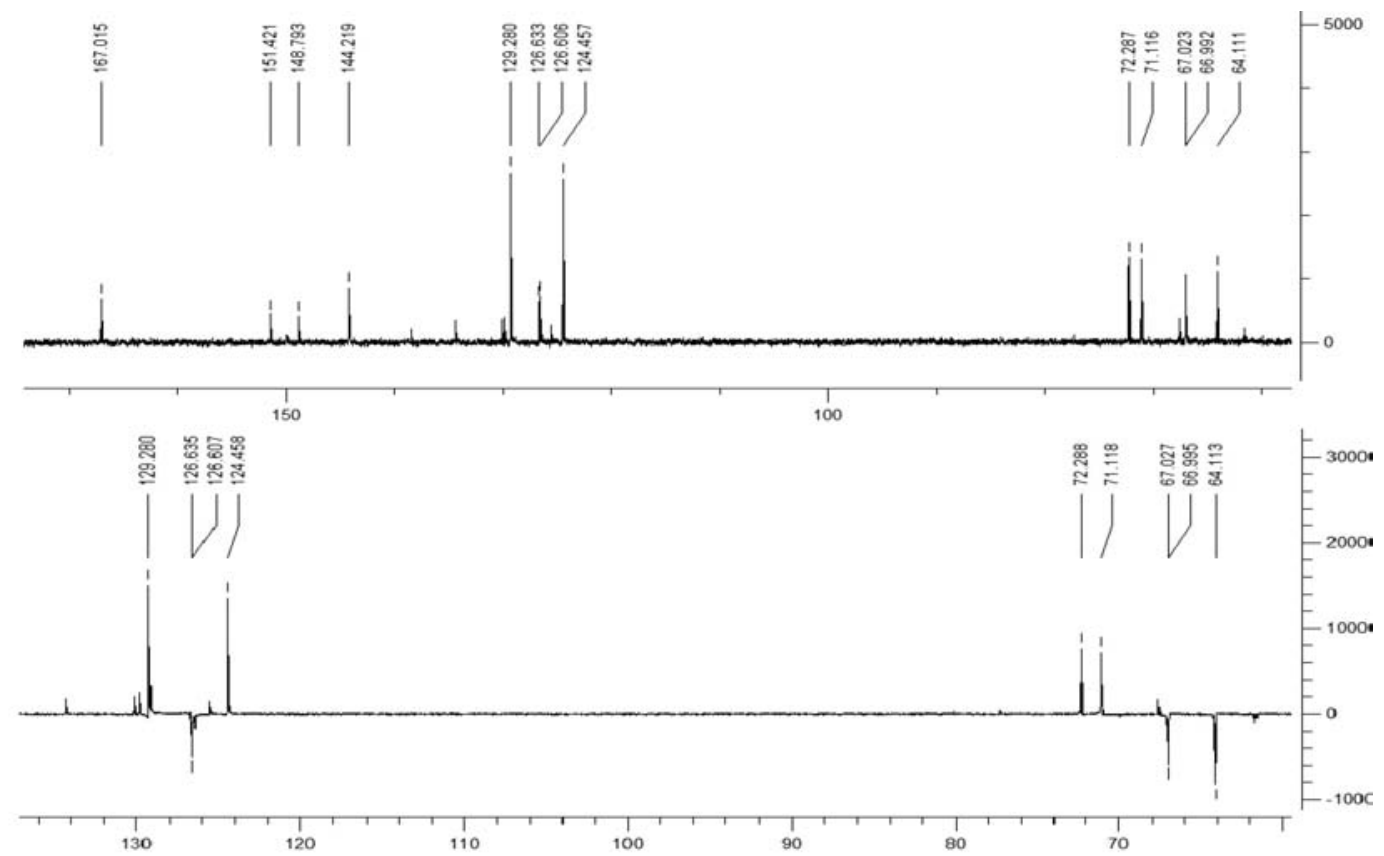

Figure S51. ${ }^{13} \mathrm{C}$ NMR spectrum of compound $\mathbf{1 0}$. 


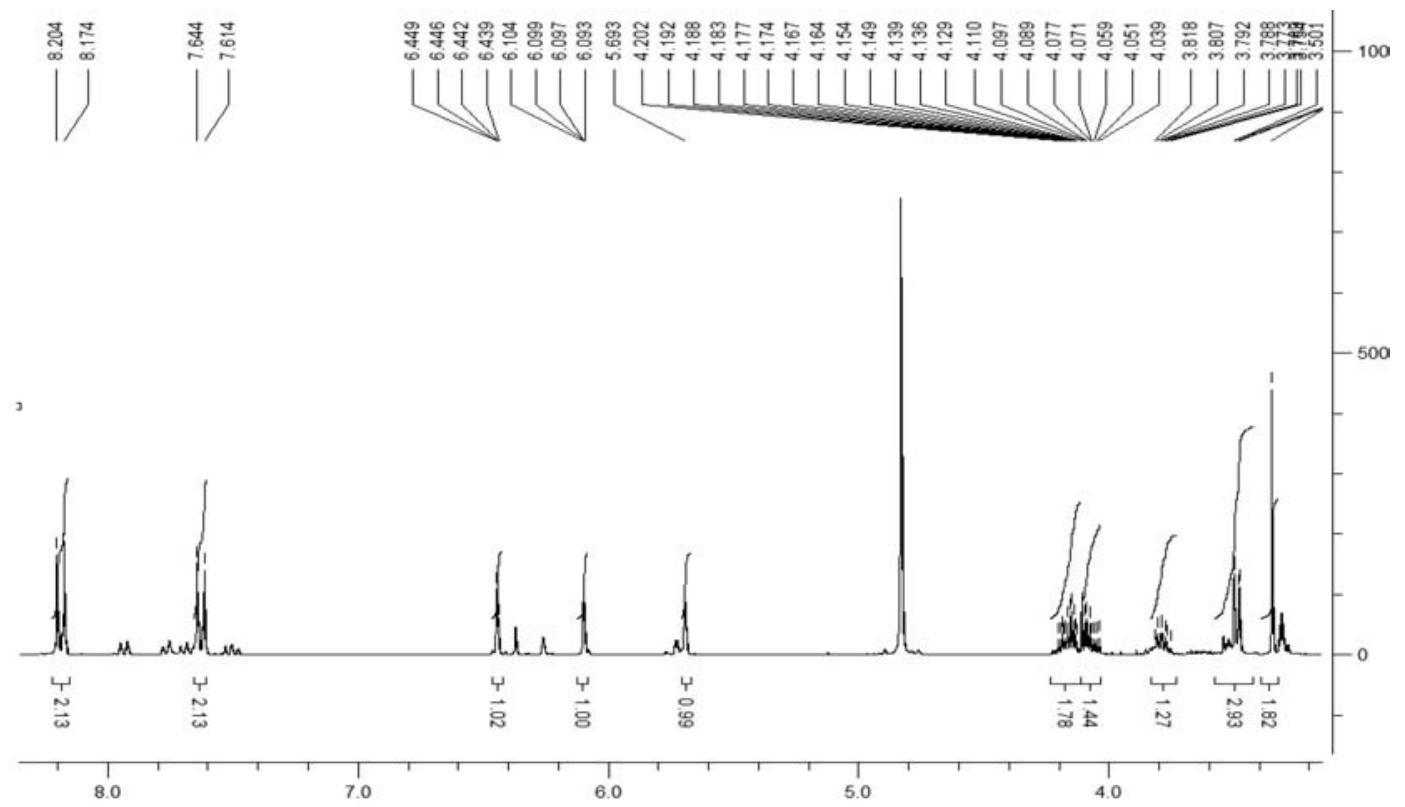

Figure S52. ${ }^{1} \mathrm{H}$ NMR spectrum of compound $\mathbf{1 0}$.

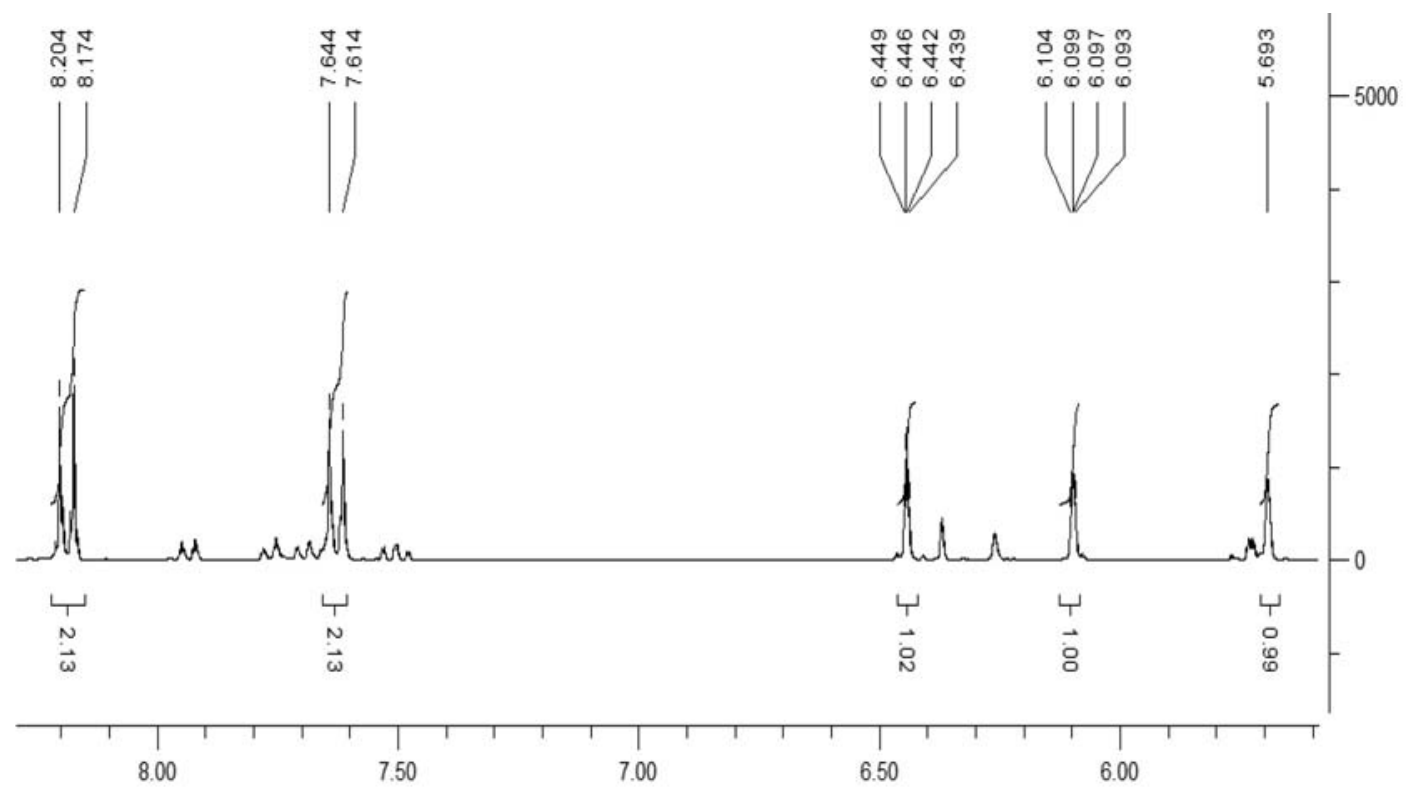

Figure S53. ${ }^{1} \mathrm{H}$ NMR spectrum of compound $\mathbf{1 0}$. 


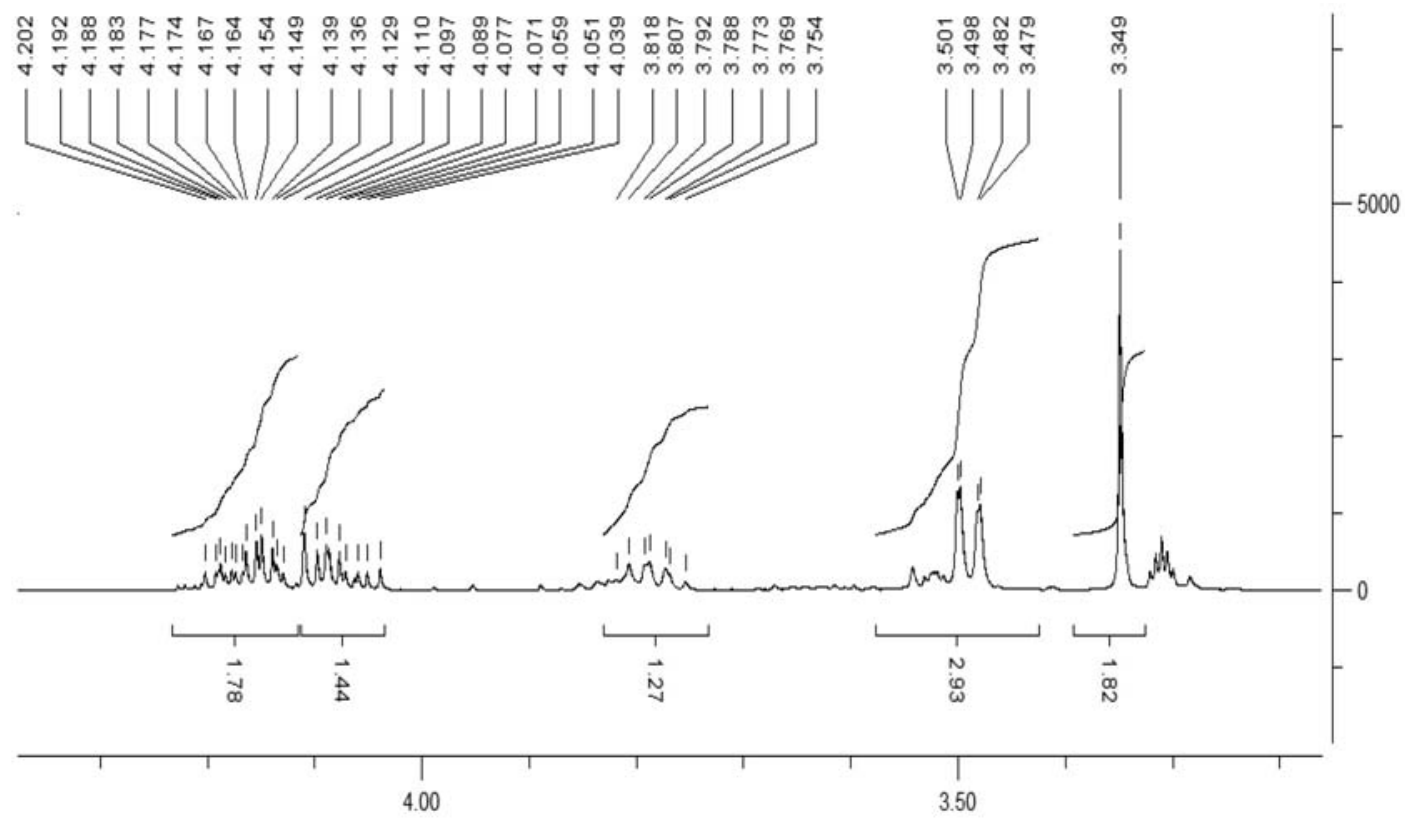

Figure S54. ${ }^{1} \mathrm{H}$ NMR spectrum of compound $\mathbf{1 0}$.

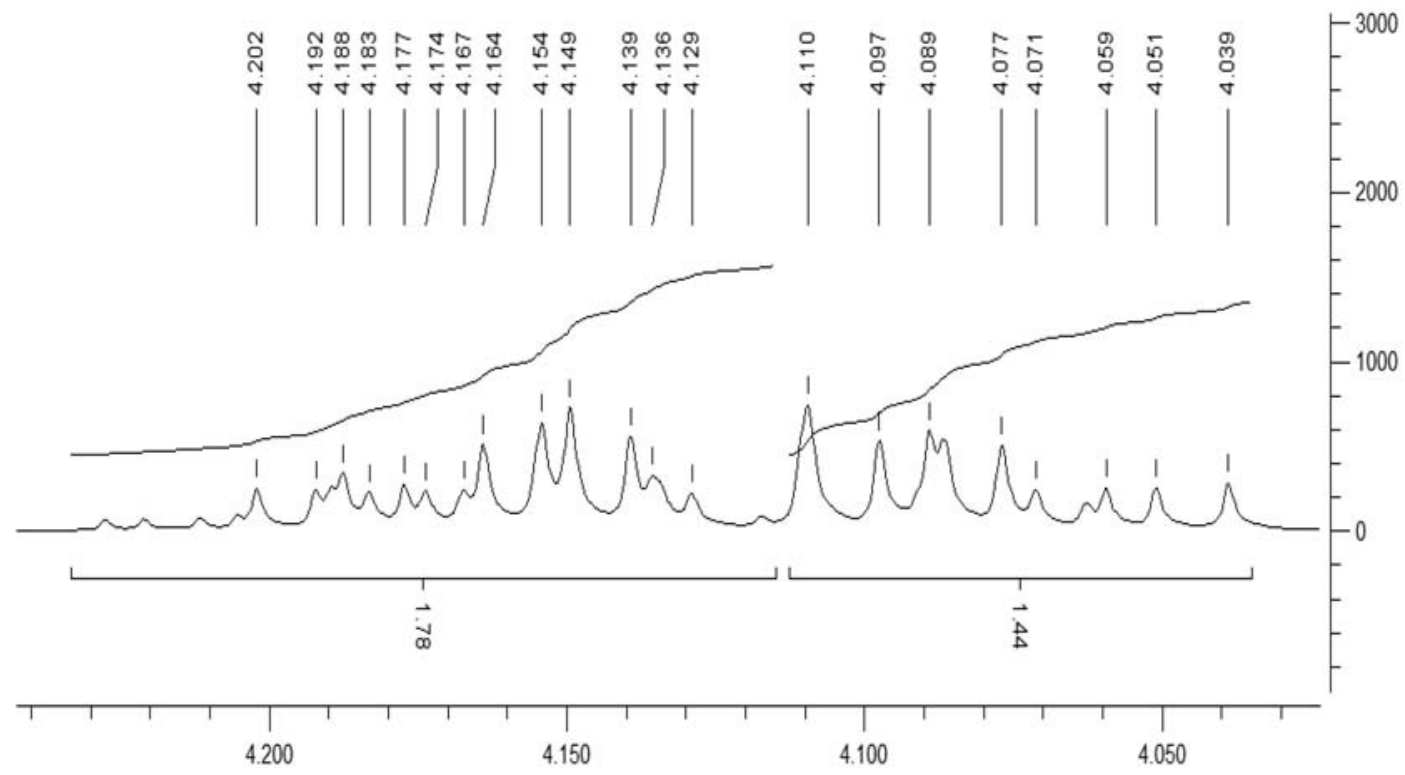

Figure S55. ${ }^{1} \mathrm{H}$ NMR spectrum of compound $\mathbf{1 0}$. 


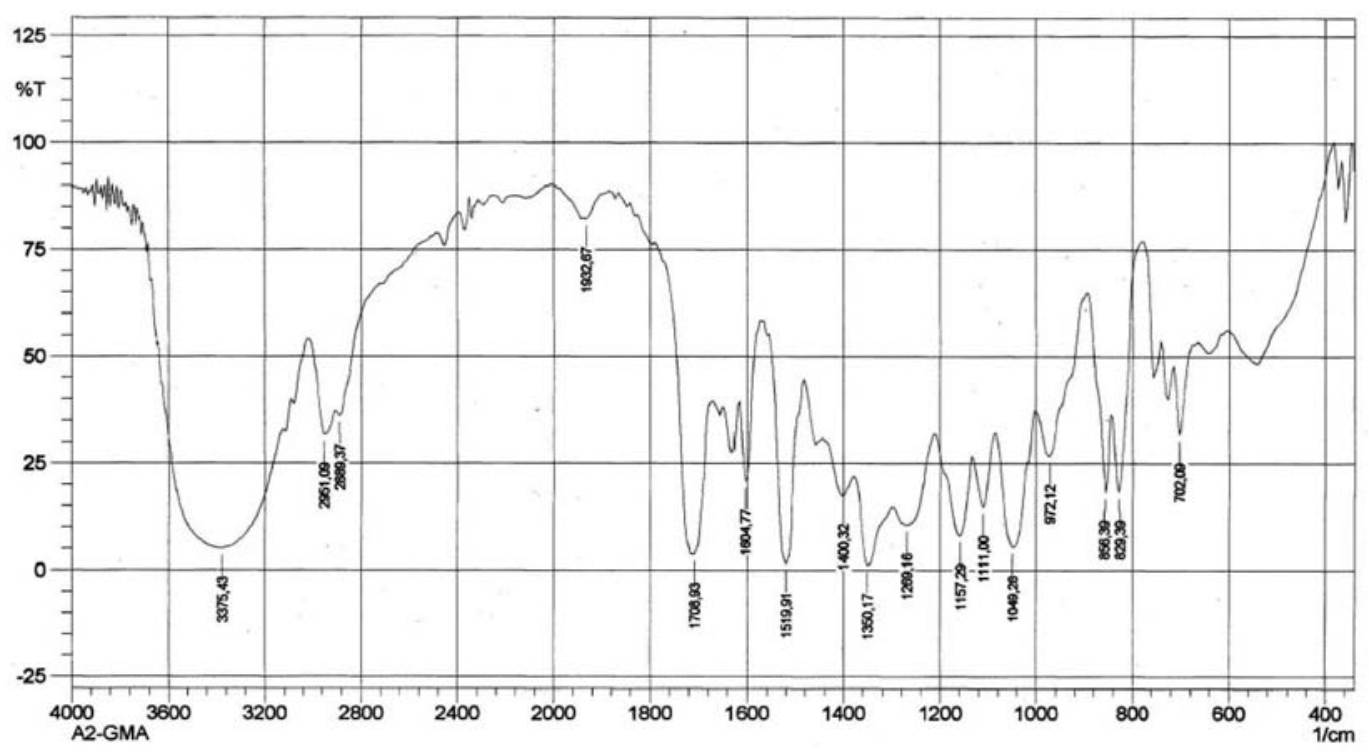

Figure S56. IR spectrum of compound 10.

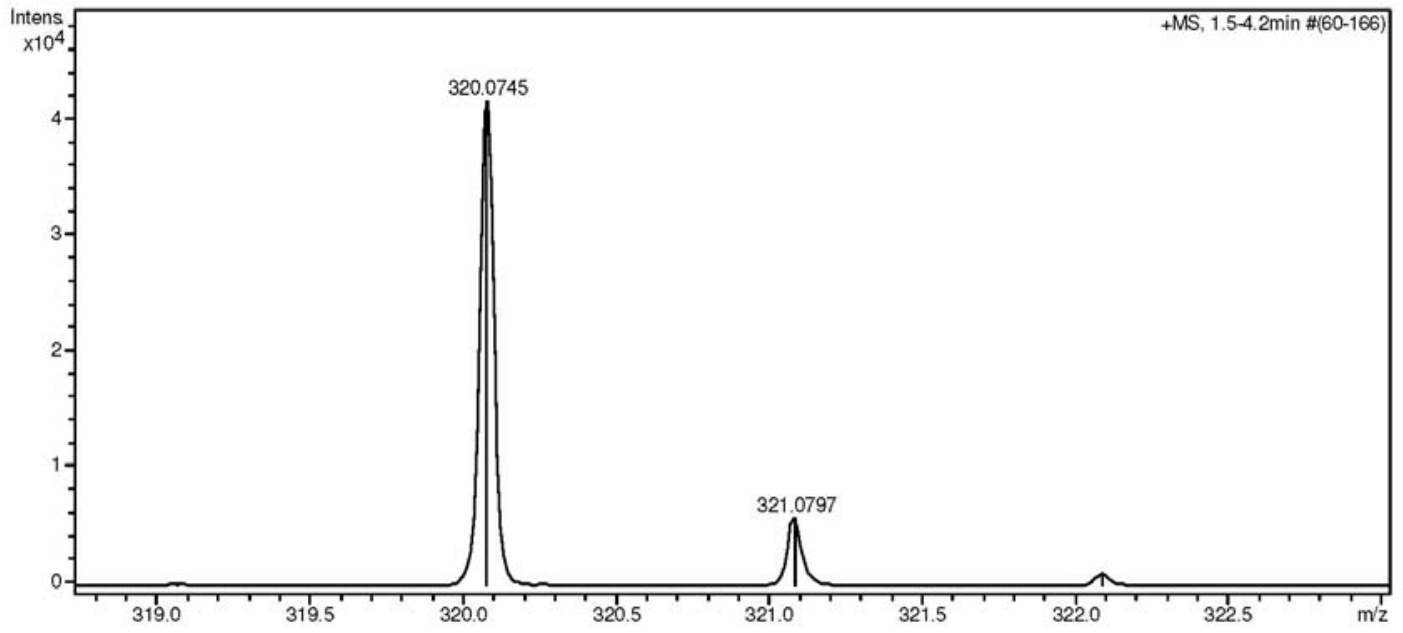

Figure S57. ESI-HRMS spectrum of compound $\mathbf{1 0}$. 
2,3-Dihydroxypropyl[2-(hydroxy(pyridin-2-yl)methyl)] acrylate (11)<smiles>C=C(C(=O)OCC(O)CO)C(O)c1ccccn1</smiles>

${ }^{1} \mathrm{H}$ NMR (MeOD, $300 \mathrm{MHz}$ ): $\delta 3.349$ (s, 2H), 3.470-3.670 (m, 3H), 3.750-3.825 (m, 1H), 4.08 (ddd, $\left.1 \mathrm{H}, J 11.4 / 9.0 / 6.0 \mathrm{~Hz}\right)$, $4.17(\mathrm{ddd}, 1 \mathrm{H}, J 11.4 / 7.5 / 4.5 \mathrm{~Hz}), 5.66(\mathrm{~s}, 1 \mathrm{H}), 5.98(\mathrm{~d}, 1 \mathrm{H}, J 0.6 \mathrm{~Hz}), 6.43(\mathrm{~d}, 1 \mathrm{H}, J 0.9 \mathrm{~Hz}), 7.31(\mathrm{ddd}, 1 \mathrm{H}, J 7.5 / 5.1 / 1.2 \mathrm{~Hz})$, 7.56 (d, $1 \mathrm{H}, J 8.1 \mathrm{~Hz}), 7.82$ (td, $1 \mathrm{H}, J 7.8 / 1.8 \mathrm{~Hz}), 8.46$ (ddd, $1 \mathrm{H}, J 5.1 / 1.8 / 0.9 \mathrm{~Hz}) ;{ }^{13} \mathrm{C} \mathrm{NMR}(\mathrm{MeOH}, 75 \mathrm{MHz}): \delta 64.1$, $67.0,71.1,73.9,123.2,124.2,127.1,138.8,143.8,149.47,162.5,167.3 ; \mathrm{IR}(\mathrm{KBr}) v_{\max } / \mathrm{cm}^{-1}: 3383,1712,1269,1161,1111$, 1049; ESI-HRMS $(\mathrm{m} / \mathrm{z})$ calc. for $\mathrm{C}_{12} \mathrm{H}_{15} \mathrm{NO}_{5}\left[(\mathrm{M}+\mathrm{H})^{+}\right] 254.0983$, found 254.1021.

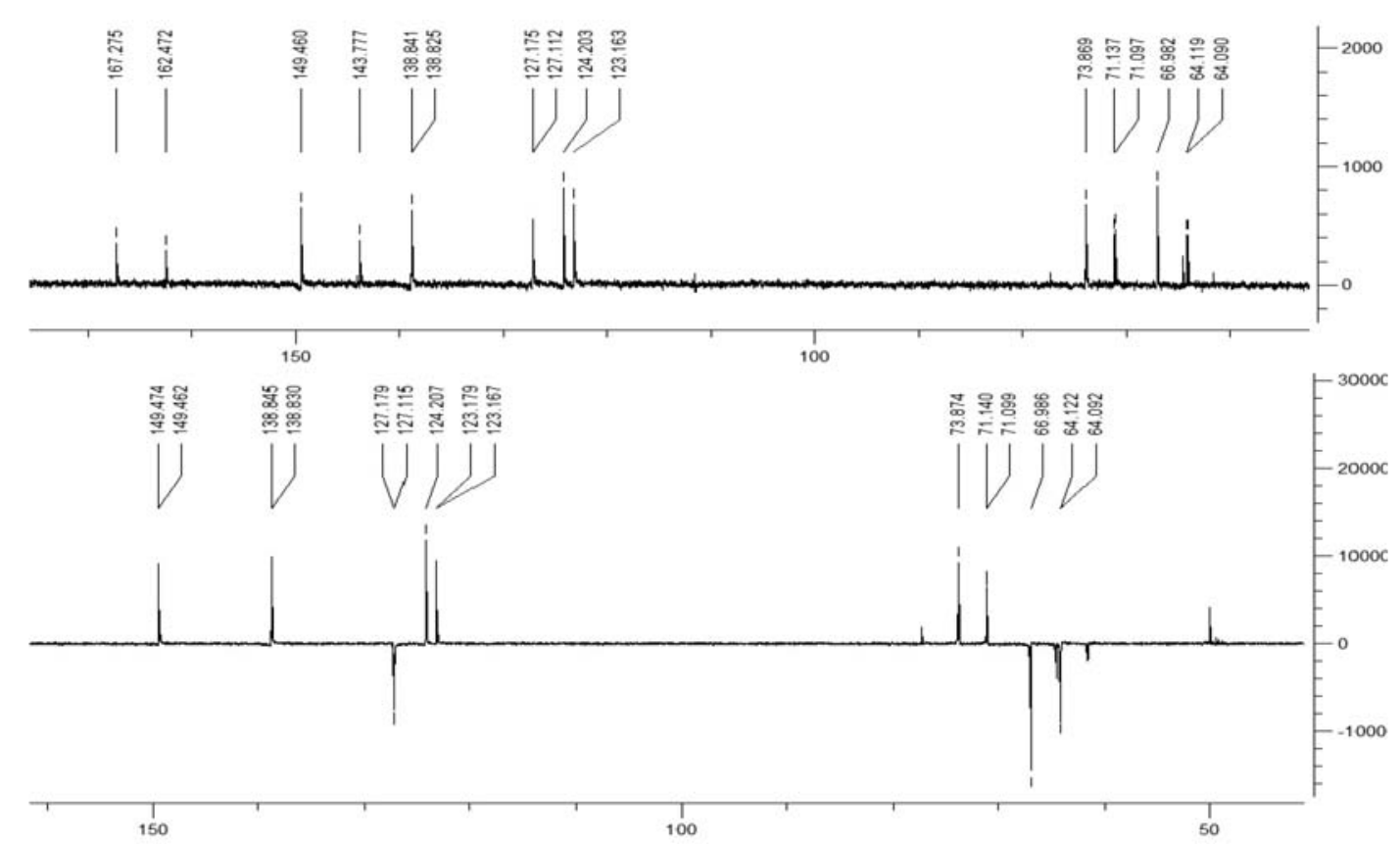

Figure S58. ${ }^{13} \mathrm{C}$ NMR spectrum of compound $\mathbf{1 1}$. 


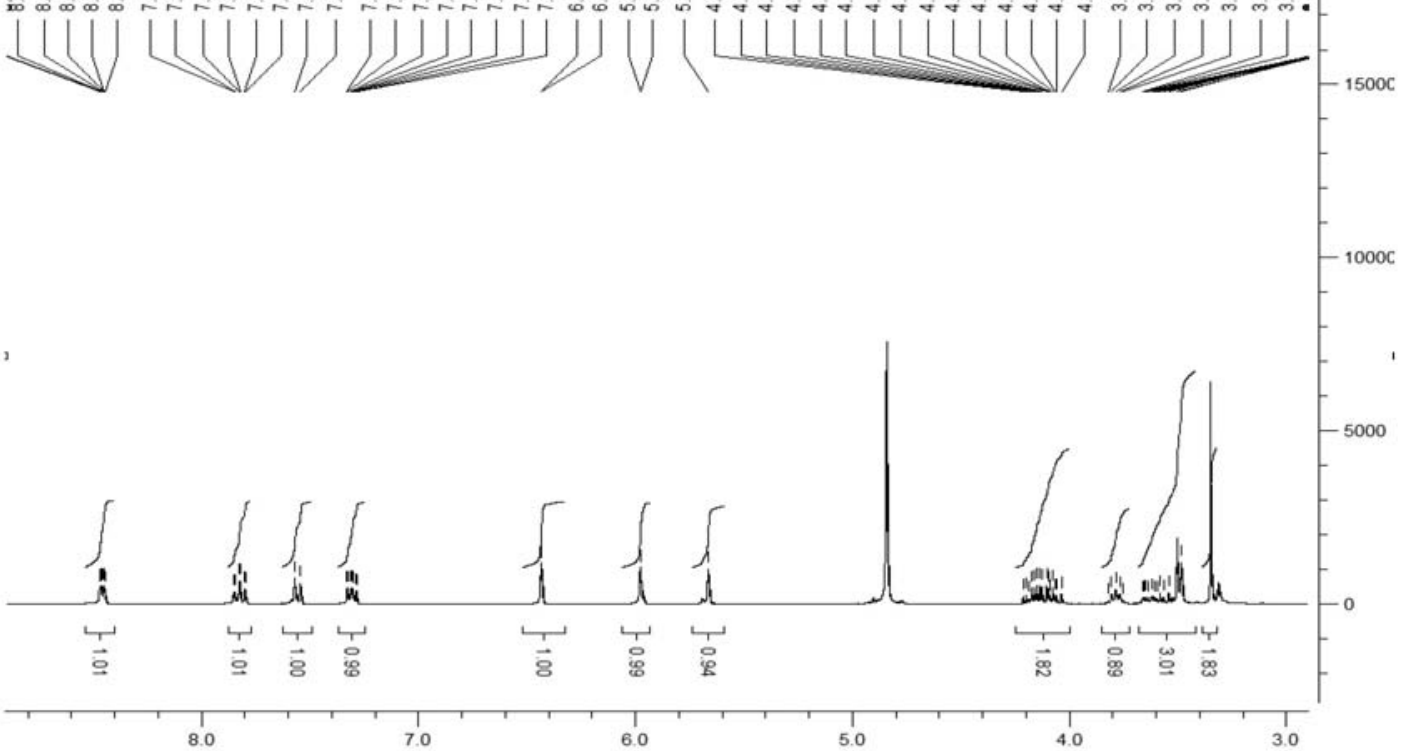

Figure S59. ${ }^{1} \mathrm{H}$ NMR spectrum of compound 11.

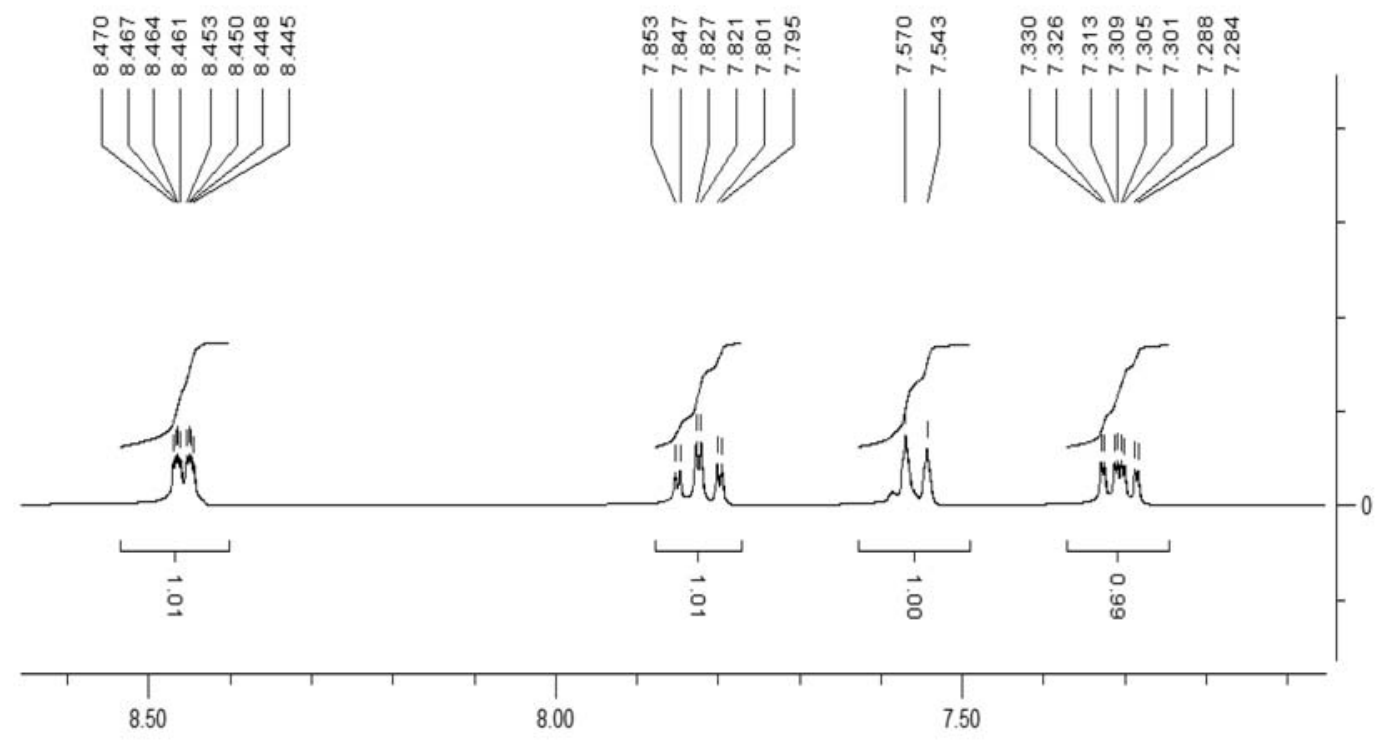

Figure S60. ${ }^{1} \mathrm{H}$ NMR spectrum of compound 11. 


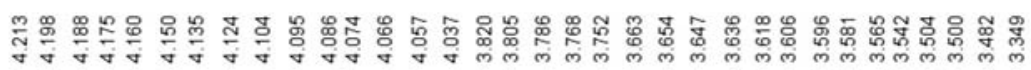
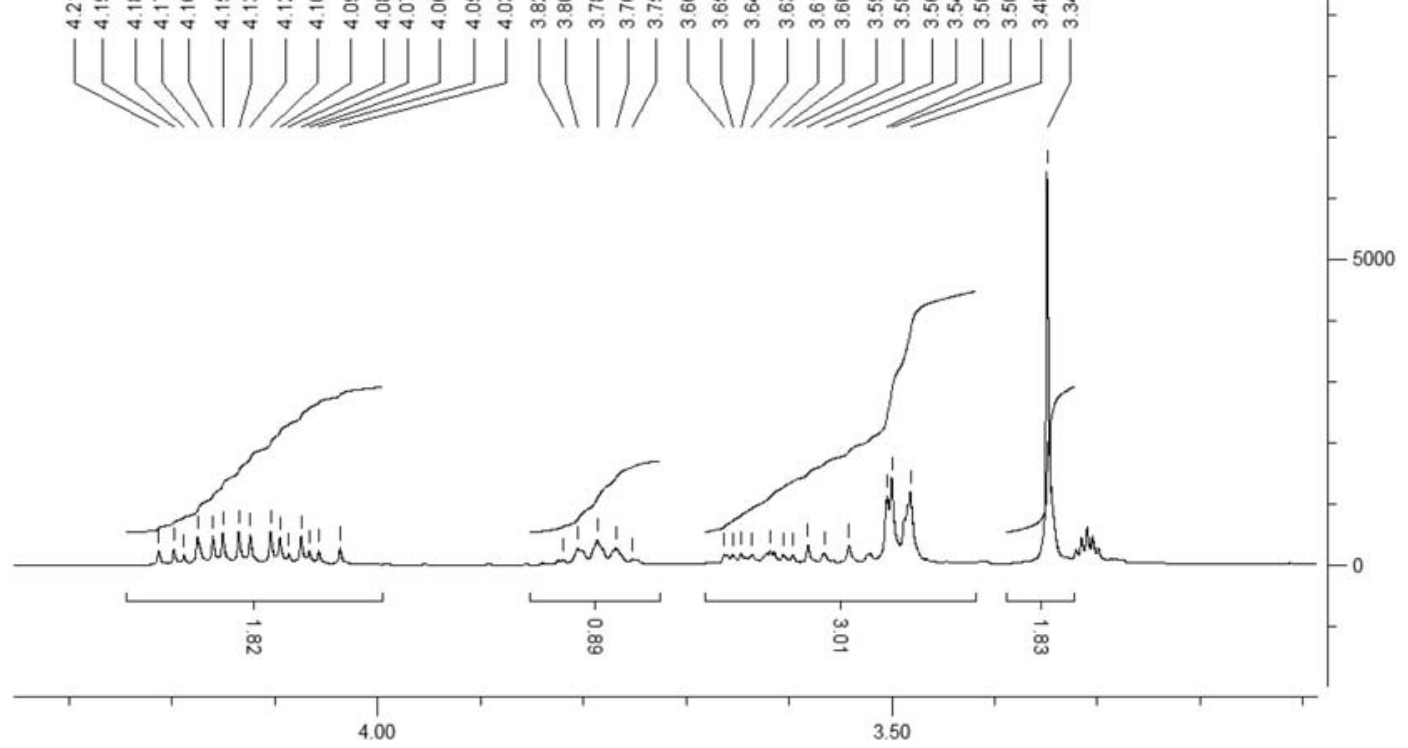

Figure S61. ${ }^{1} \mathrm{H}$ NMR spectrum of compound $\mathbf{1 1 .}$

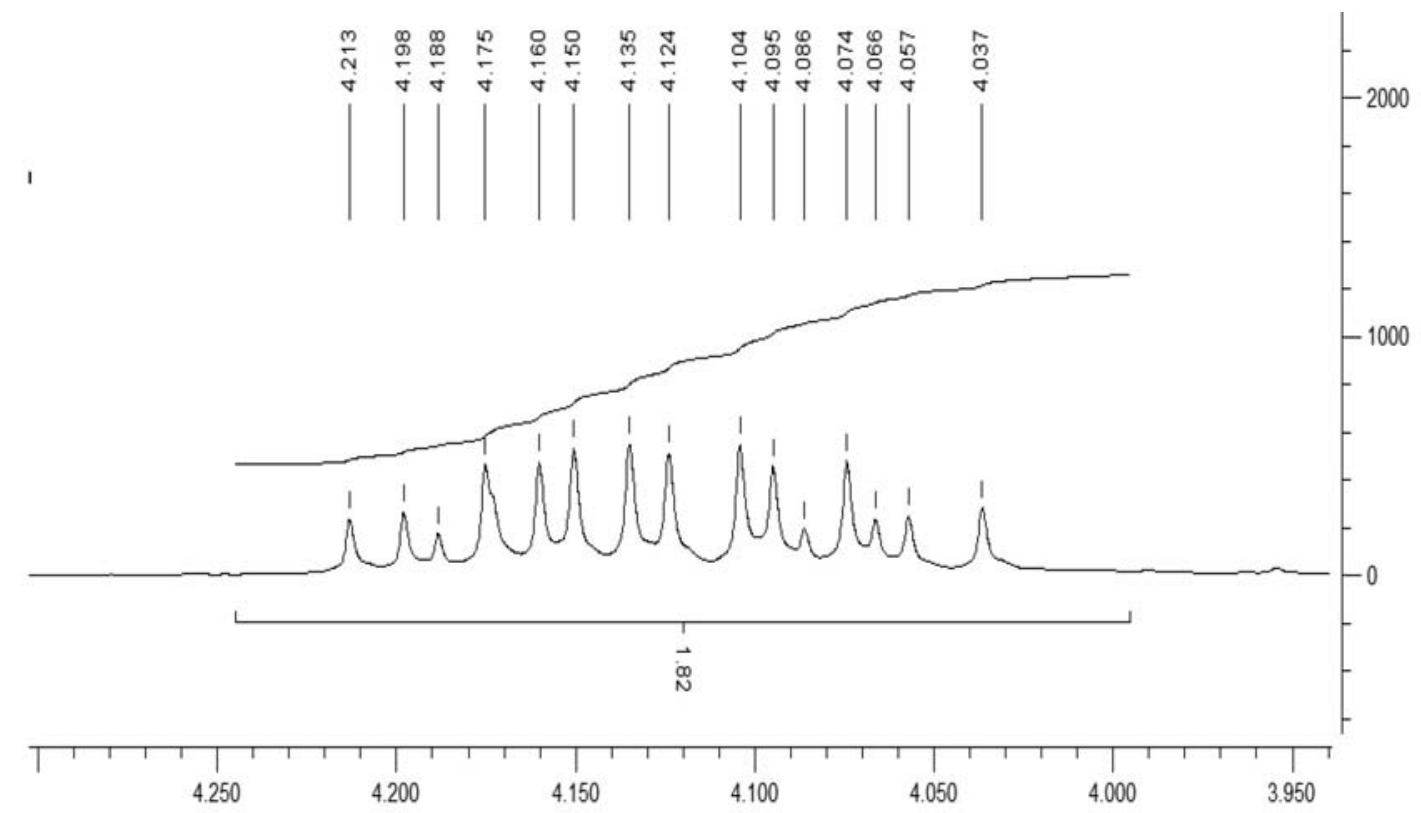

Figure S62. ${ }^{1} \mathrm{H}$ NMR spectrum of compound 11. 


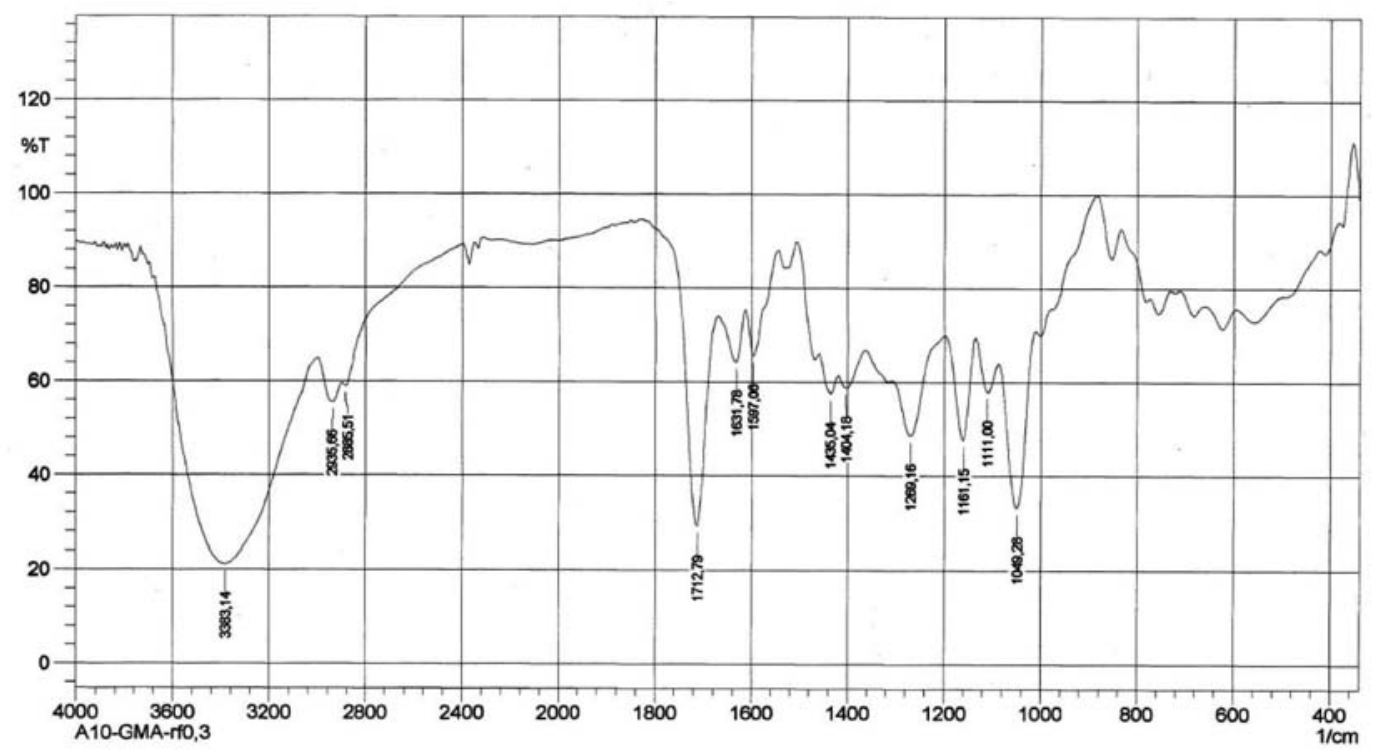

Figure S63. IR spectrum of compound 11.

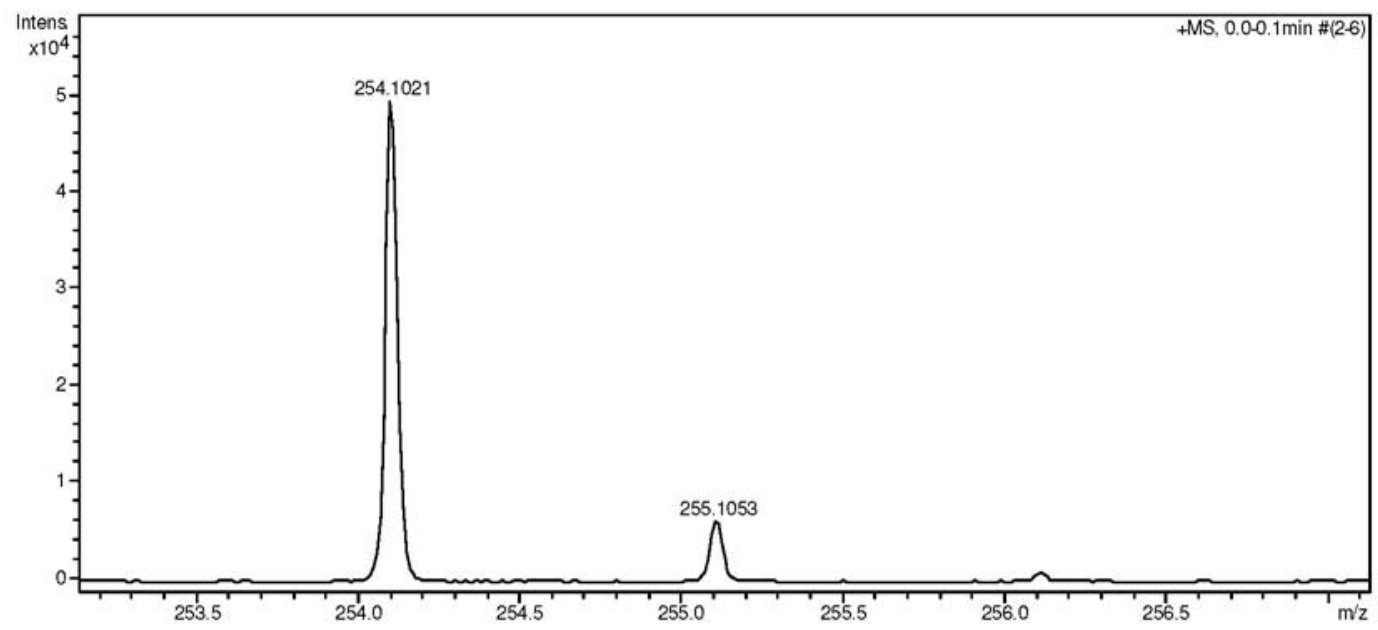

Figure S64. ESI-HRMS spectrum of compound 11. 
2,3-Dihydroxypropyl[2-(hydroxyl(pyridin-3-yl)methyl)] acrylate (12)

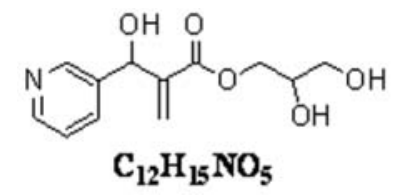

${ }^{1} \mathrm{H}$ NMR (MeOD, $\left.300 \mathrm{MHz}\right): \delta 3.35$ (s, 2H), 3.47-3.67 (m, 3H), 3.75-3.83 (m, 1H), 4.07 (ddd, 1H, J 11.4/6.0/4.2 Hz), 4.17 (ddd, 1H, J 11.4/4.5/2.4 Hz), 5.64 (s, 1H), 6.15 (s, 1H), 6.46 (d, 1H, $J 1.2 \mathrm{~Hz}$ ), 7.40 (ddd, 1H, J 7.8/4.8/0.6 Hz), 7.84 (dt, $1 \mathrm{H}, J$ 8.1/1.8 Hz), 8.43 (dd, 1H, $J 4.8 / 1.5 \mathrm{~Hz}), 8.56$ (d, 1H, $J 1.8 \mathrm{~Hz}) ;{ }^{13} \mathrm{C} \mathrm{NMR}(\mathrm{MeOH}, 75 \mathrm{MHz}): \delta 64.1,67.0,70.9$, 71.1, 125.1, 126.2, 137.0, 140.3, 144.1, 149.2, 149.4, 167.0; IR (KBr) $v_{\max } / \mathrm{cm}^{-1}: 3348,1716,1265,1157,1118,1029$; ESI-HRMS $(m / z)$ calc. for $\mathrm{C}_{12} \mathrm{H}_{15} \mathrm{NO}_{5}\left[(\mathrm{M}+\mathrm{H})^{+}\right] 254.0983$, found 254.1023 .

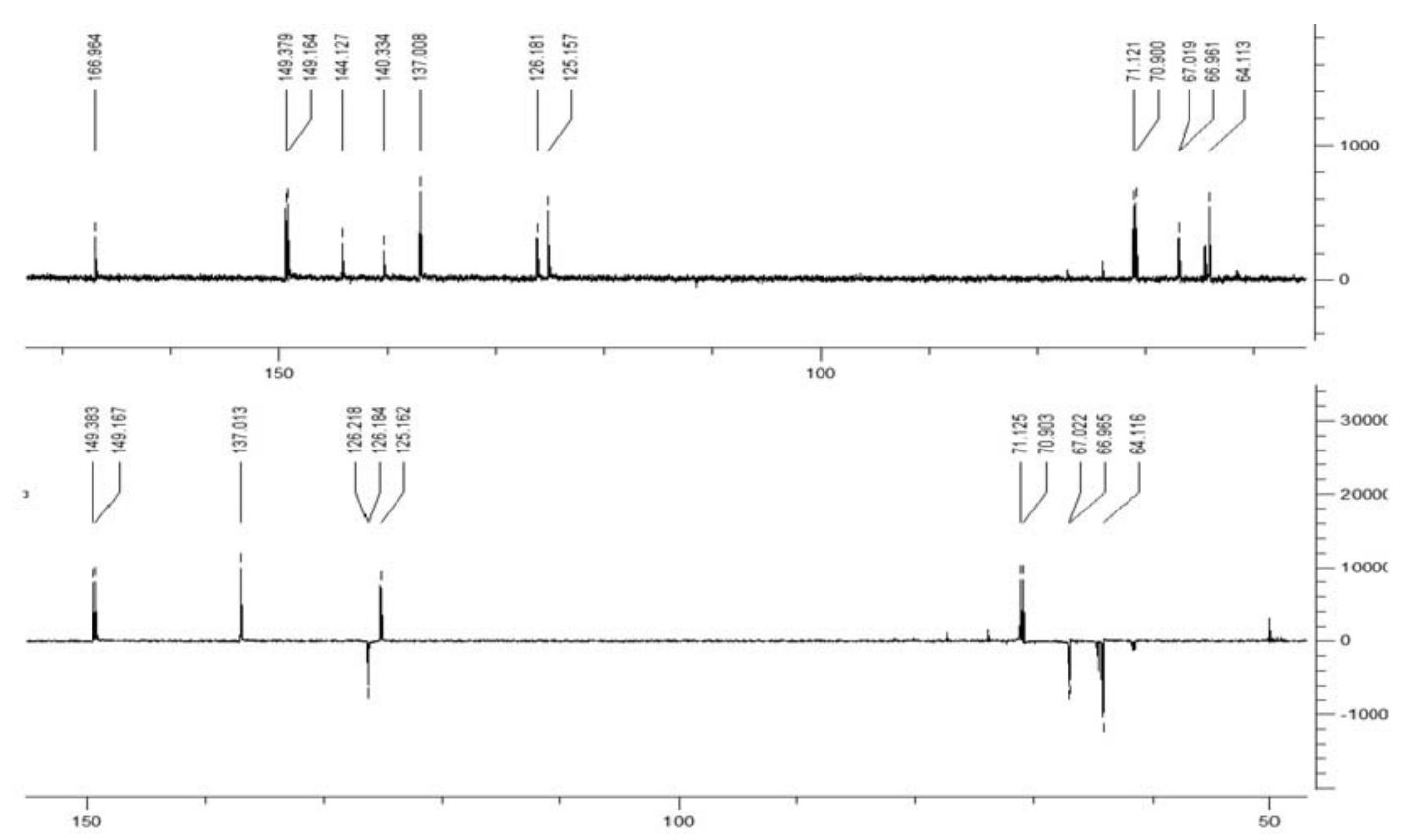

Figure S65. ${ }^{13} \mathrm{C}$ NMR spectrum of compound $\mathbf{1 2}$. 


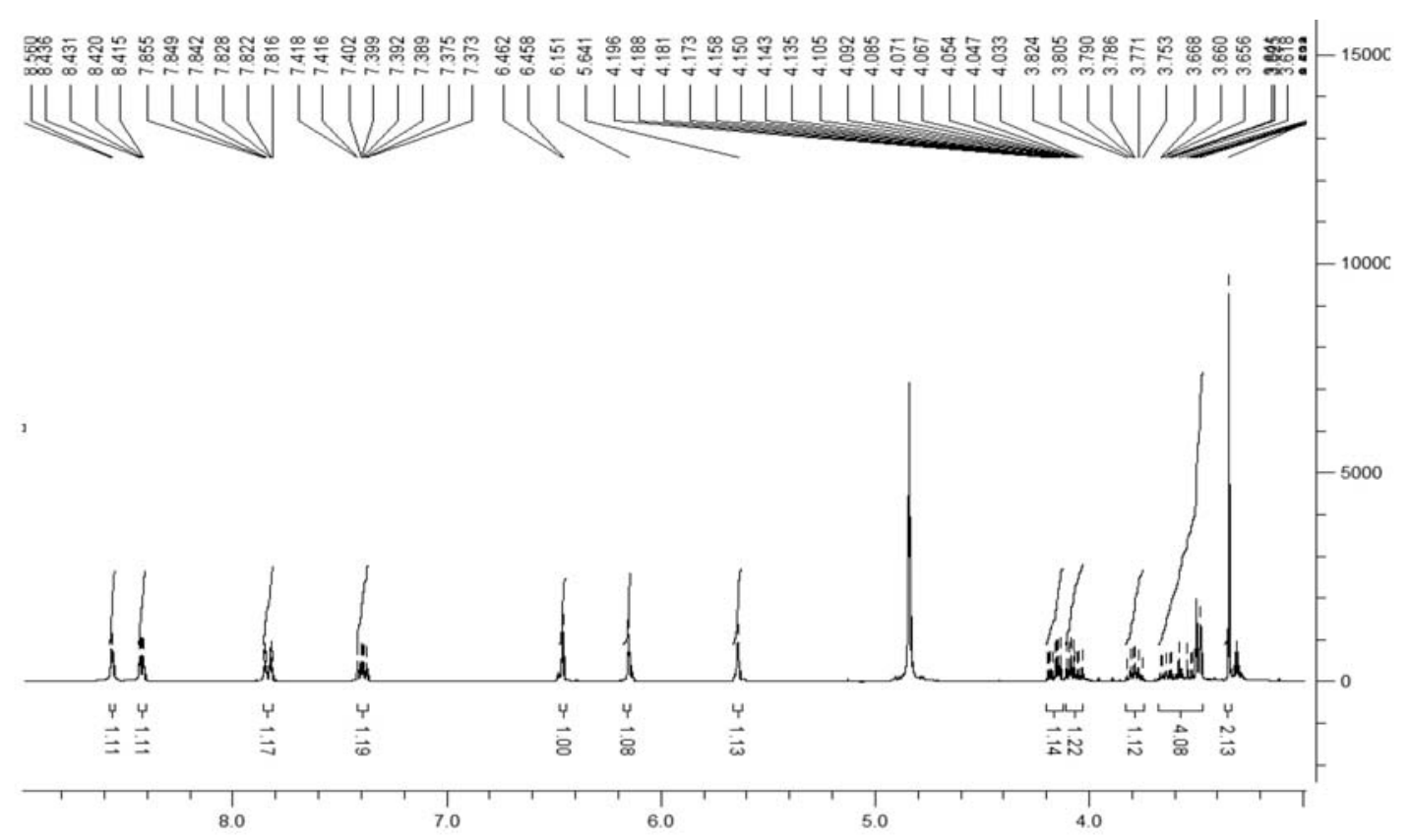

Figure S66. 'H NMR spectrum of compound 12.

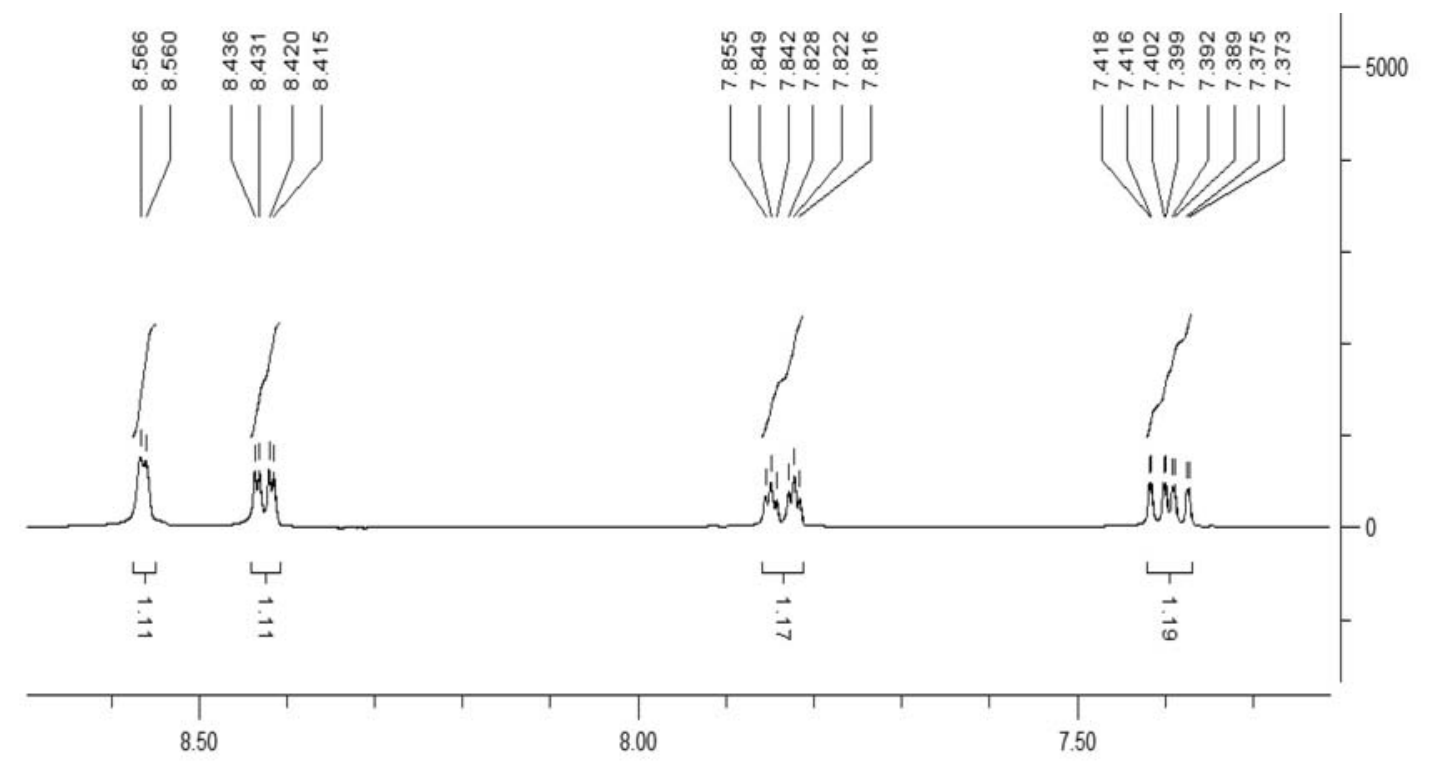

Figure S67. ${ }^{1} \mathrm{H}$ NMR spectrum of compound 12. 


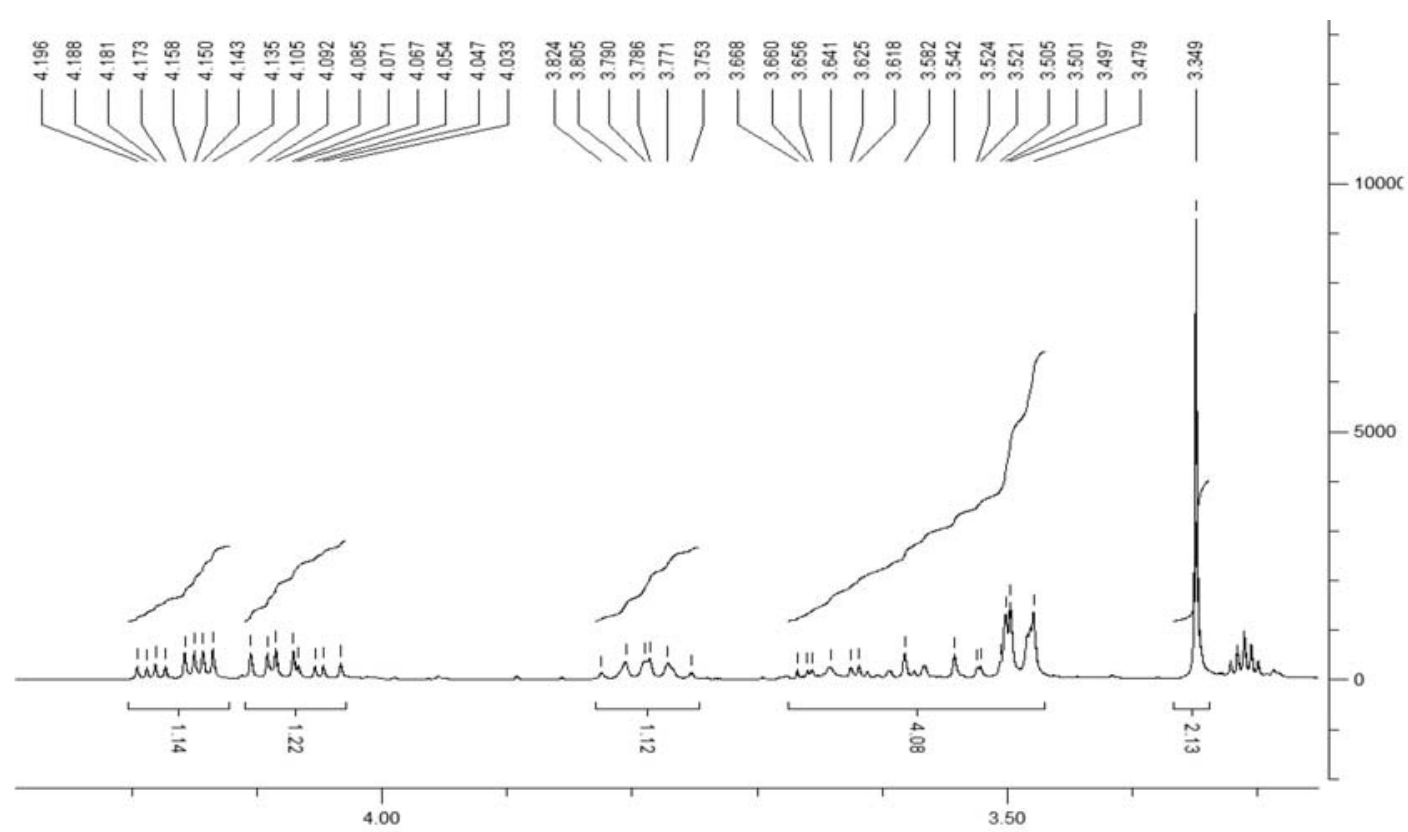

Figure S68. ${ }^{1} \mathrm{H}$ NMR spectrum of compound 12.

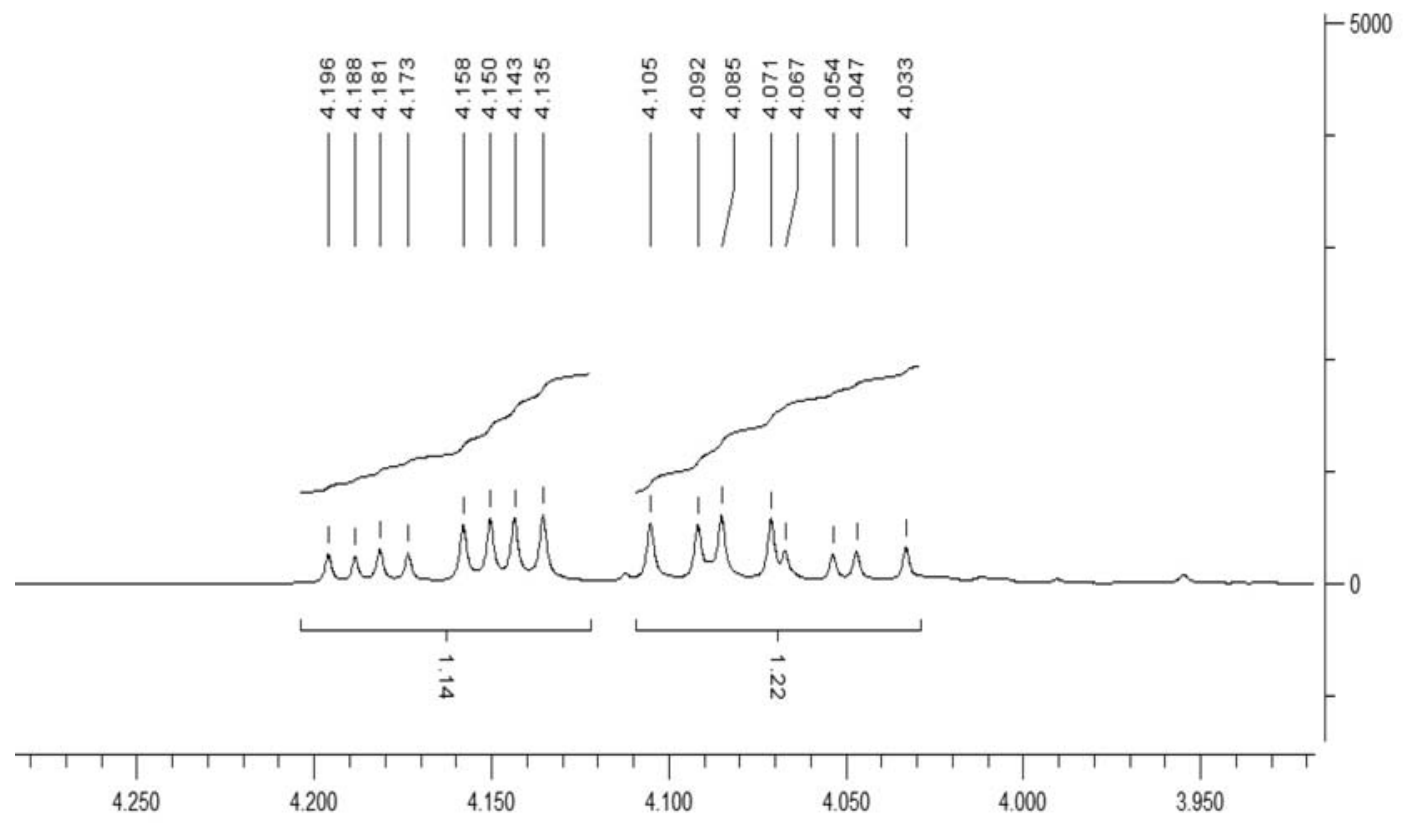

Figure S69. ${ }^{1} \mathrm{H}$ NMR spectrum of compound $\mathbf{1 2}$. 


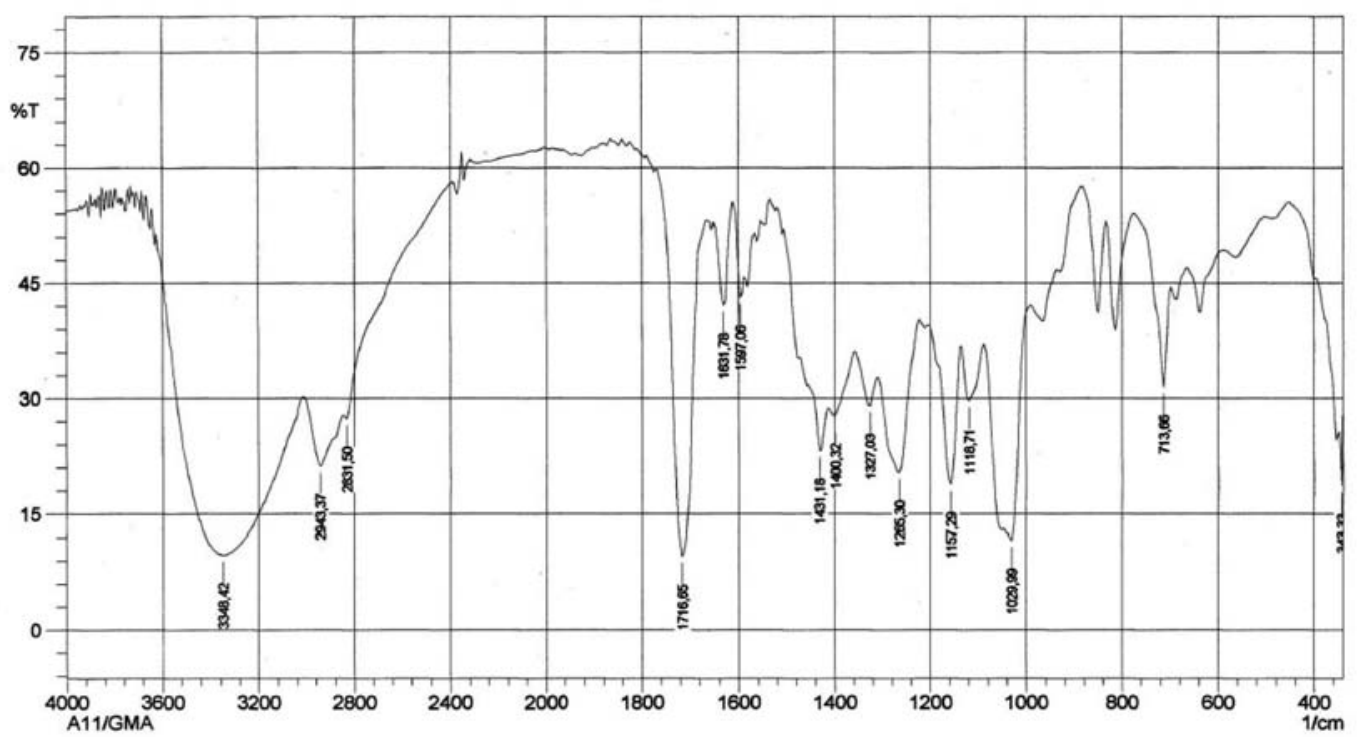

Figure S70. IR spectrum of compound 12.

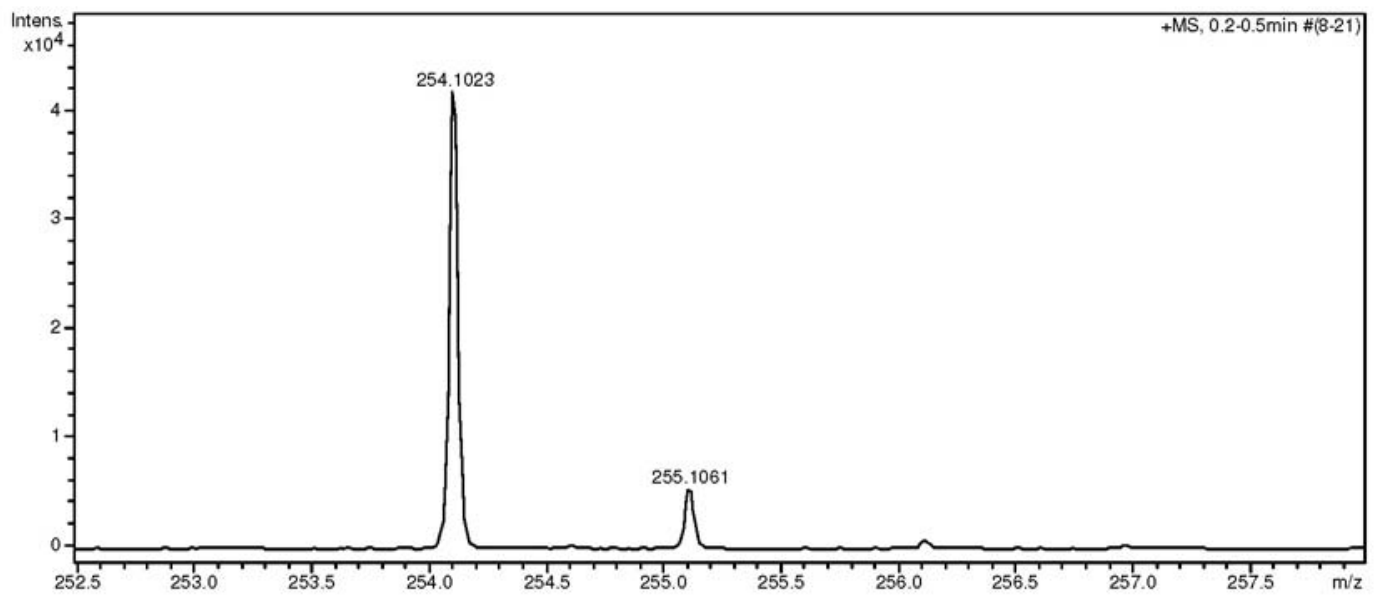

Figure S71. ESI-HRMS spectrum of compound 12. 
2,3-Dihydroxypropyl[2-(hydroxyl(pyridin-4-yl)methyl)] acrylate (13)<smiles>C=C(C(=O)OCC(O)CO)C(O)c1ccncc1</smiles>

${ }^{1} \mathrm{H}$ NMR (MeOD, $\left.300 \mathrm{MHz}\right): \delta 3.35(\mathrm{~s}, 3 \mathrm{H}), 3.49-3.60(\mathrm{~m}, 2 \mathrm{H}), 3.77-3.83(\mathrm{~m}, 1 \mathrm{H}), 4.06-4.21(\mathrm{~m}, 2 \mathrm{H}), 5.61(\mathrm{~s}, 1 \mathrm{H}), 6.08$ (dd, 1H. J 2.5/1.0 Hz), 6.45 (dd, 1H, $J$ 2.0/1.0 Hz), 7.47 (d, 2H, J 6.5 Hz), 8.47 (dd, 2H, $J$ 4.5/1.5 Hz); ${ }^{13} \mathrm{C} \mathrm{NMR}(\mathrm{MeOH}$, $75 \mathrm{MHz}): \delta$ 64.1, 64.6, 71.1, 71.8, 123.7, 127.0, 143.9, 150.0, 167.0; IR (KBr) $v_{\max } / \mathrm{cm}^{-1}: 3363,1716,1269,1161,1115$, 1053; ESI-HRMS $(\mathrm{m} / z)$ calc. for $\mathrm{C}_{12} \mathrm{H}_{15} \mathrm{NO}_{5}\left[(\mathrm{M}+\mathrm{H})^{+}\right] 254.0983$, found 254.1027.

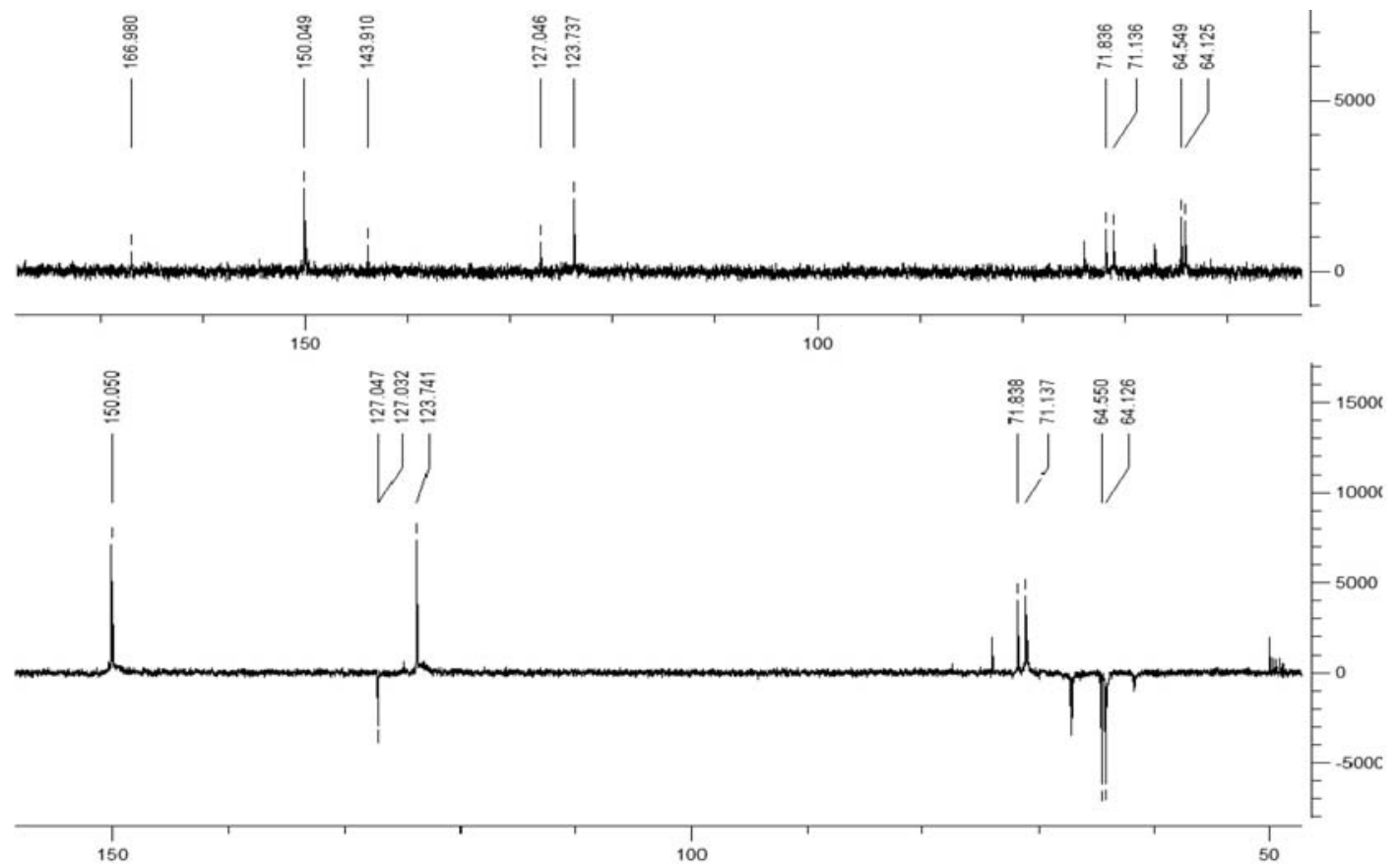

Figure S72. ${ }^{13} \mathrm{C}$ NMR spectrum of compound 13. 


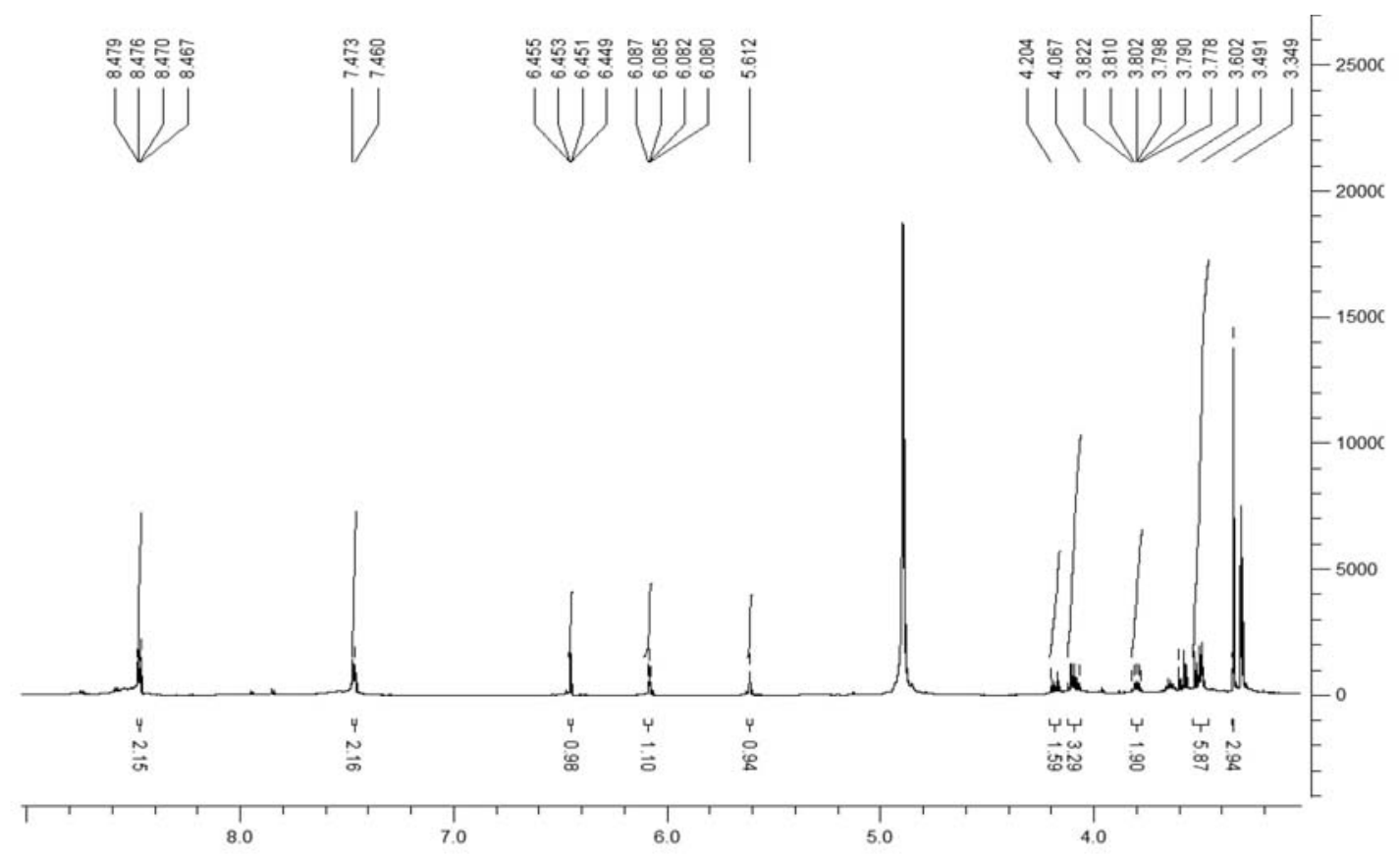

Figure S73. ${ }^{1} \mathrm{H}$ NMR spectrum of compound $\mathbf{1 3}$.

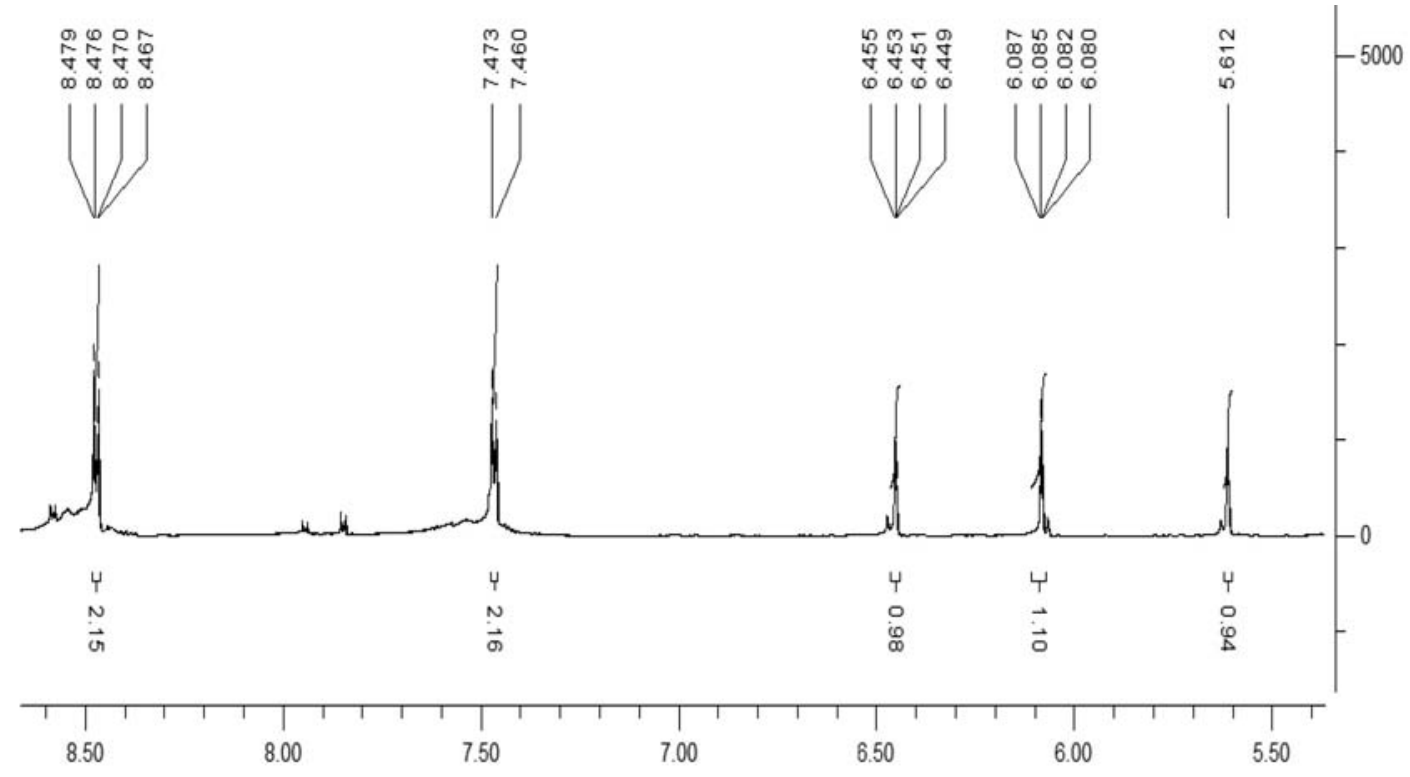

Figure S74. ${ }^{1} \mathrm{H}$ NMR spectrum of compound $\mathbf{1 3}$. 


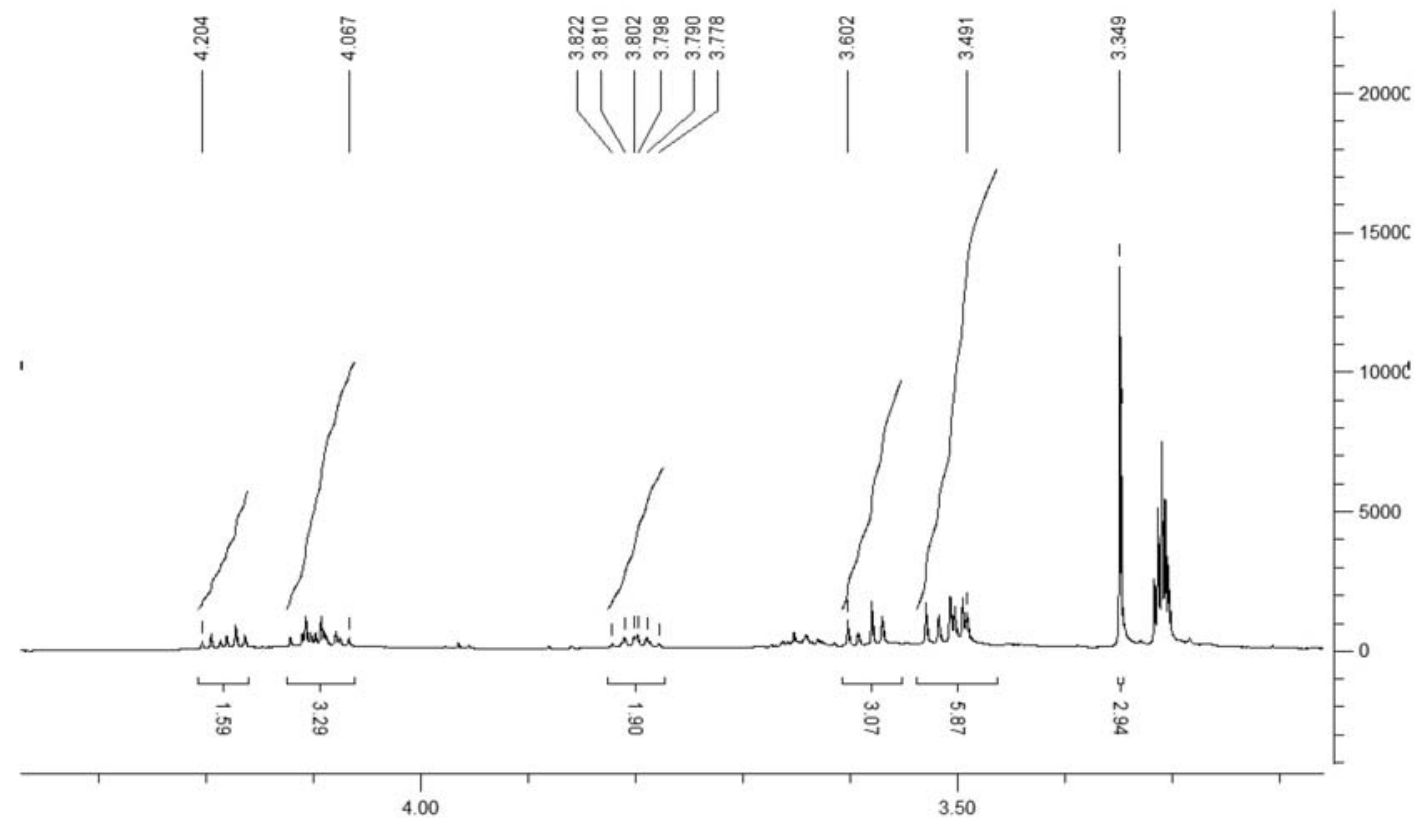

Figure S75. ${ }^{1} \mathrm{H}$ NMR spectrum of compound 13.

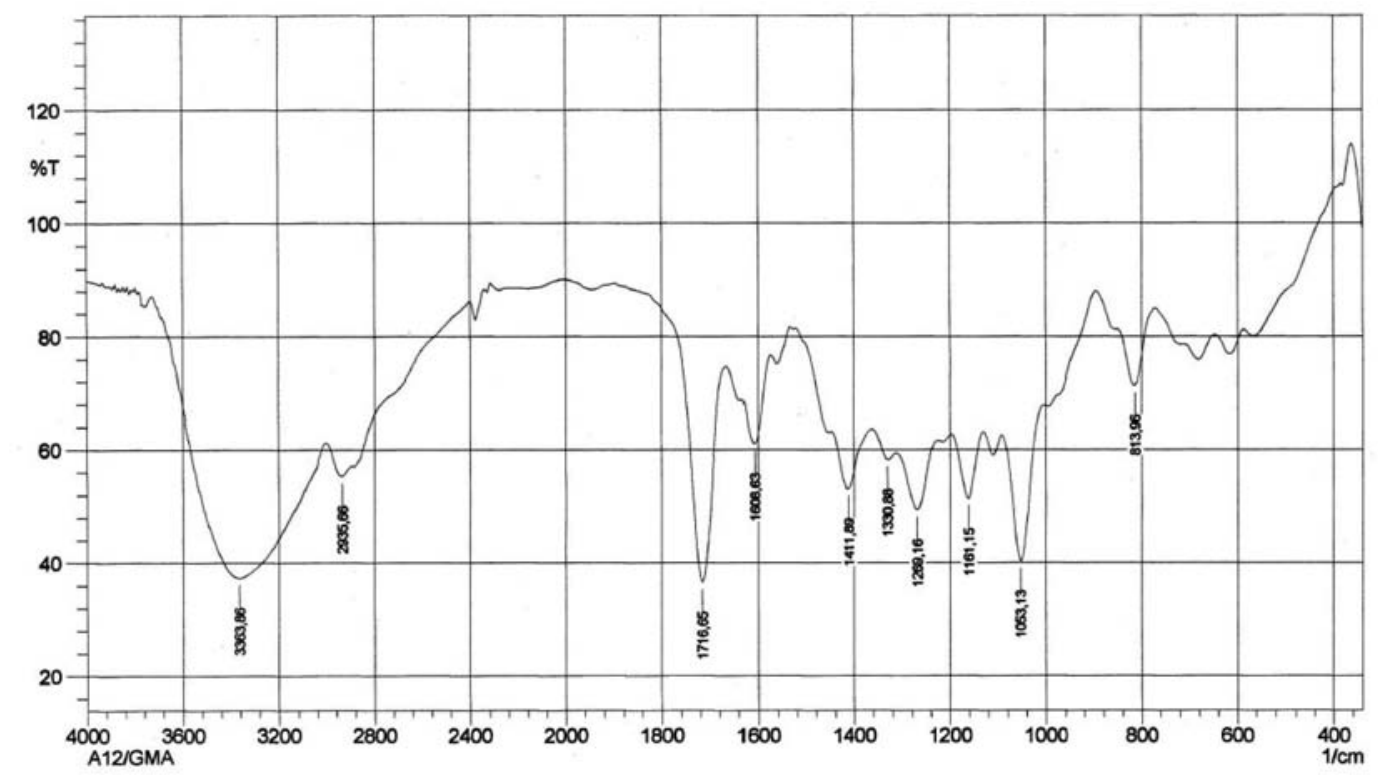

Figure S76. IR spectrum of compound 13. 


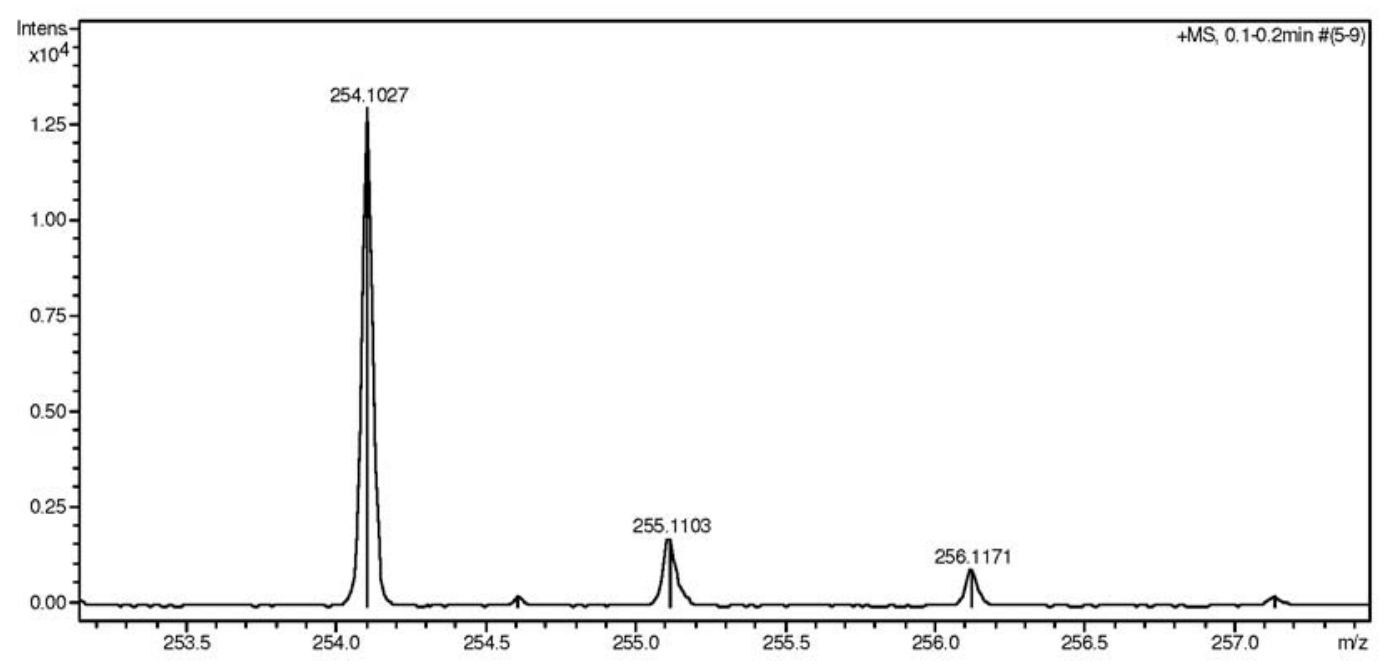

Figure S77. ESI-HRMS spectrum of compound 13. 